\title{
A vanadium-catalysed synthesis of fully substituted pyrroles
}

Patrycja Paciorek, Janusz Szklarzewicz,* Bartosz Trzewik, Dariusz Cież, Wojciech Nitek, Maciej Hodorowicz and Anna Jurowska

Faculty of Chemistry, Jagiellonian University, Gronostajowa 2, 30-387 Kraków, Poland. E-mail: janusz.szklarzewicz@uj.edu.pl

\section{Table of Contents:}

\begin{tabular}{|l|l|}
\hline${ }^{1} \mathrm{H}$ and ${ }^{13} \mathrm{C}$ NMR spectra of the compounds 1-19, A3, A1B1 and A1B4 & S2-S52 \\
\hline Two tautomeric enamine forms of A1B1 and A1B4 & S53 \\
\hline Lists of signal shifts in the compounds 1-19 ${ }^{1}$ H NMR spectra & S54-S55 \\
\hline Infrared spectra of the compounds 1-19, A3, A1B1, A1B4, C1 and C4 & S56-S67 \\
\hline Structures of A1B4, C4 and 4 molecules & S68-S70 \\
\hline
\end{tabular}




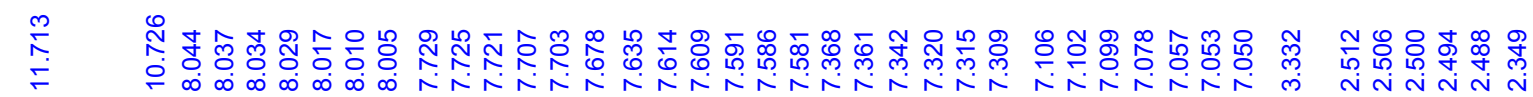

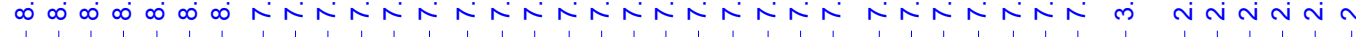

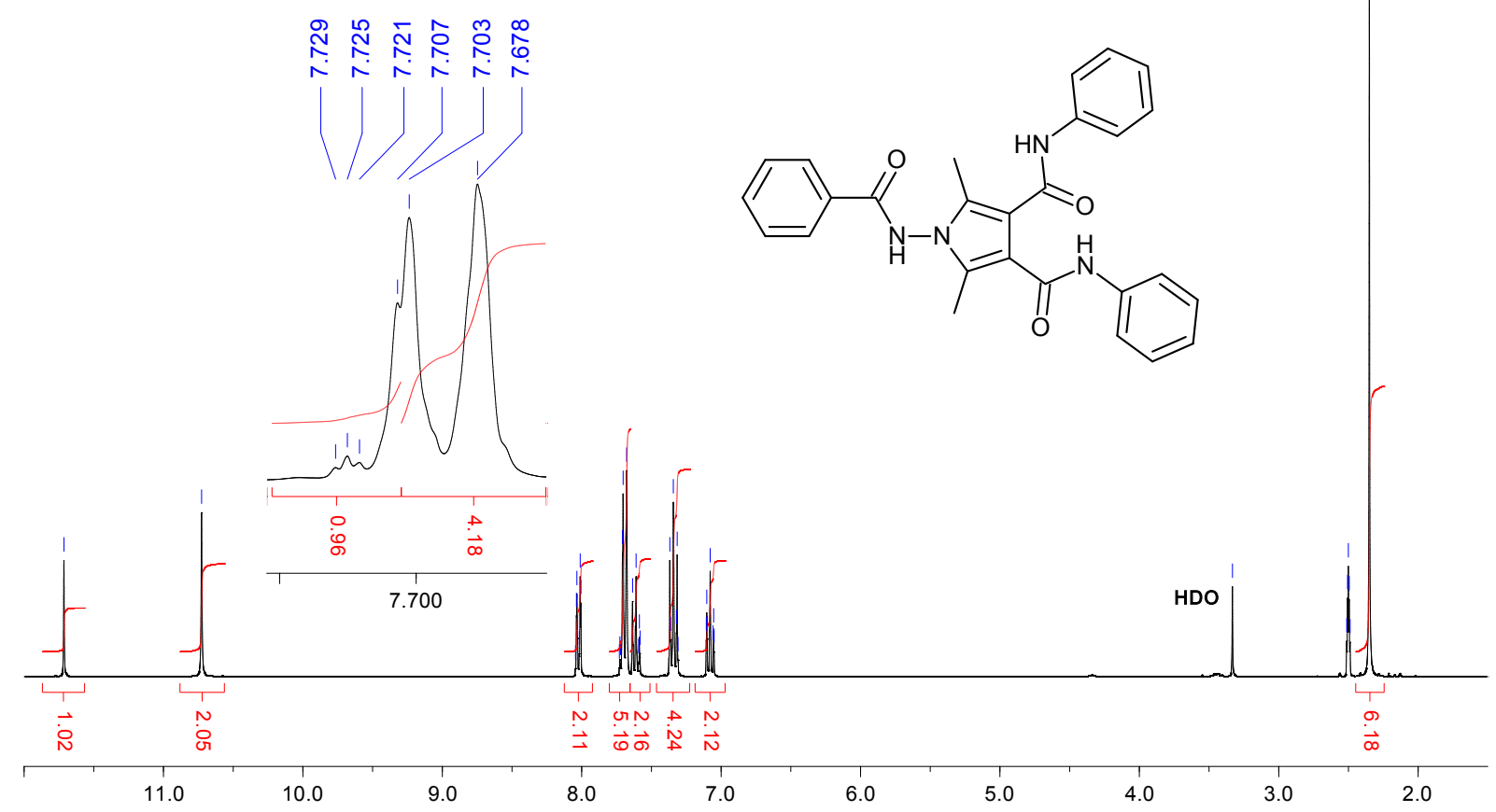

${ }^{1} \mathrm{H}$ NMR $\left(\mathrm{C}_{2} \mathrm{D}_{6} \mathrm{OS}, 300 \mathrm{MHz}\right)$ spectrum of $\mathbf{1}$ 


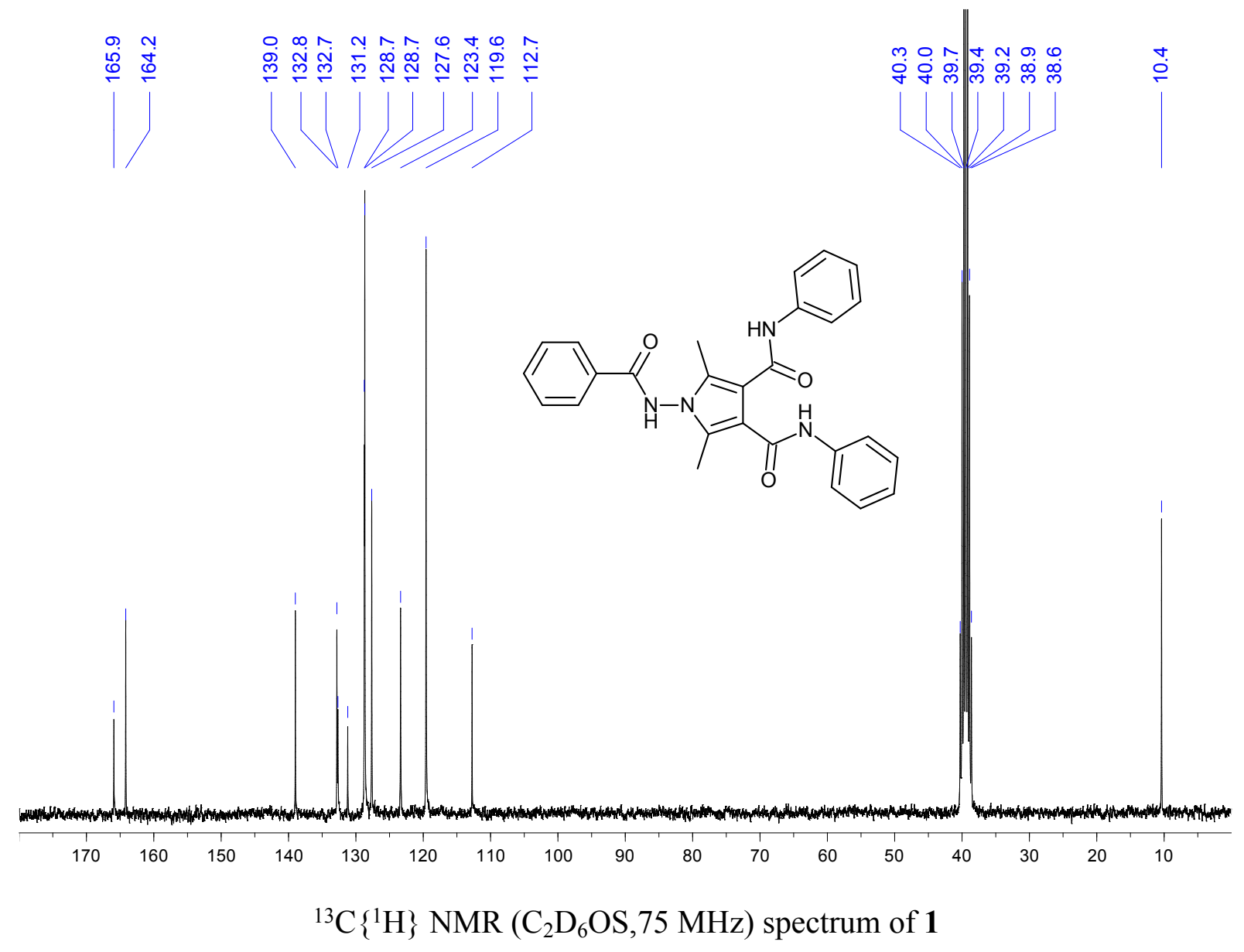




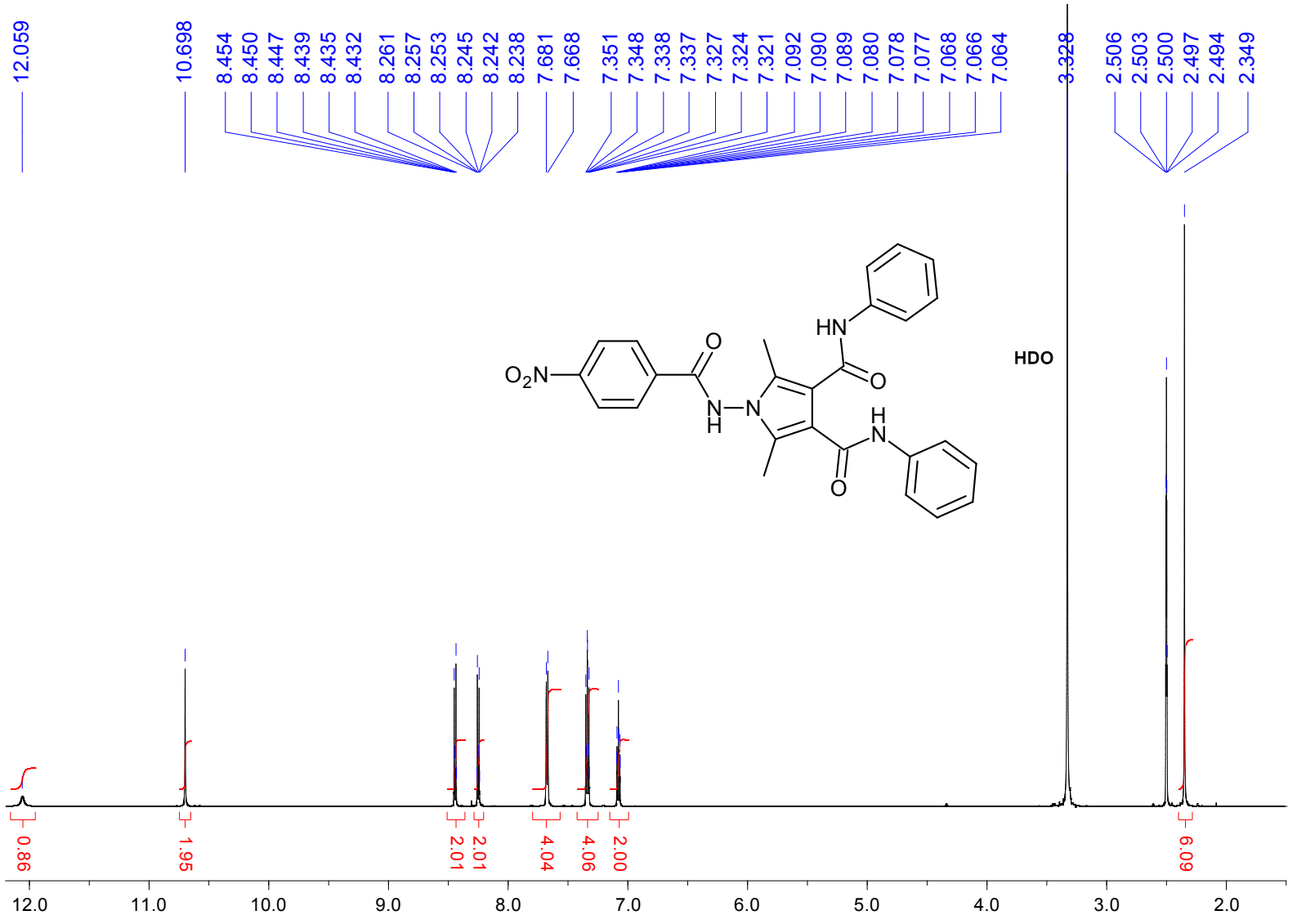

${ }^{1} \mathrm{H}$ NMR $\left(\mathrm{C}_{2} \mathrm{D}_{6} \mathrm{OS}, 300 \mathrm{MHz}\right)$ spectrum of 2 


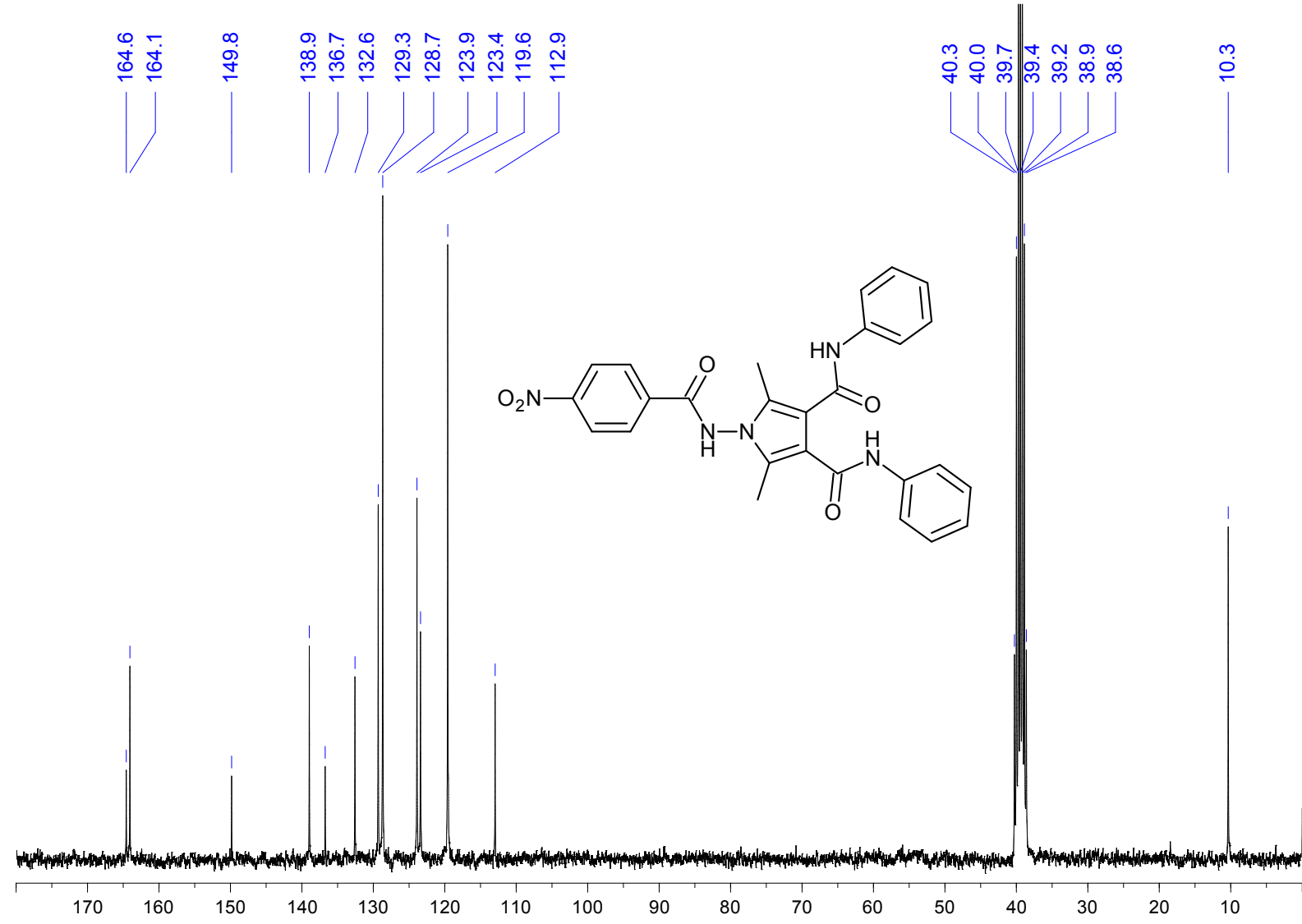

${ }^{13} \mathrm{C}\left\{{ }^{1} \mathrm{H}\right\}$ NMR $\left(\mathrm{C}_{2} \mathrm{D}_{6} \mathrm{OS}, 75 \mathrm{MHz}\right)$ spectrum of 2 


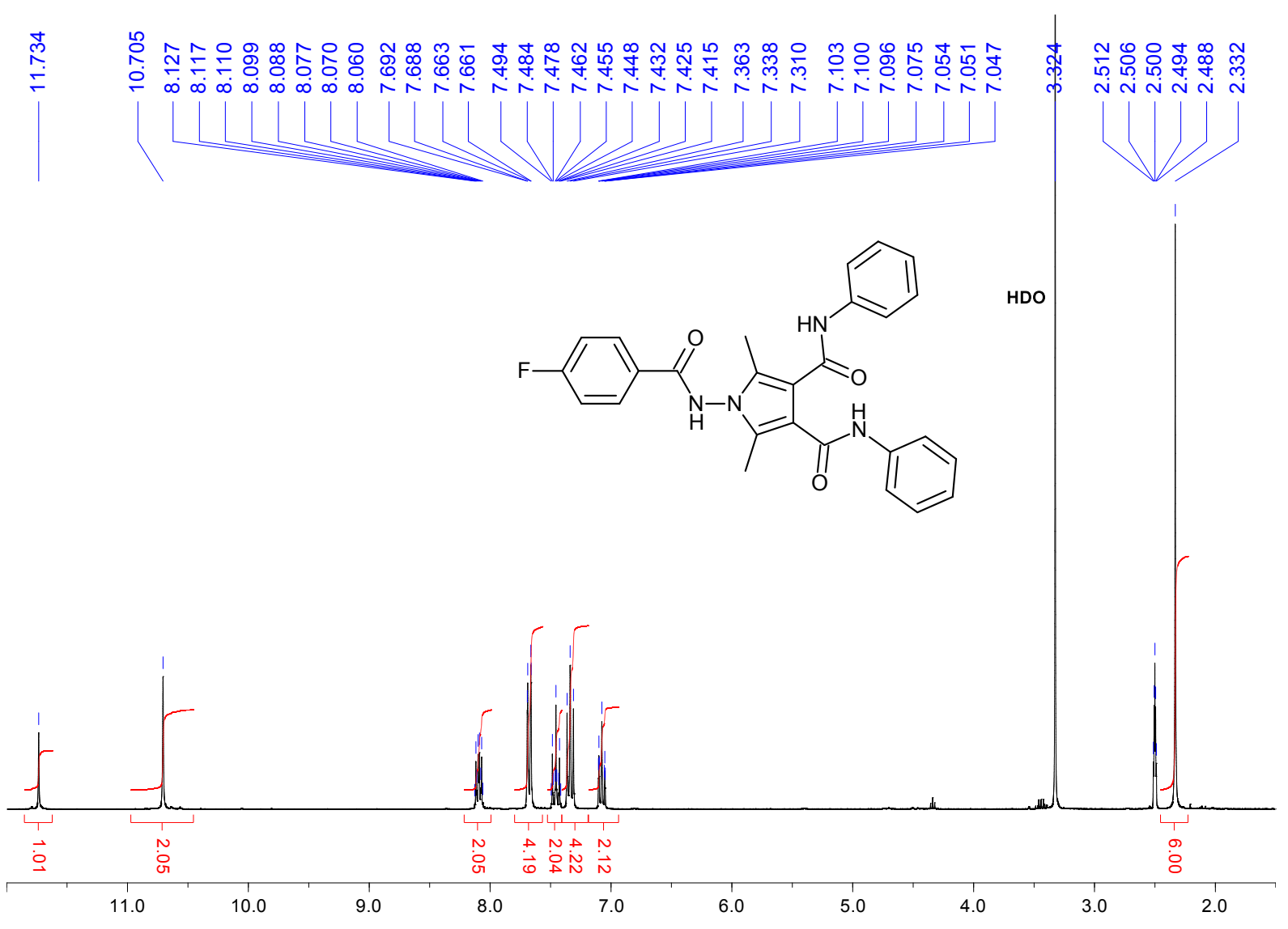

${ }^{1} \mathrm{H}$ NMR $\left(\mathrm{C}_{2} \mathrm{D}_{6} \mathrm{OS}, 300 \mathrm{MHz}\right)$ spectrum of $\mathbf{3}$ 


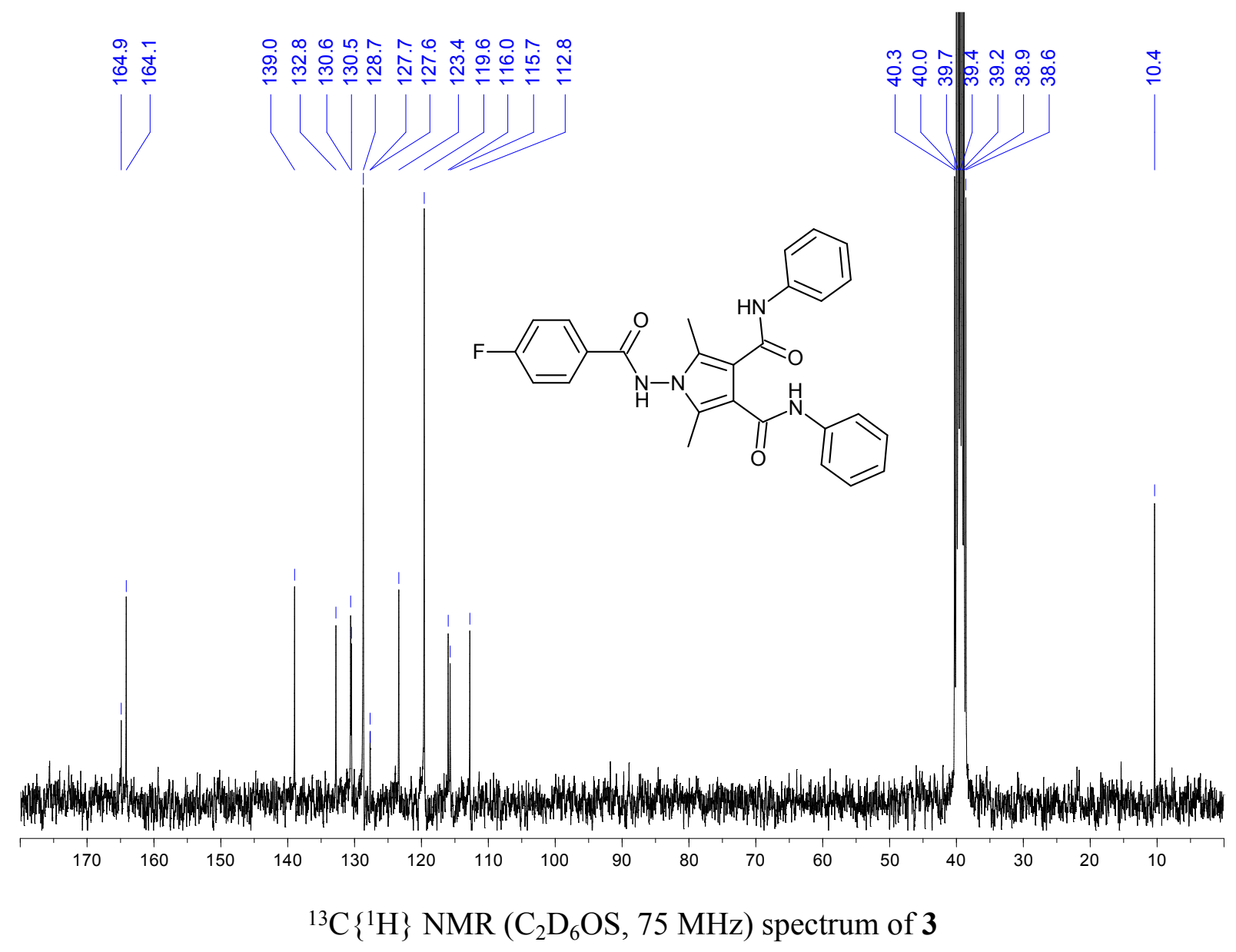




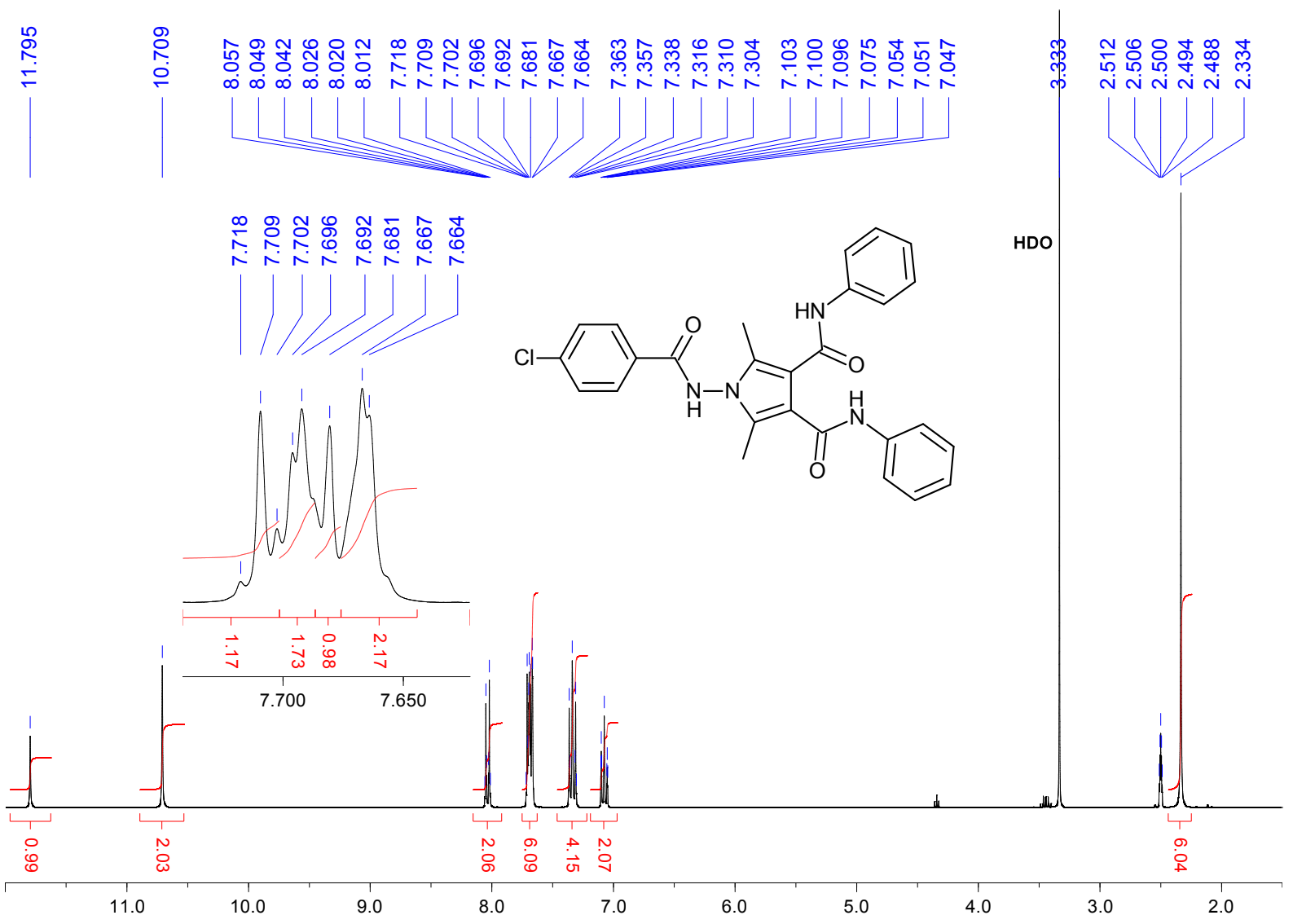

${ }^{1} \mathrm{H}$ NMR $\left(\mathrm{C}_{2} \mathrm{D}_{6} \mathrm{OS}, 300 \mathrm{MHz}\right)$ spectrum of 4 


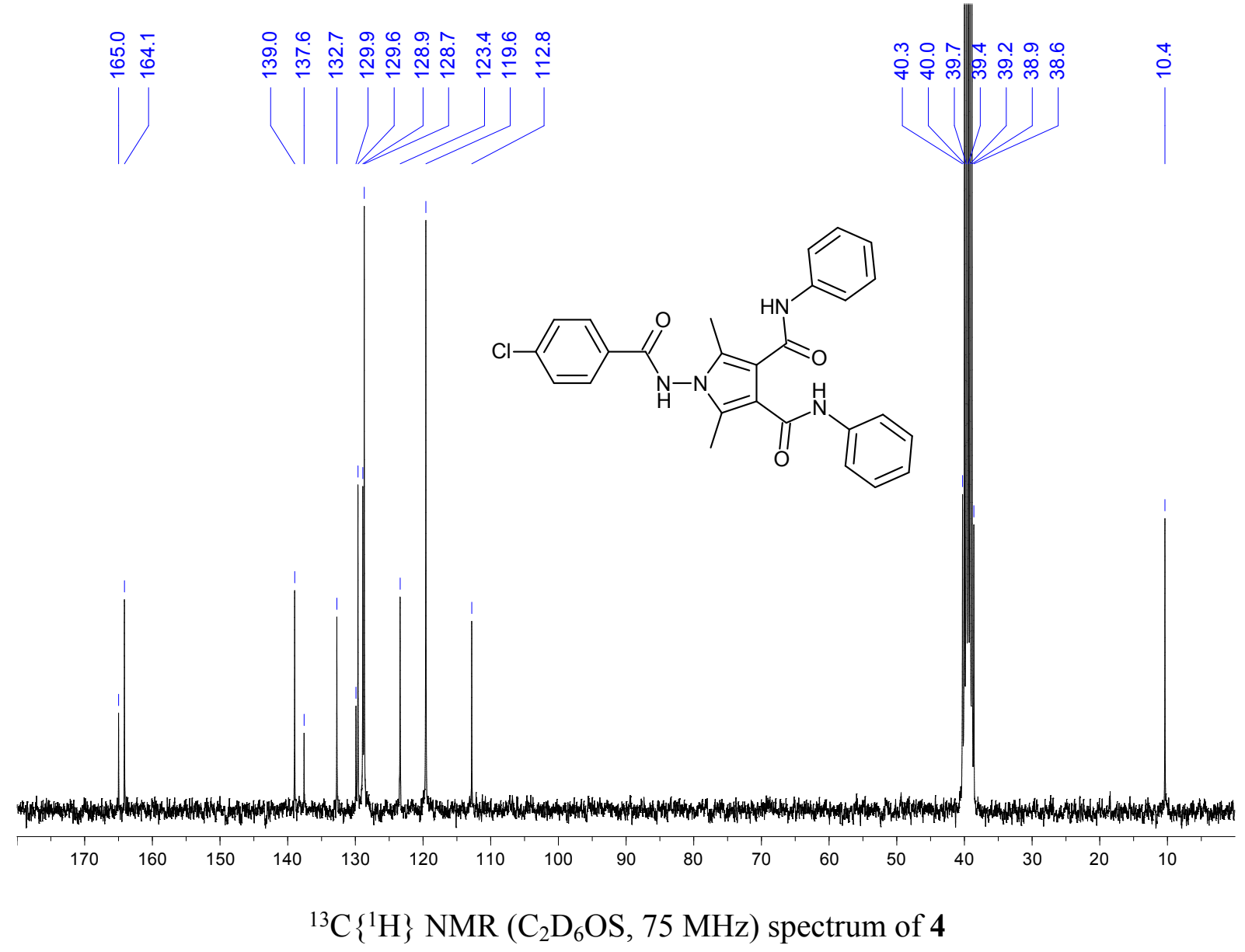




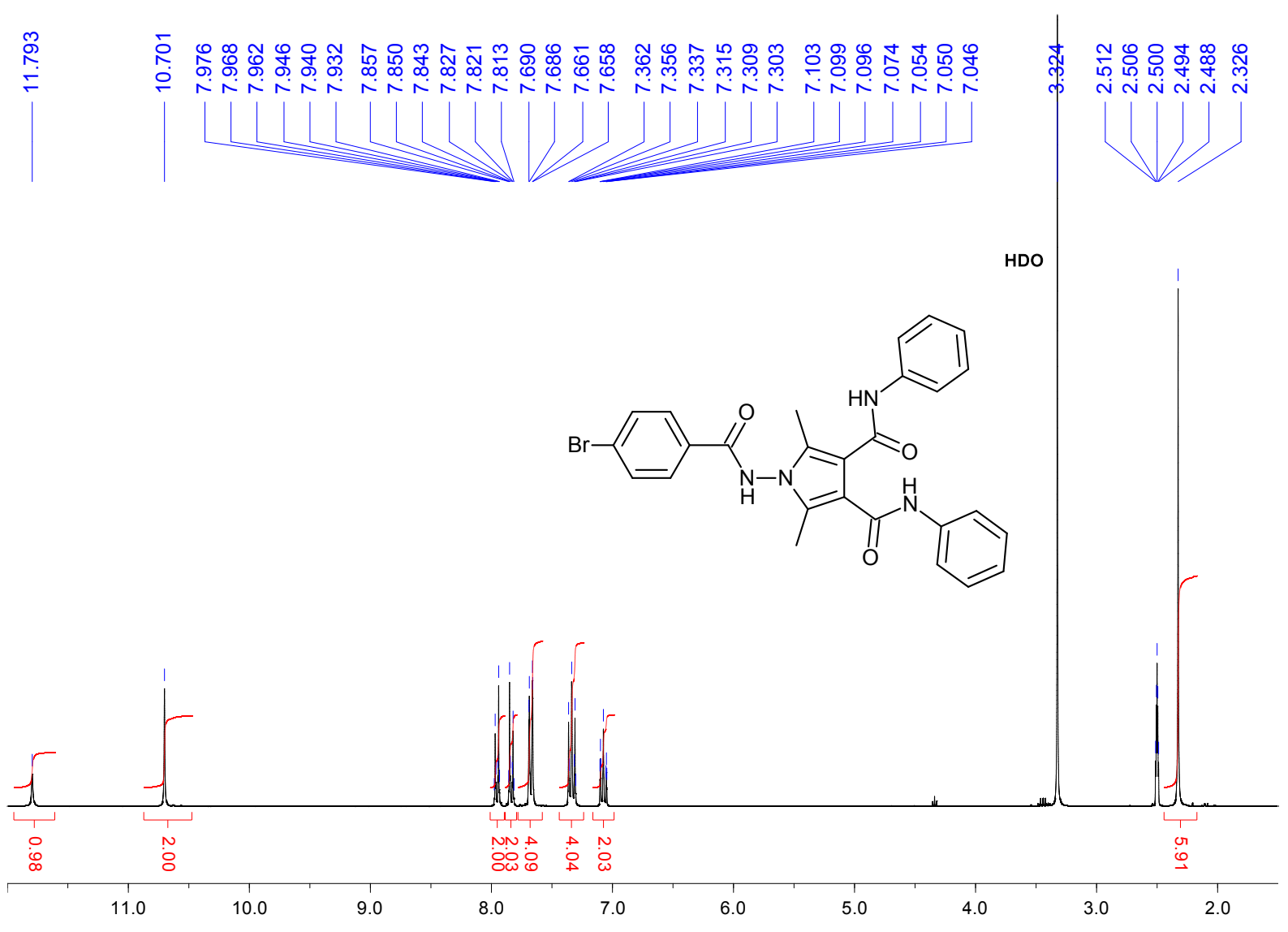

${ }^{1} \mathrm{H}$ NMR $\left(\mathrm{C}_{2} \mathrm{D}_{6} \mathrm{OS}, 300 \mathrm{MHz}\right)$ spectrum of $\mathbf{5}$ 


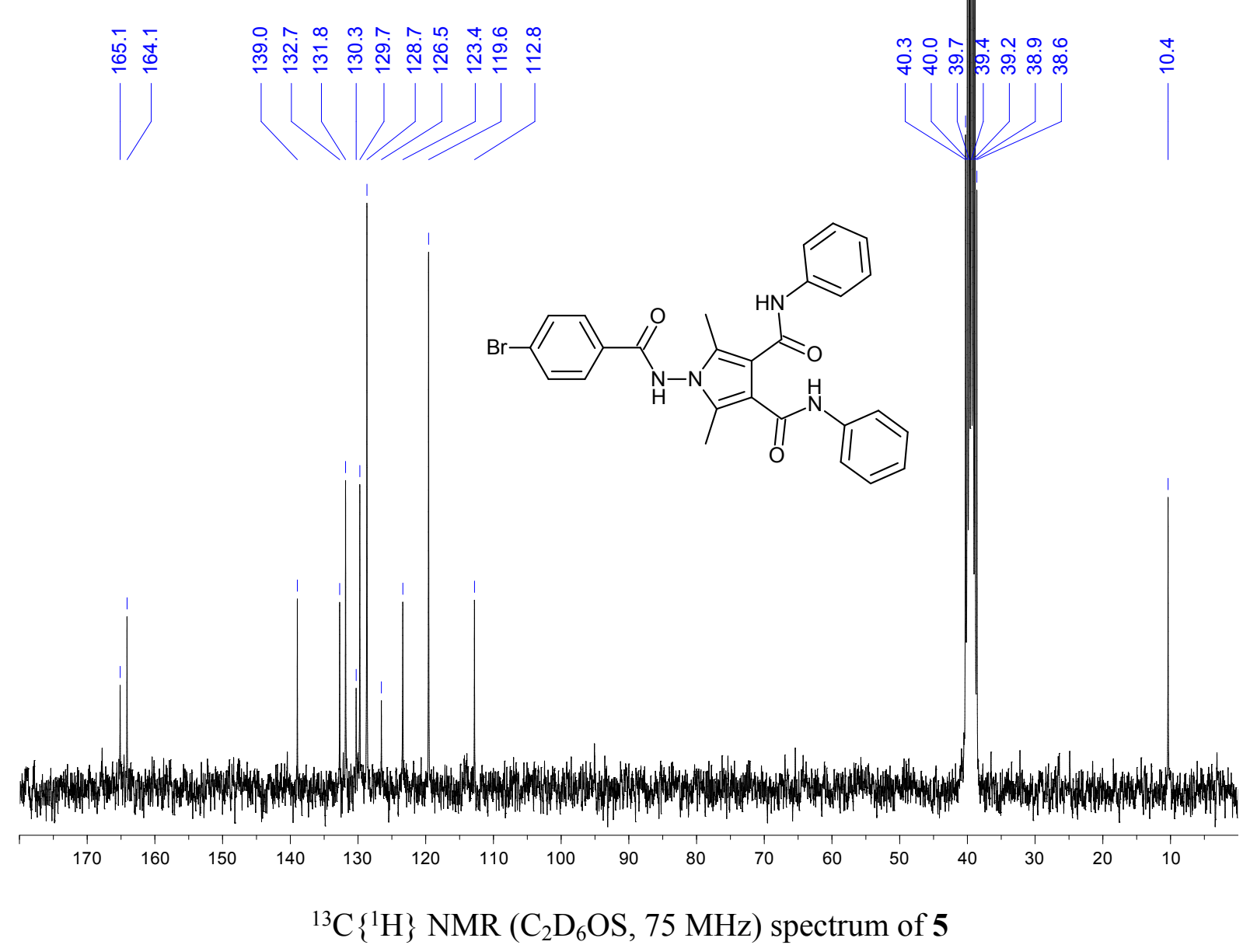




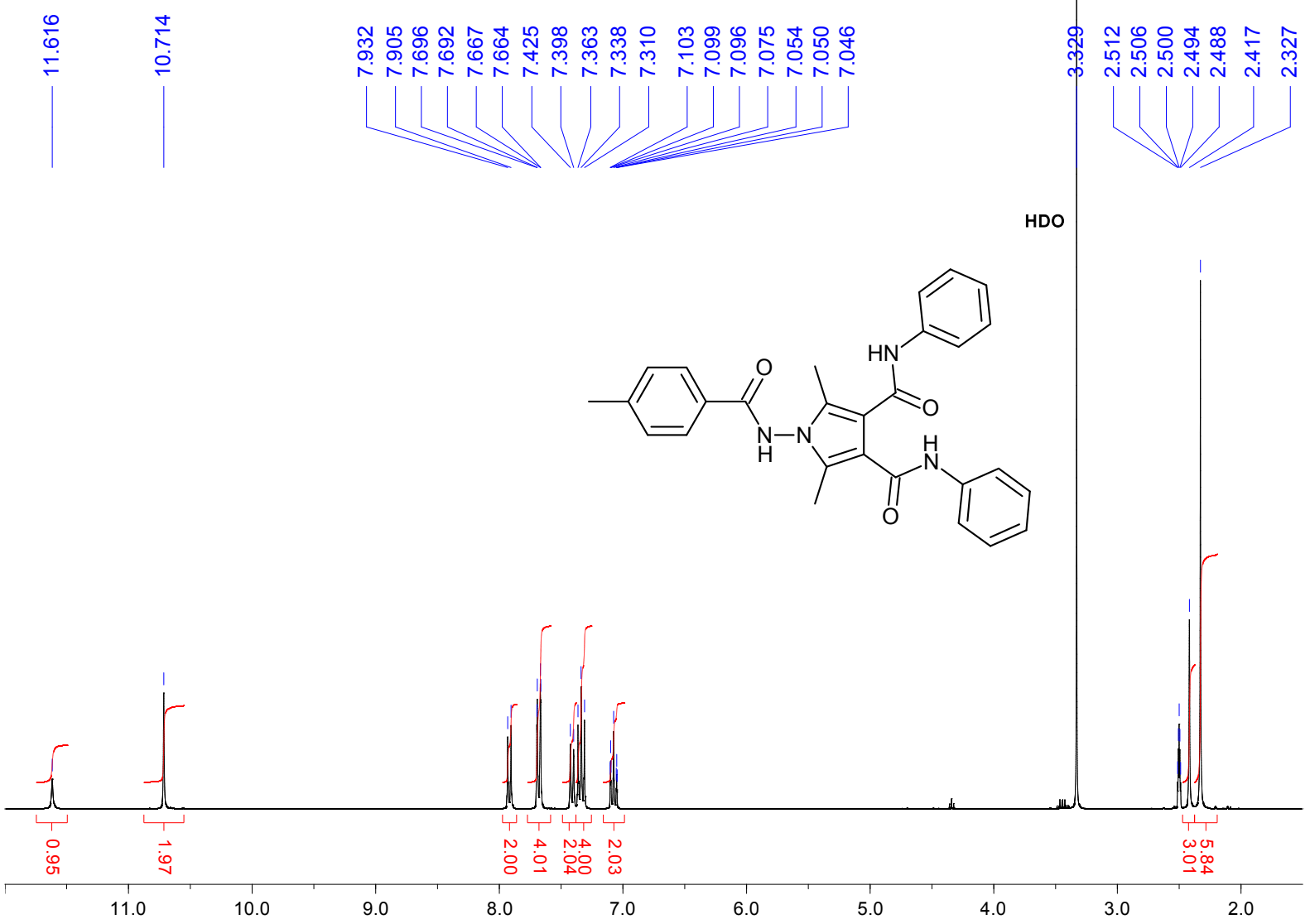

${ }^{1} \mathrm{H}$ NMR $\left(\mathrm{C}_{2} \mathrm{D}_{6} \mathrm{OS}, 300 \mathrm{MHz}\right)$ spectrum of 6 


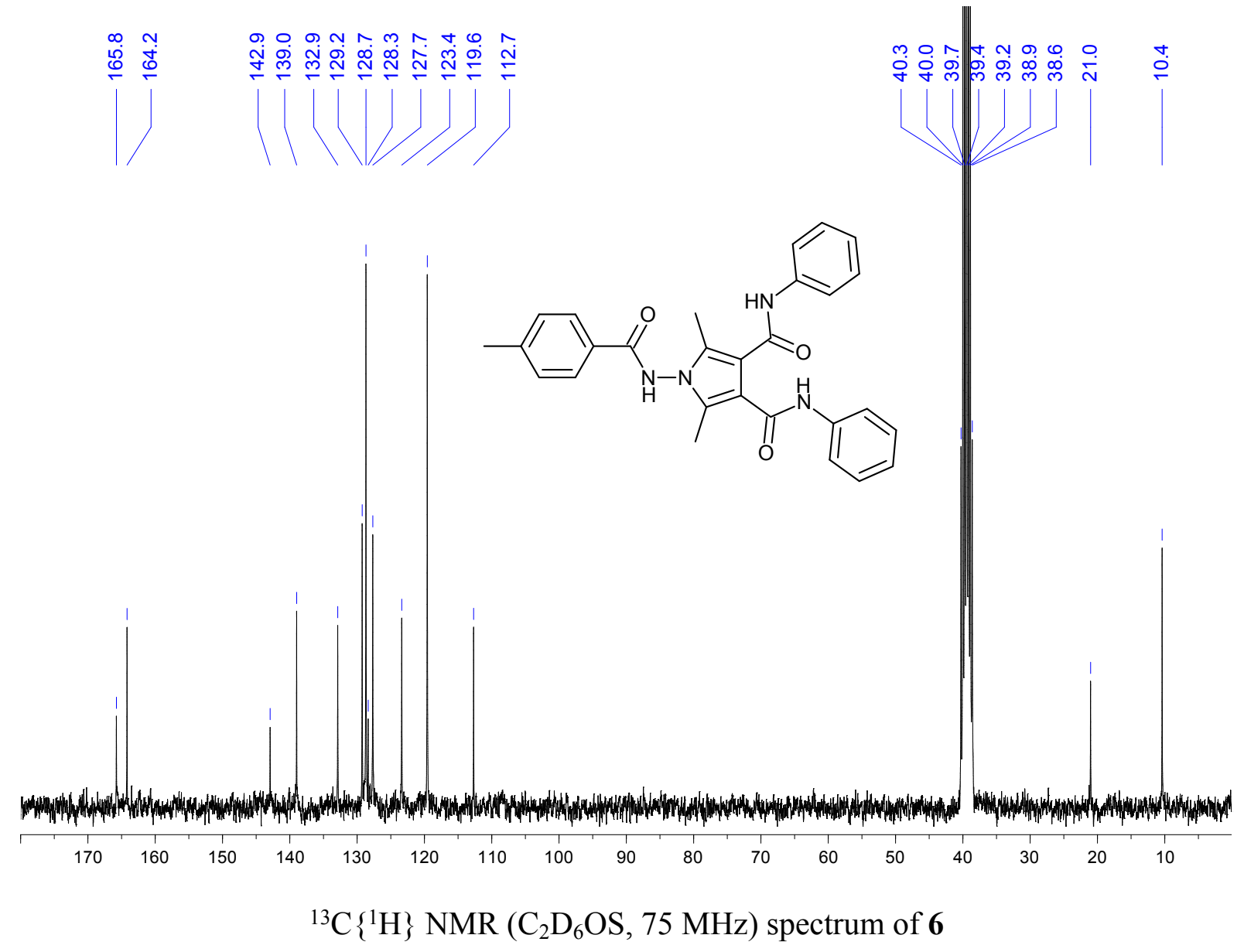




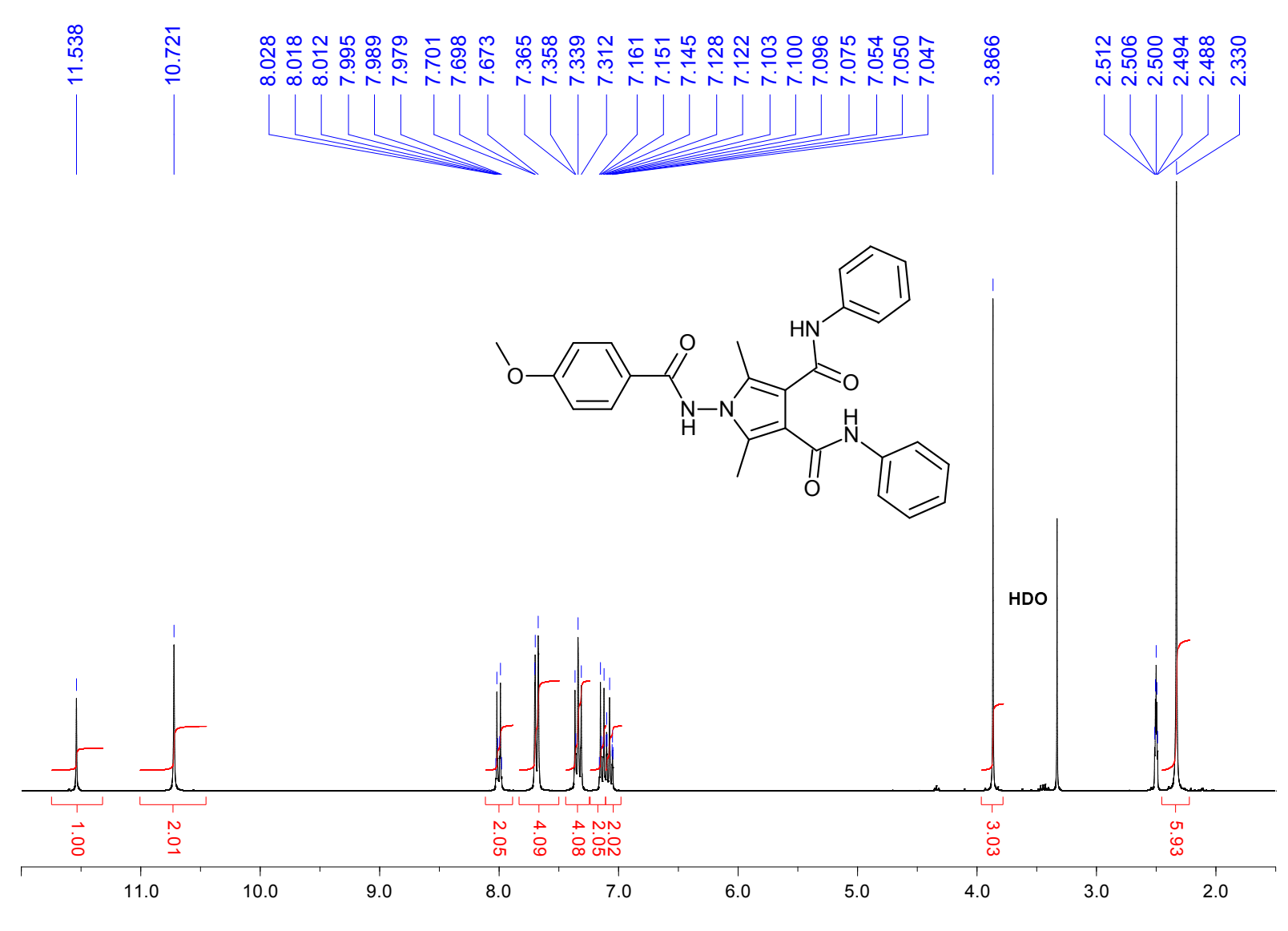

${ }^{1} \mathrm{H}$ NMR $\left(\mathrm{C}_{2} \mathrm{D}_{6} \mathrm{OS}, 300 \mathrm{MHz}\right)$ spectrum of 7 


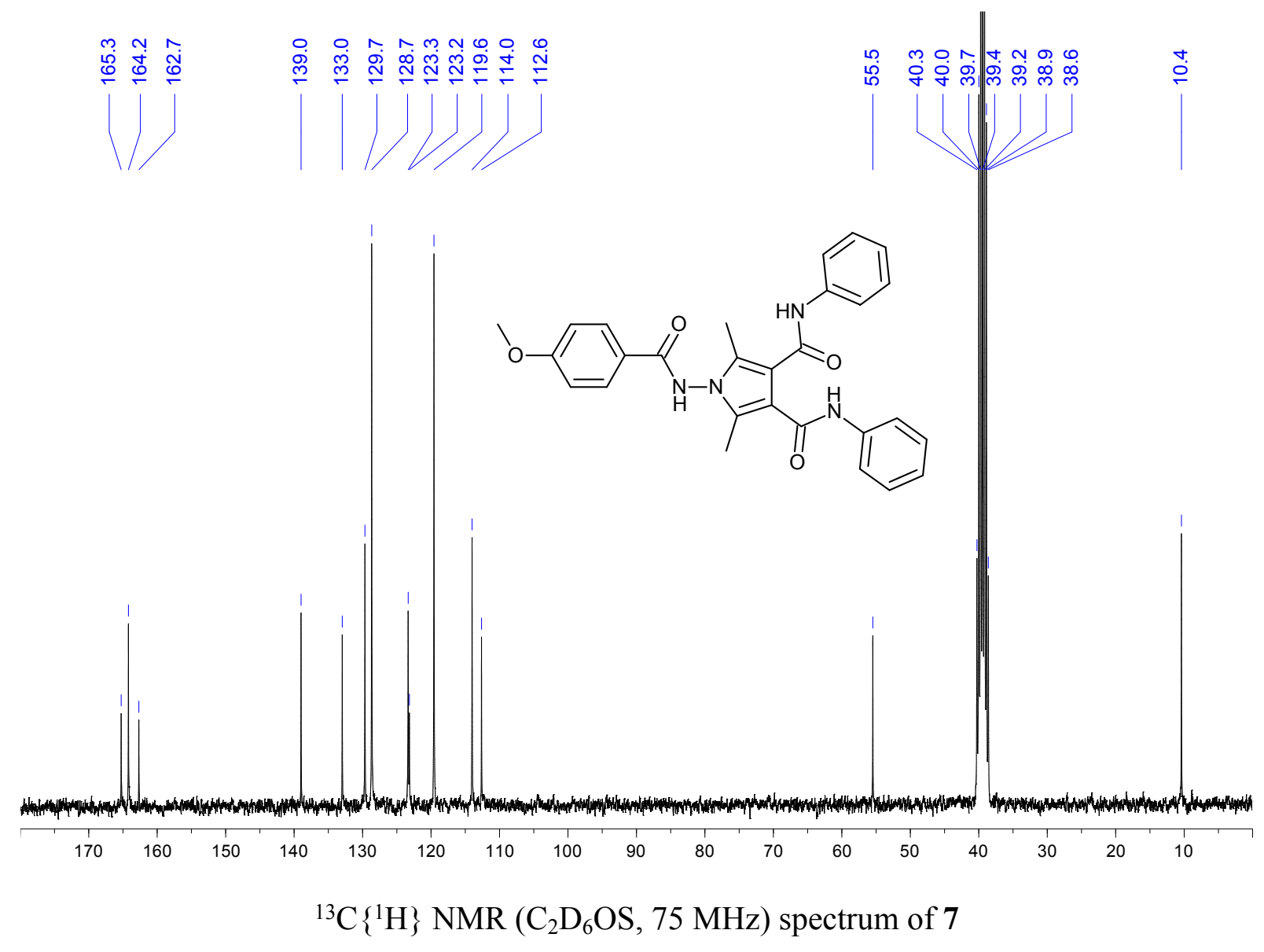




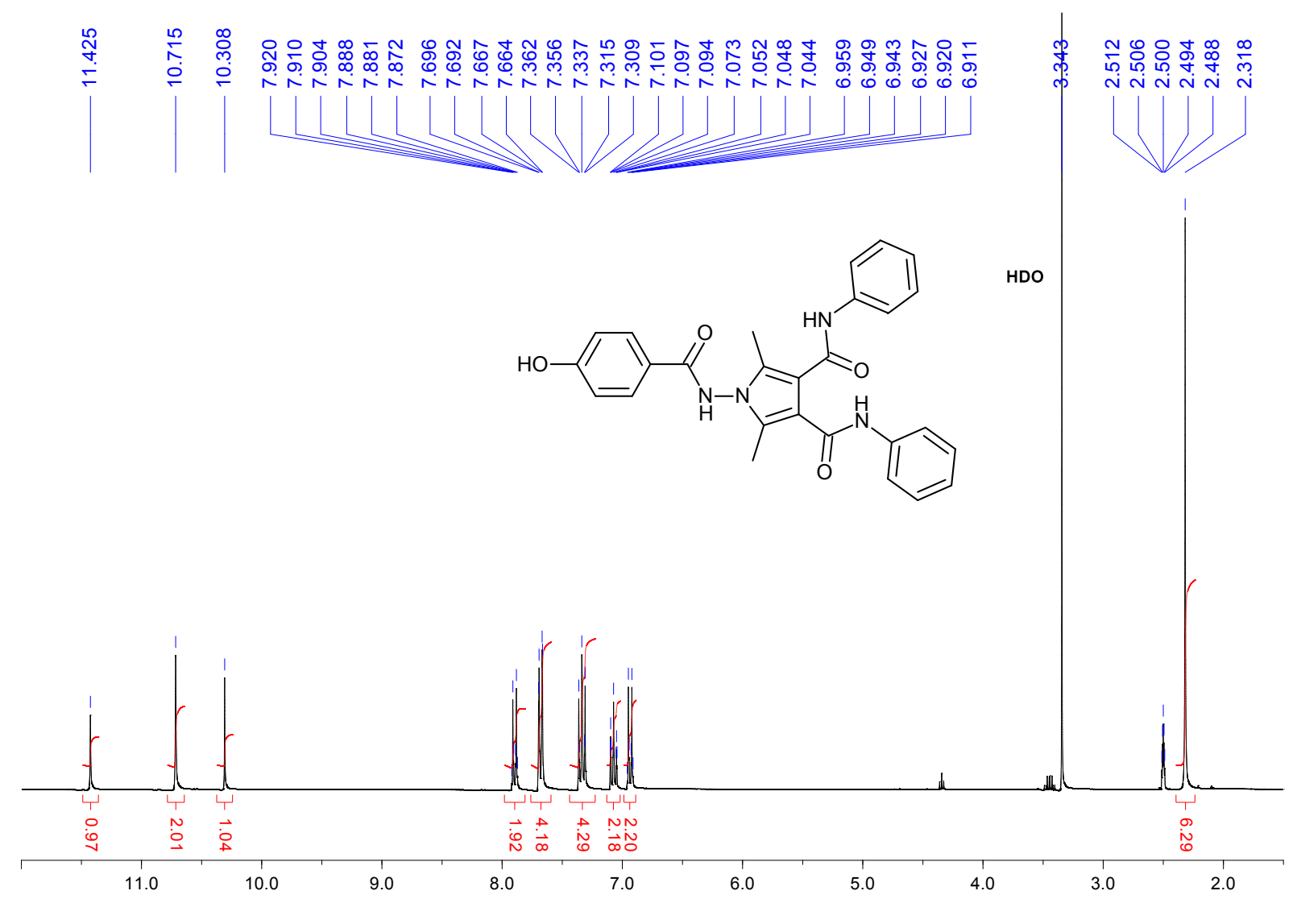

${ }^{1} \mathrm{H}$ NMR $\left(\mathrm{C}_{2} \mathrm{D}_{6} \mathrm{OS}, 300 \mathrm{MHz}\right)$ spectrum of 8 


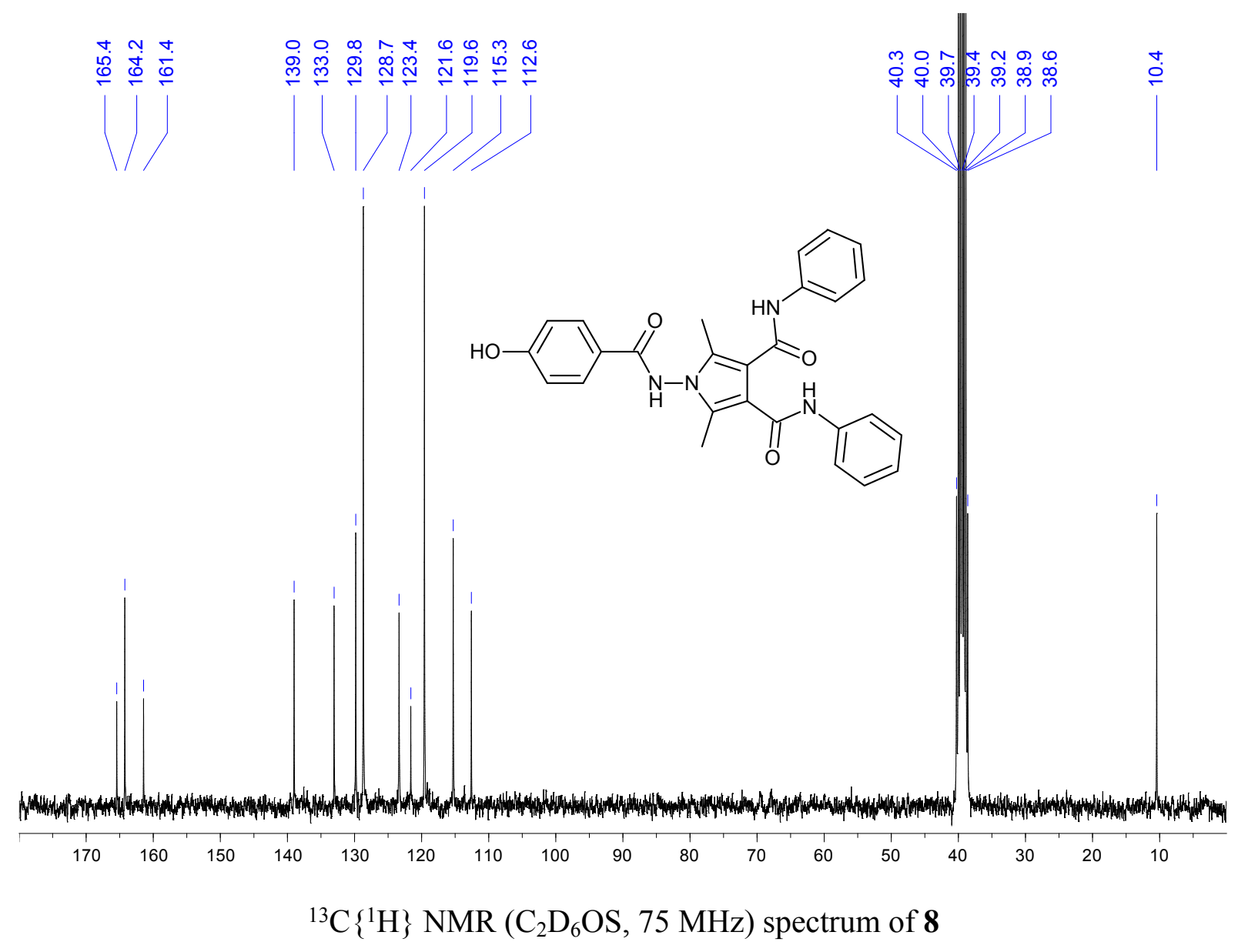




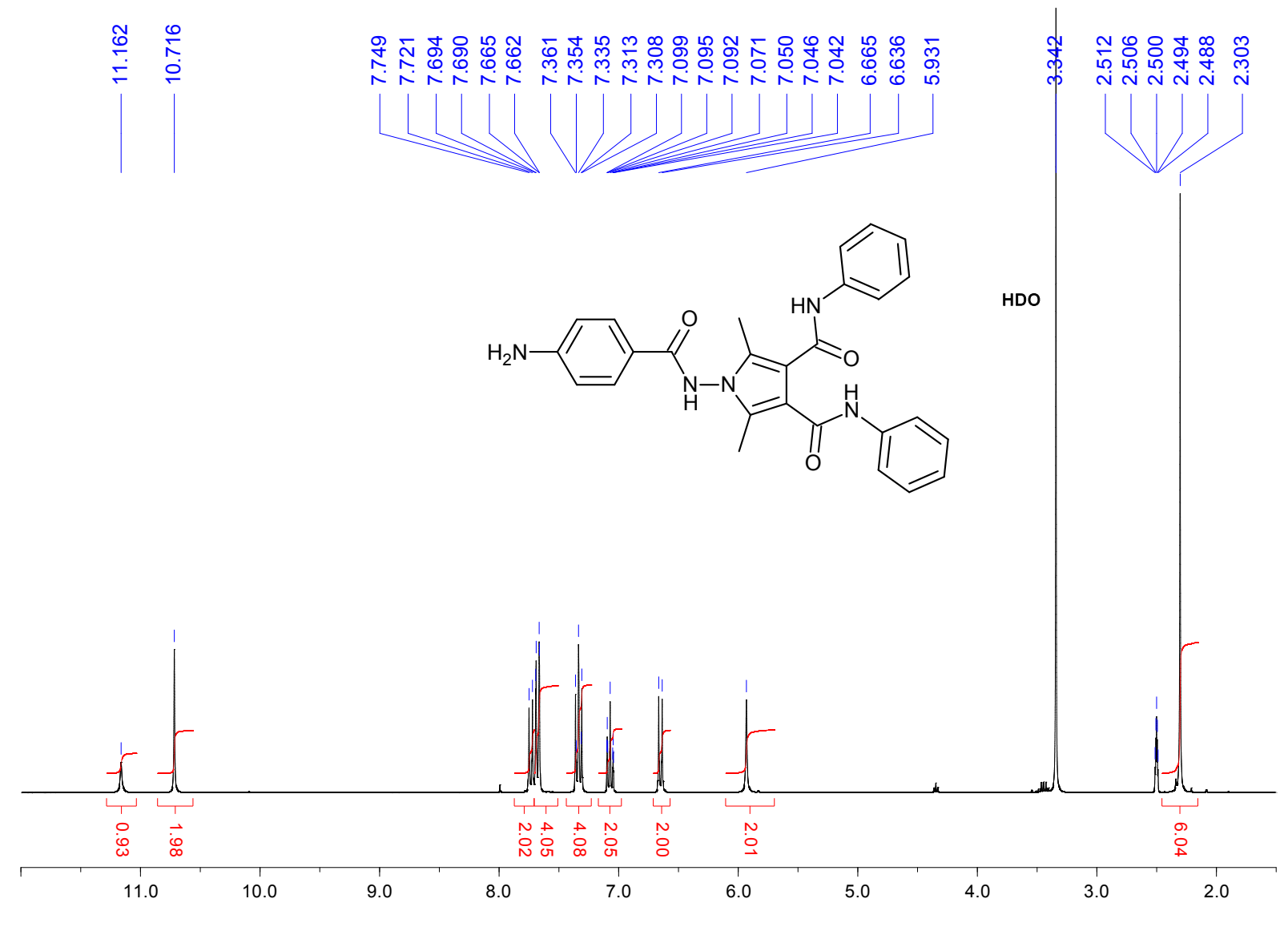

${ }^{1} \mathrm{H}$ NMR $\left(\mathrm{C}_{2} \mathrm{D}_{6} \mathrm{OS}, 300 \mathrm{MHz}\right)$ spectrum of 9 


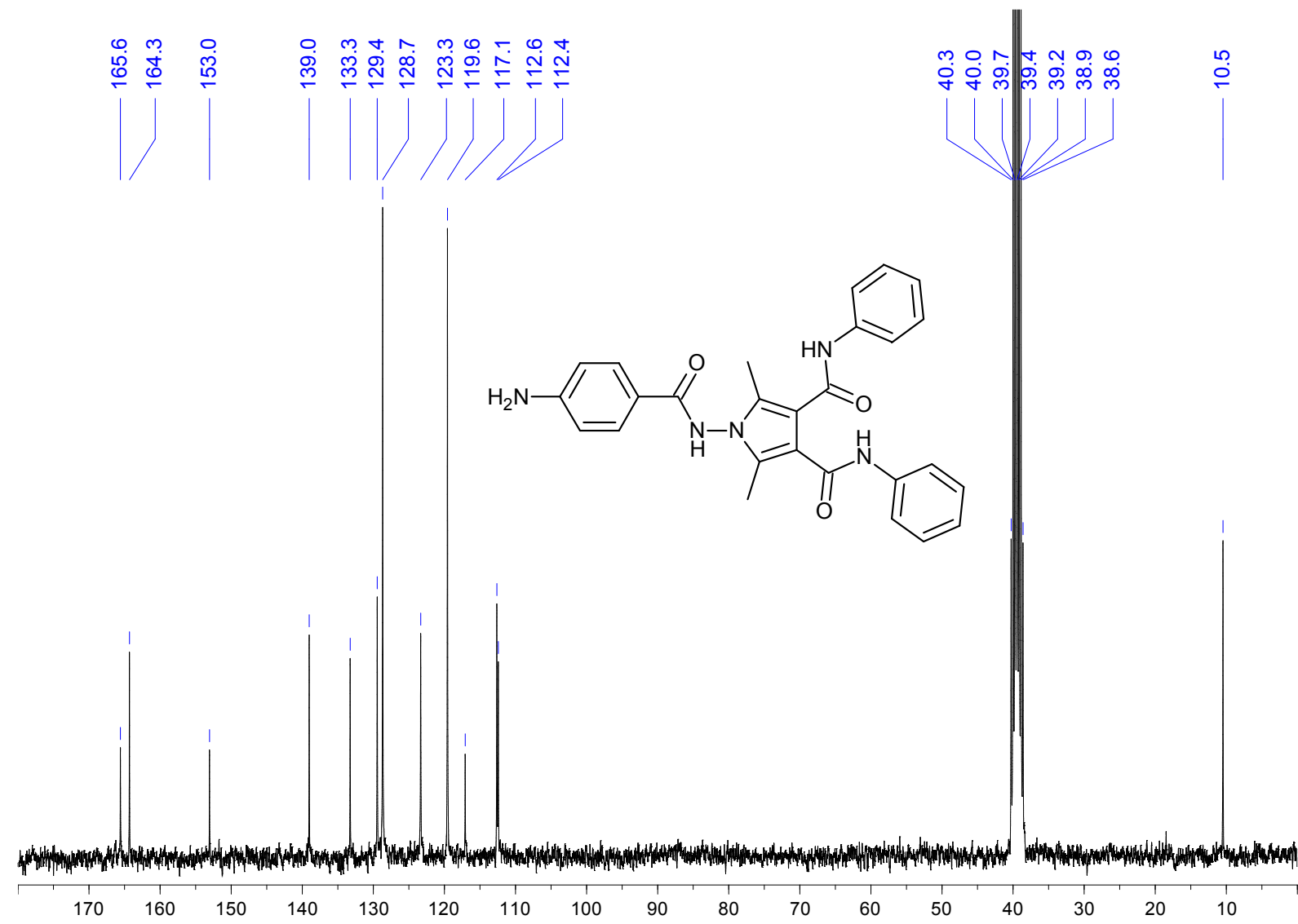

${ }^{13} \mathrm{C}\left\{{ }^{1} \mathrm{H}\right\}$ NMR $\left(\mathrm{C}_{2} \mathrm{D}_{6} \mathrm{OS}, 75 \mathrm{MHz}\right)$ spectrum of 9 


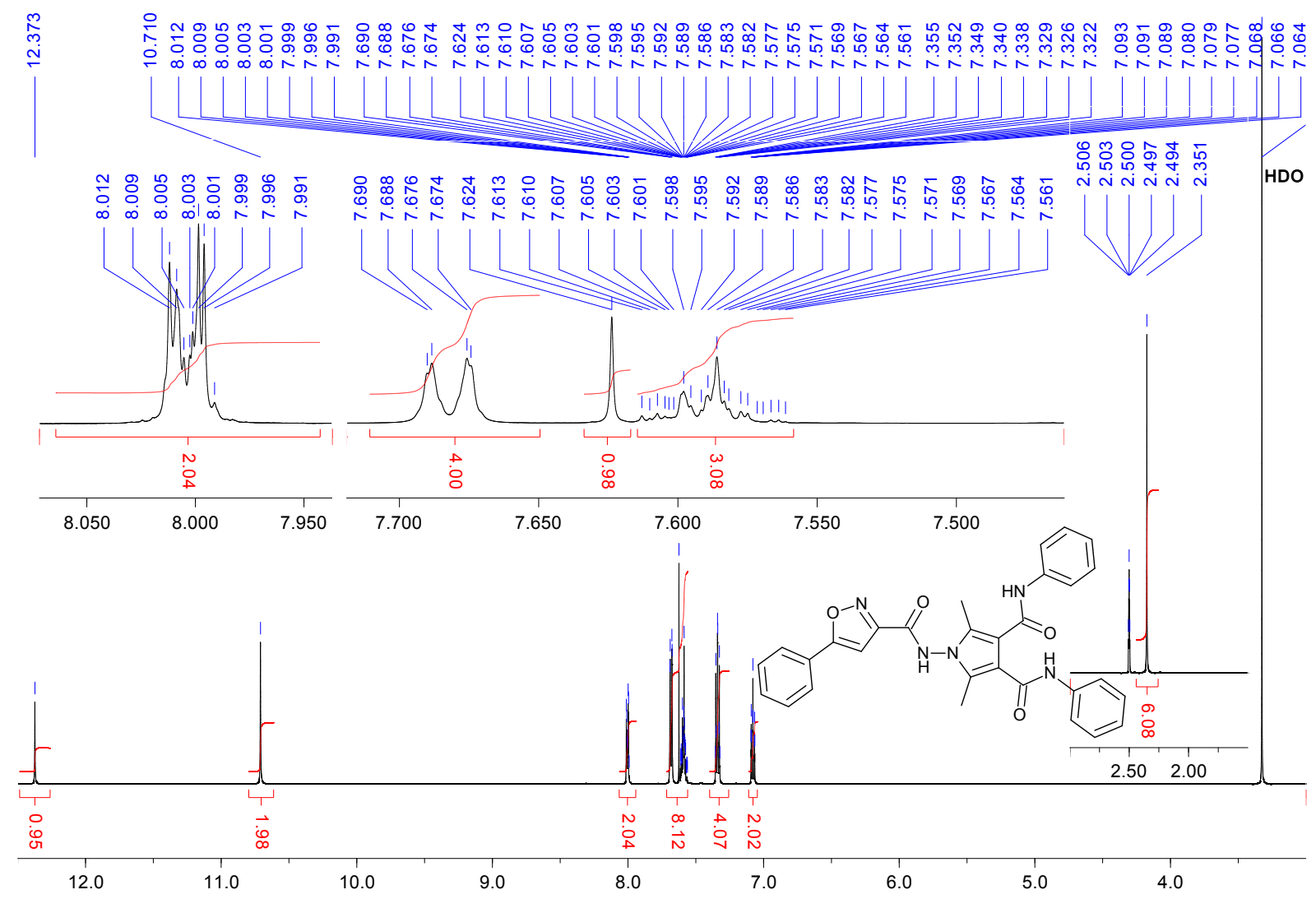

${ }^{1} \mathrm{H}$ NMR $\left(\mathrm{C}_{2} \mathrm{D}_{6} \mathrm{OS}, 300 \mathrm{MHz}\right)$ spectrum of $\mathbf{1 0}$ 


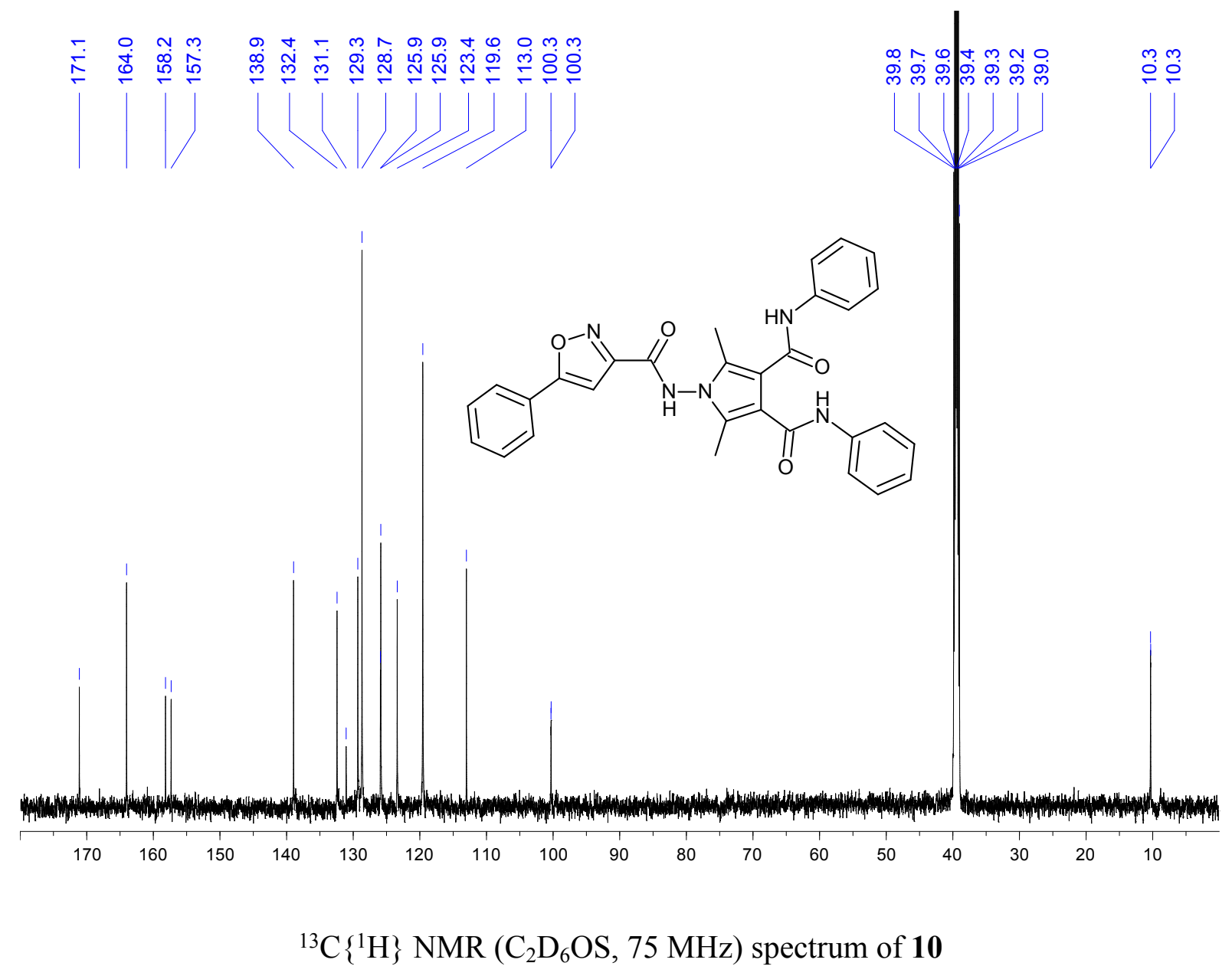




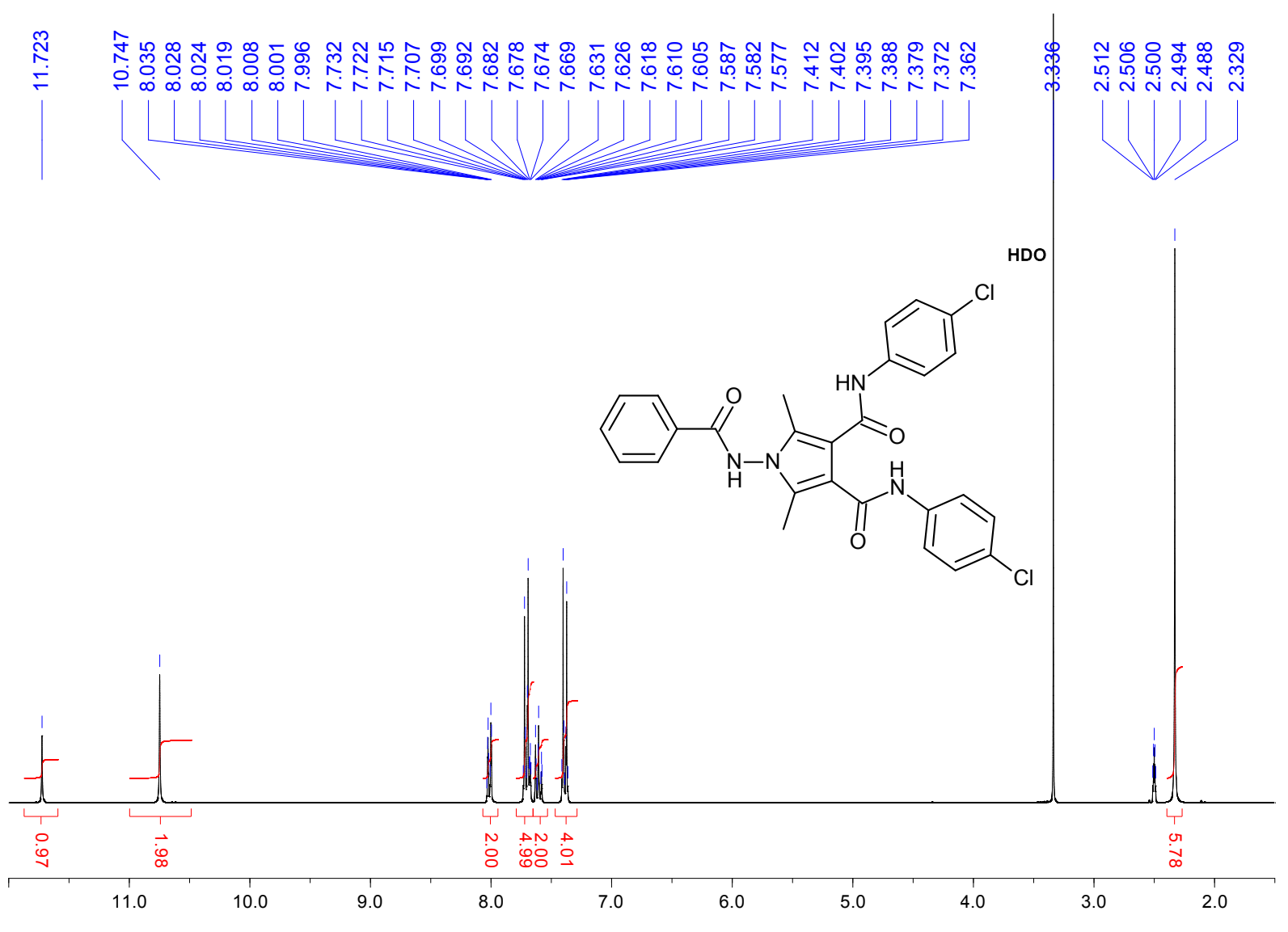

${ }^{1} \mathrm{H}$ NMR $\left(\mathrm{C}_{2} \mathrm{D}_{6} \mathrm{OS}, 300 \mathrm{MHz}\right)$ spectrum of $\mathbf{1 1}$ 


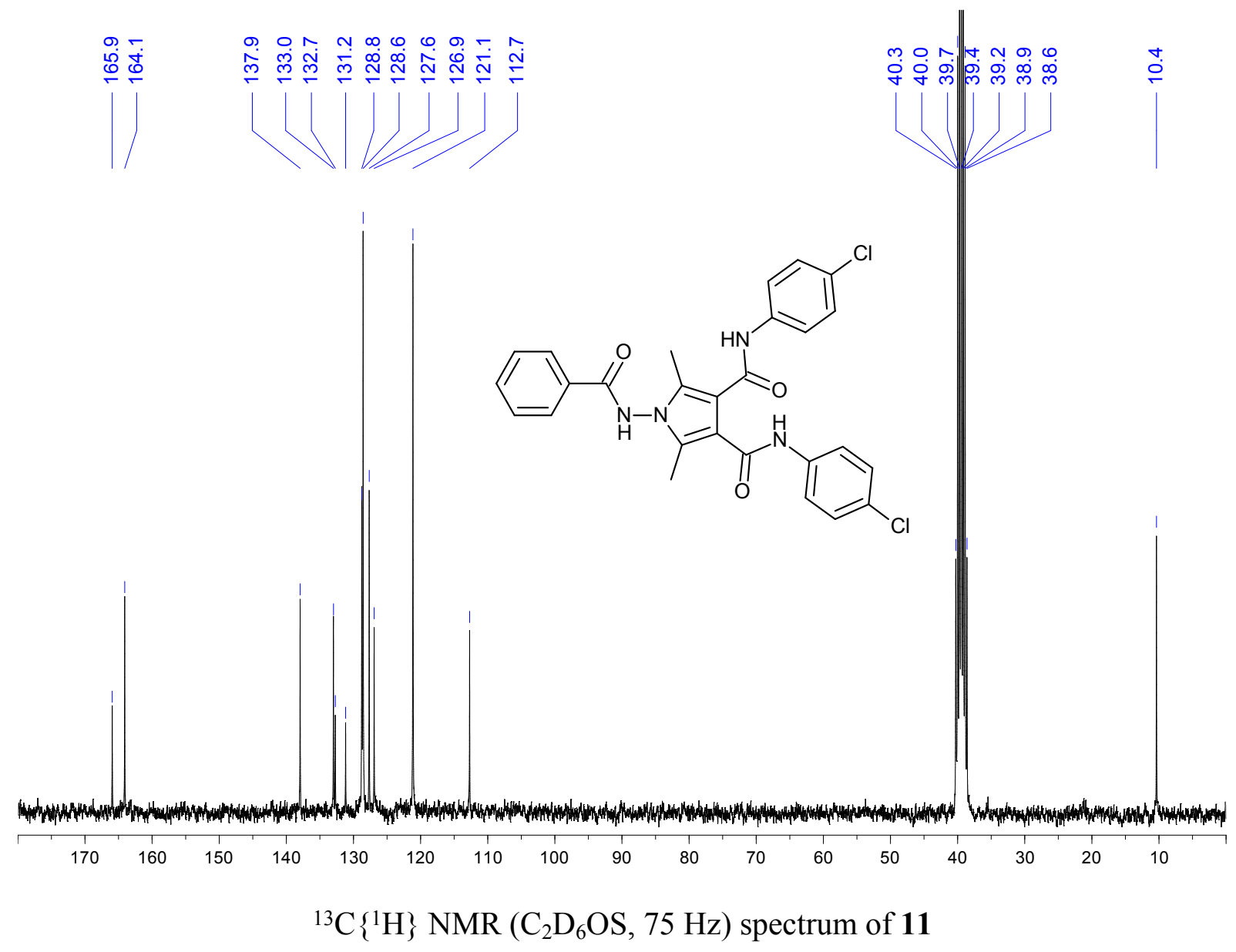




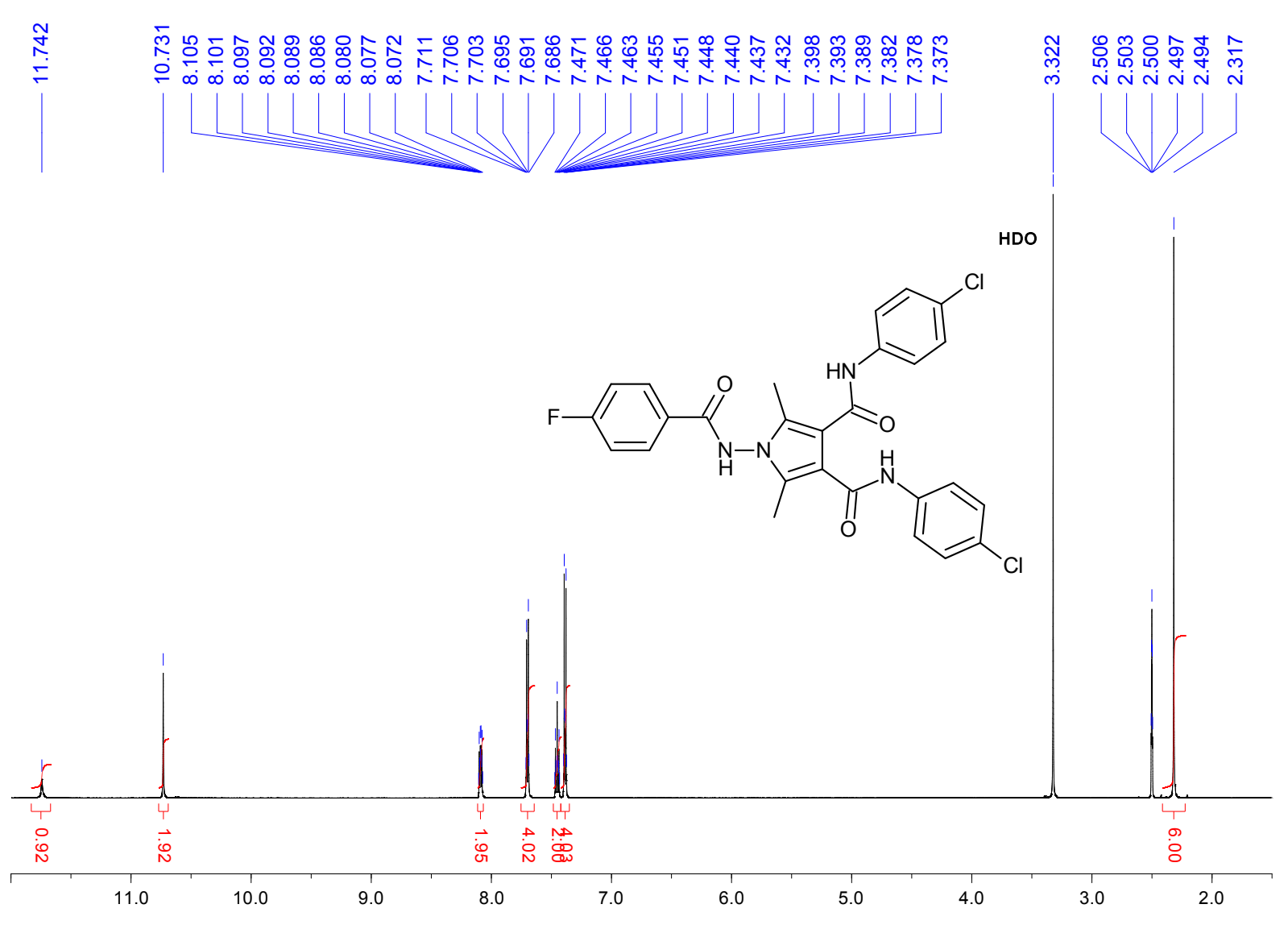

${ }^{1} \mathrm{H}$ NMR $\left(\mathrm{C}_{2} \mathrm{D}_{6} \mathrm{OS}, 600 \mathrm{MHz}\right)$ spectrum of $\mathbf{1 2}$ 


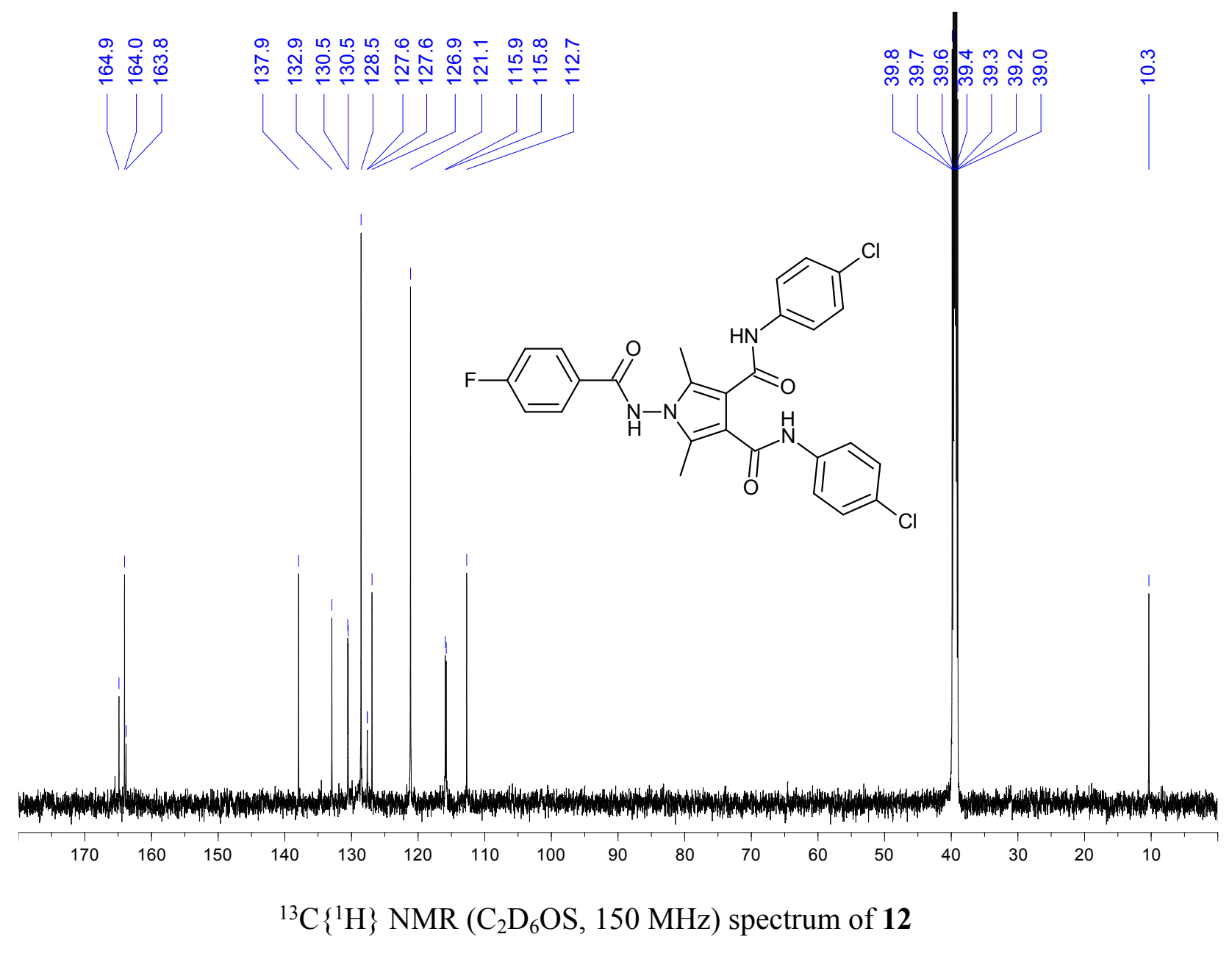




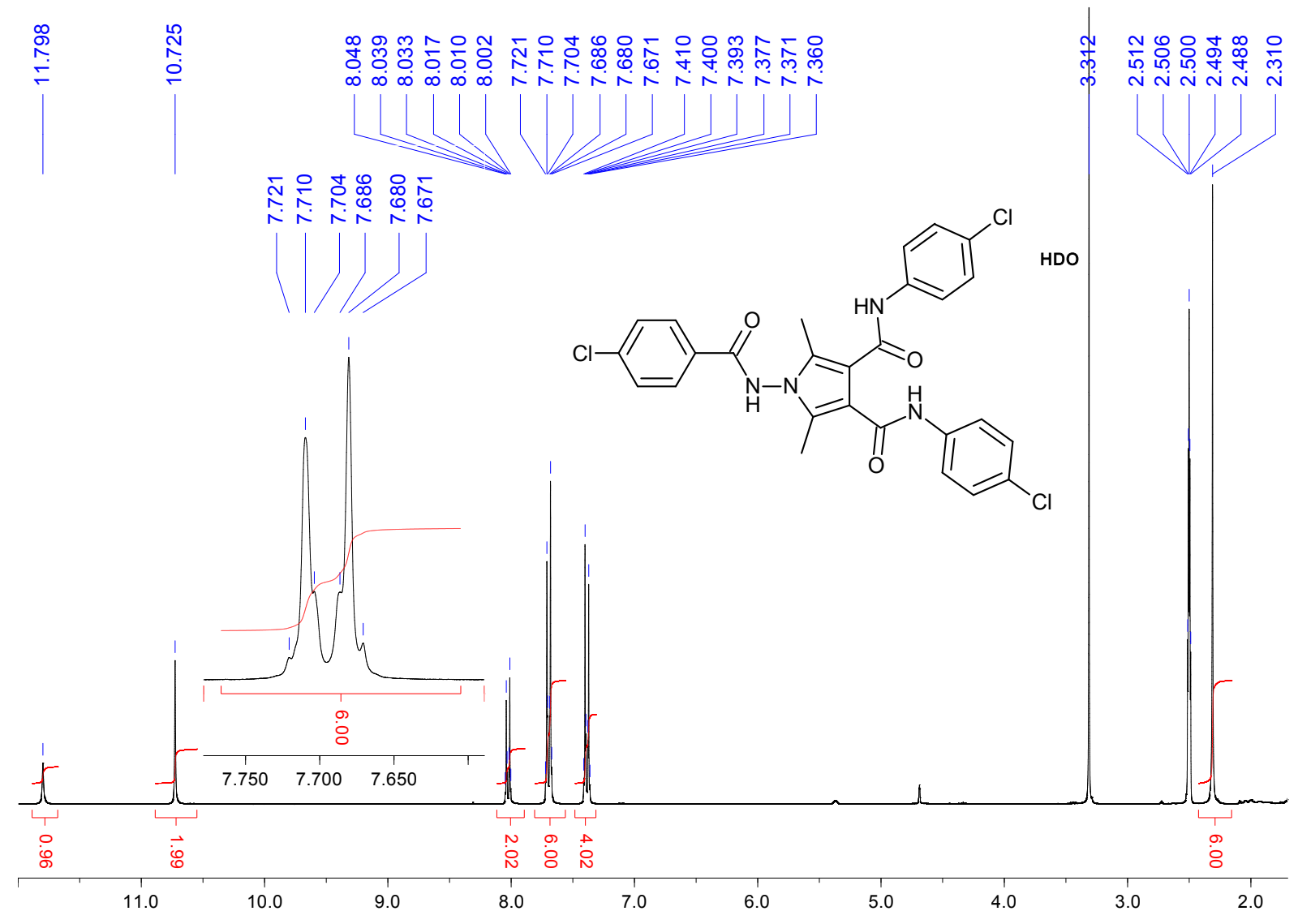

${ }^{1} \mathrm{H}$ NMR $\left(\mathrm{C}_{2} \mathrm{D}_{6} \mathrm{OS}, 300 \mathrm{MHz}\right)$ spectrum of 13 


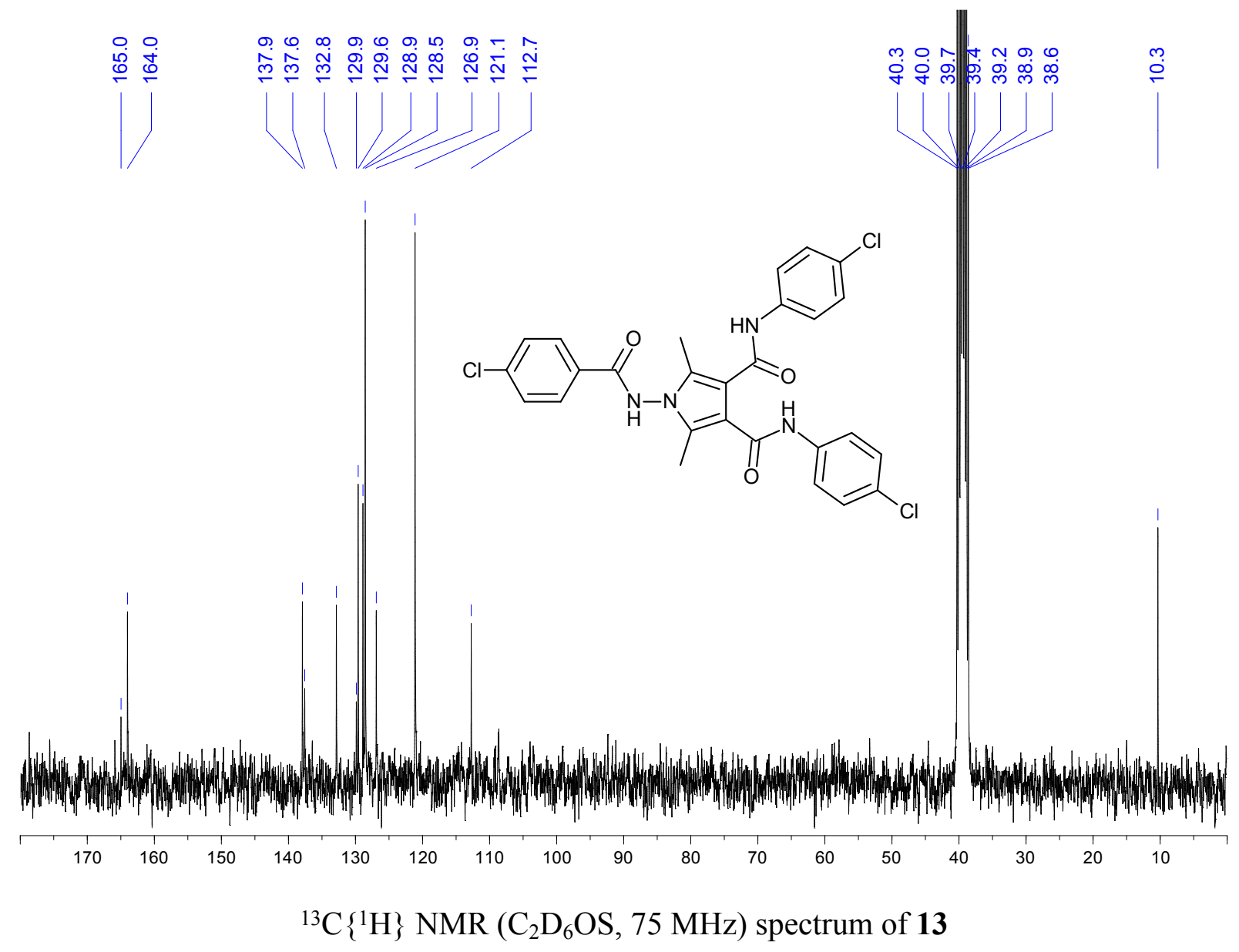



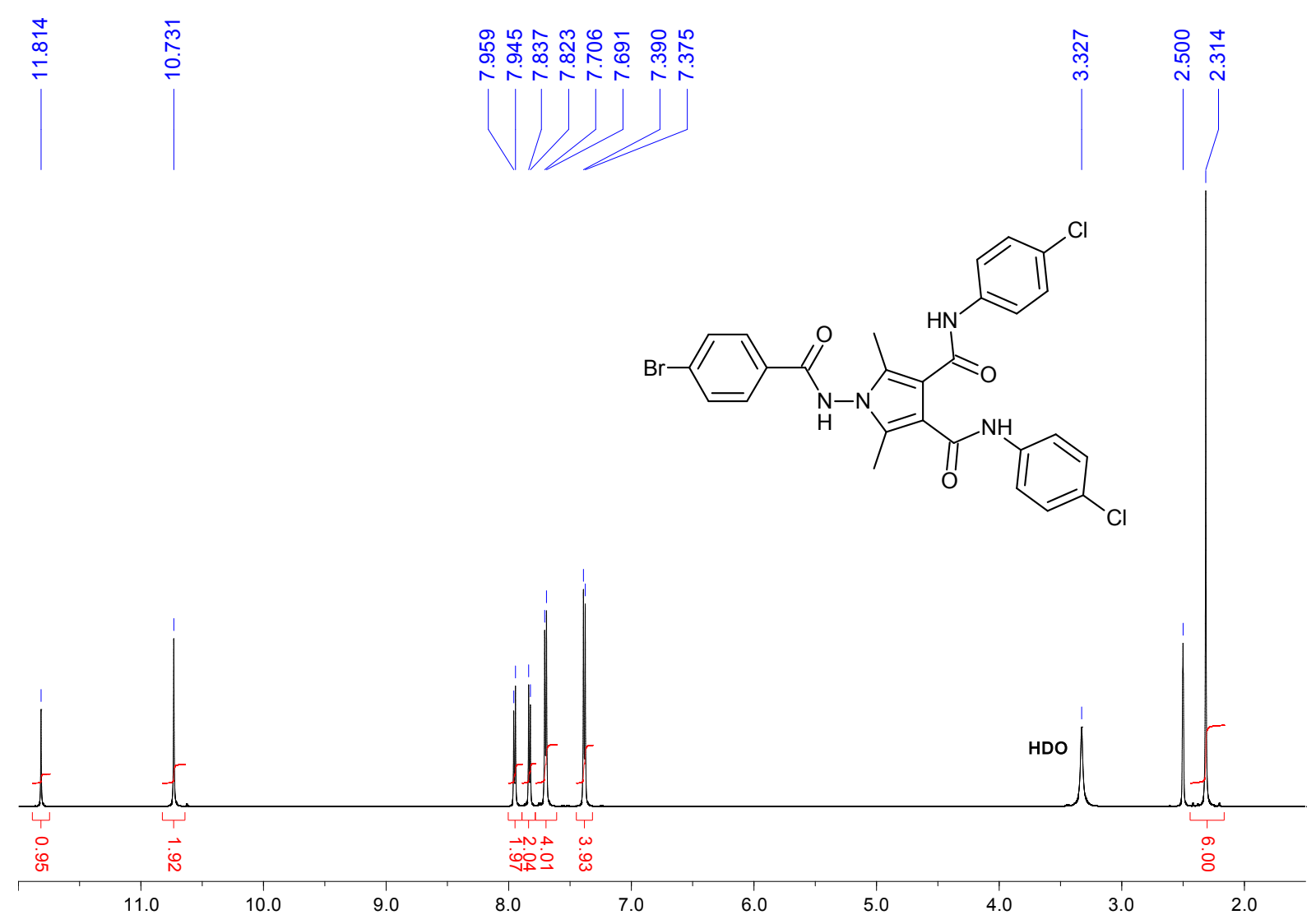

${ }^{1} \mathrm{H}$ NMR $\left(\mathrm{C}_{2} \mathrm{D}_{6} \mathrm{OS}, 600 \mathrm{MHz}\right)$ spectrum of $\mathbf{1 4}$ 


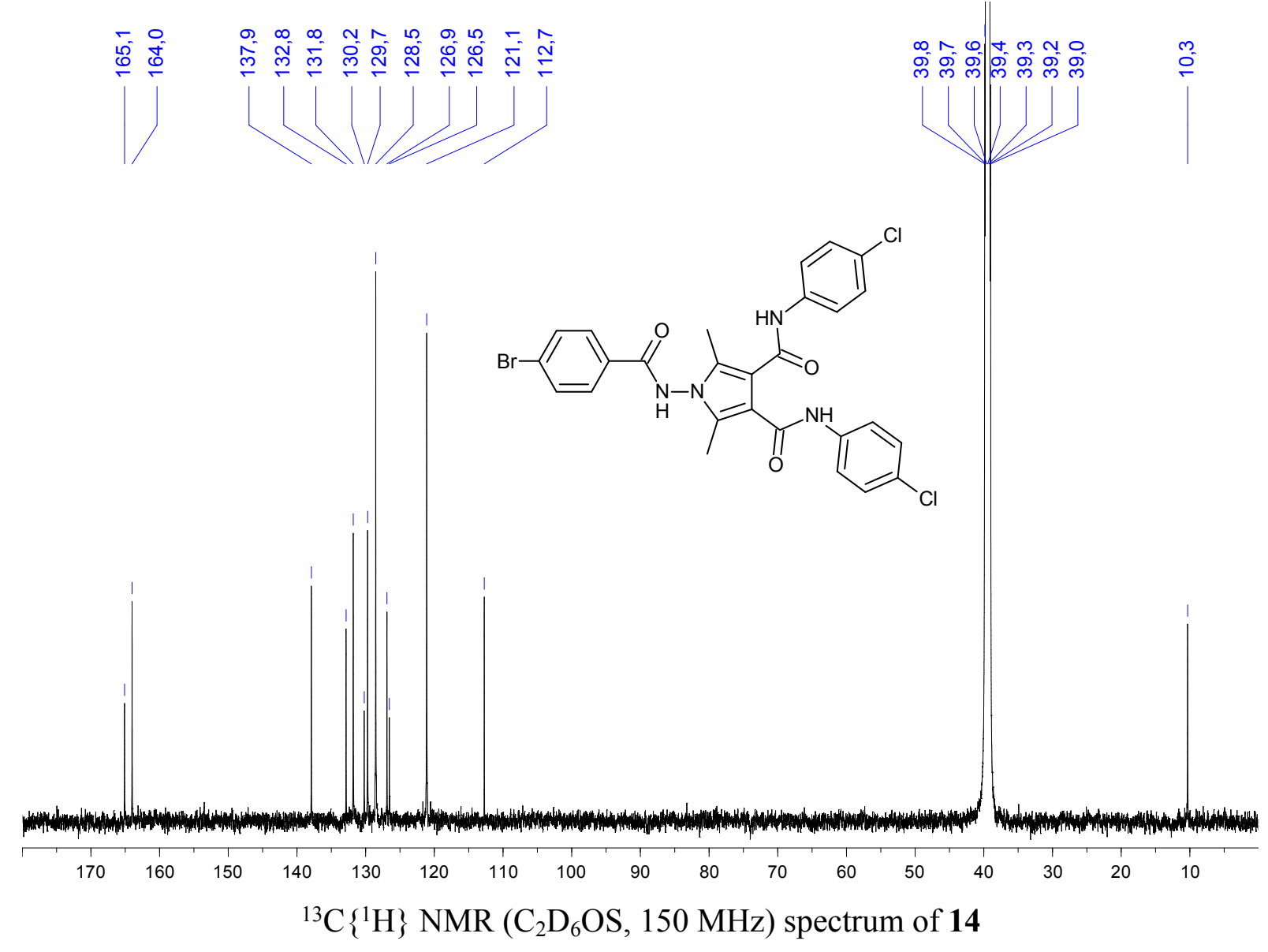




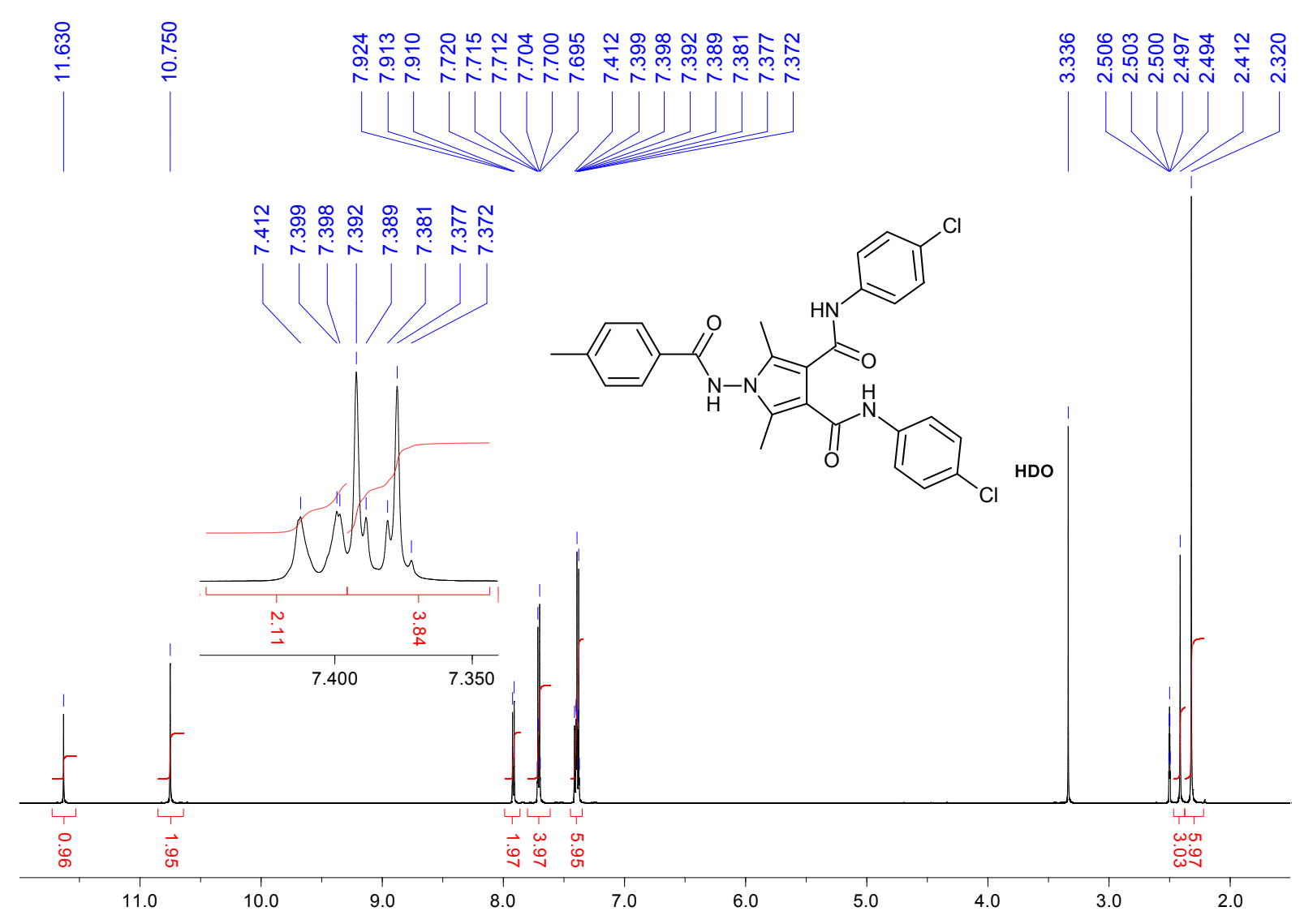

${ }^{1} \mathrm{H}$ NMR $\left(\mathrm{C}_{2} \mathrm{D}_{6} \mathrm{OS}, 600 \mathrm{MHz}\right)$ spectrum of $\mathbf{1 5}$ 


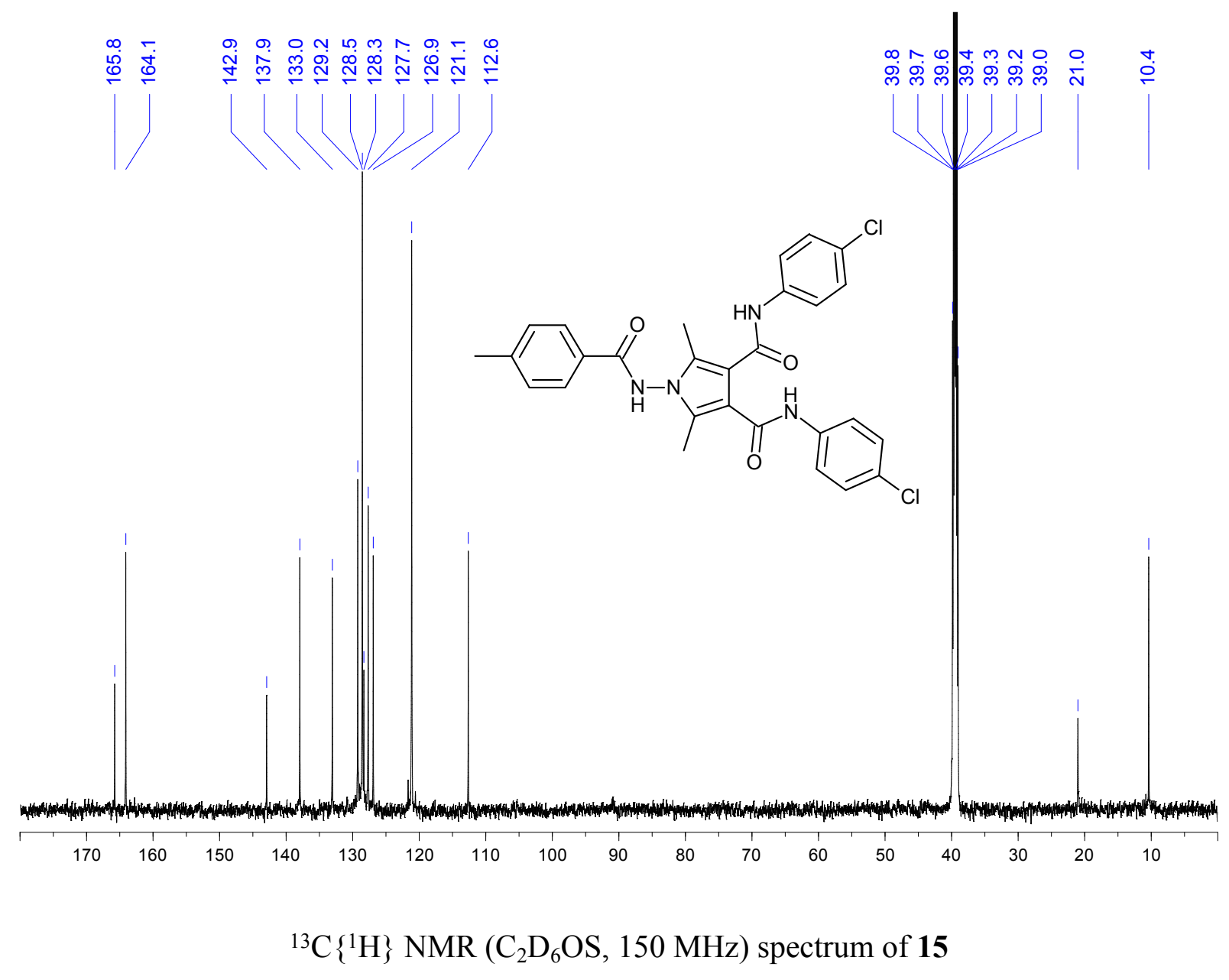




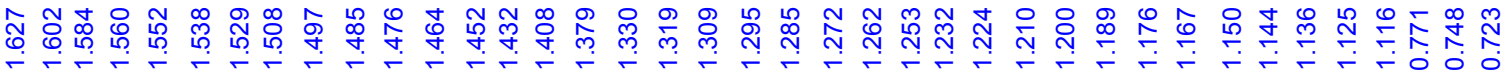

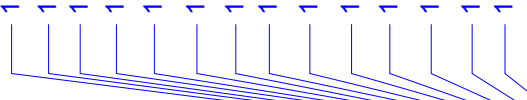

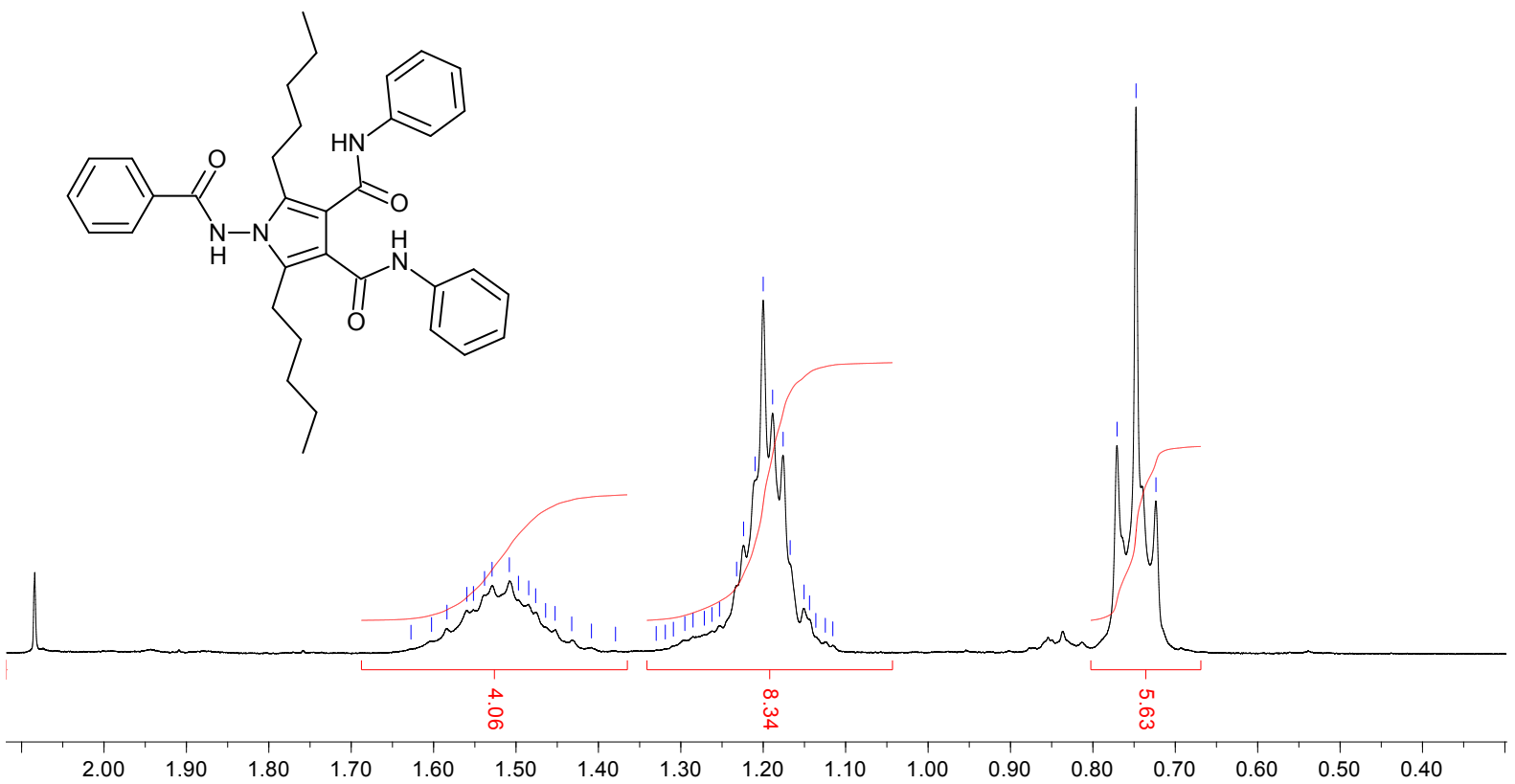

${ }^{1} \mathrm{H}$ NMR $\left(\mathrm{C}_{2} \mathrm{D}_{6} \mathrm{OS}, 300 \mathrm{MHz}\right)$ spectrum of $\mathbf{1 6}$ - part 1 of 3 (expanded) 


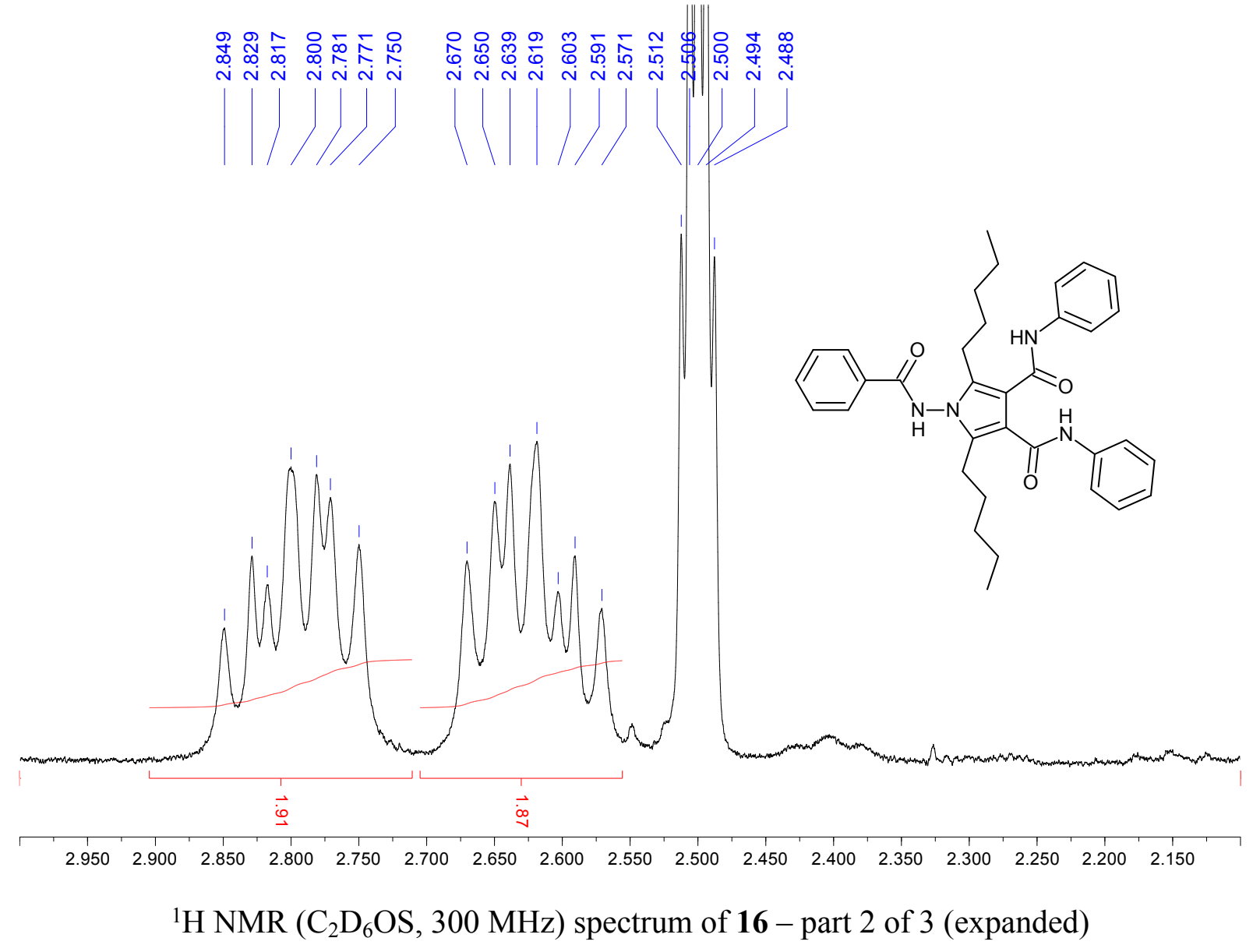




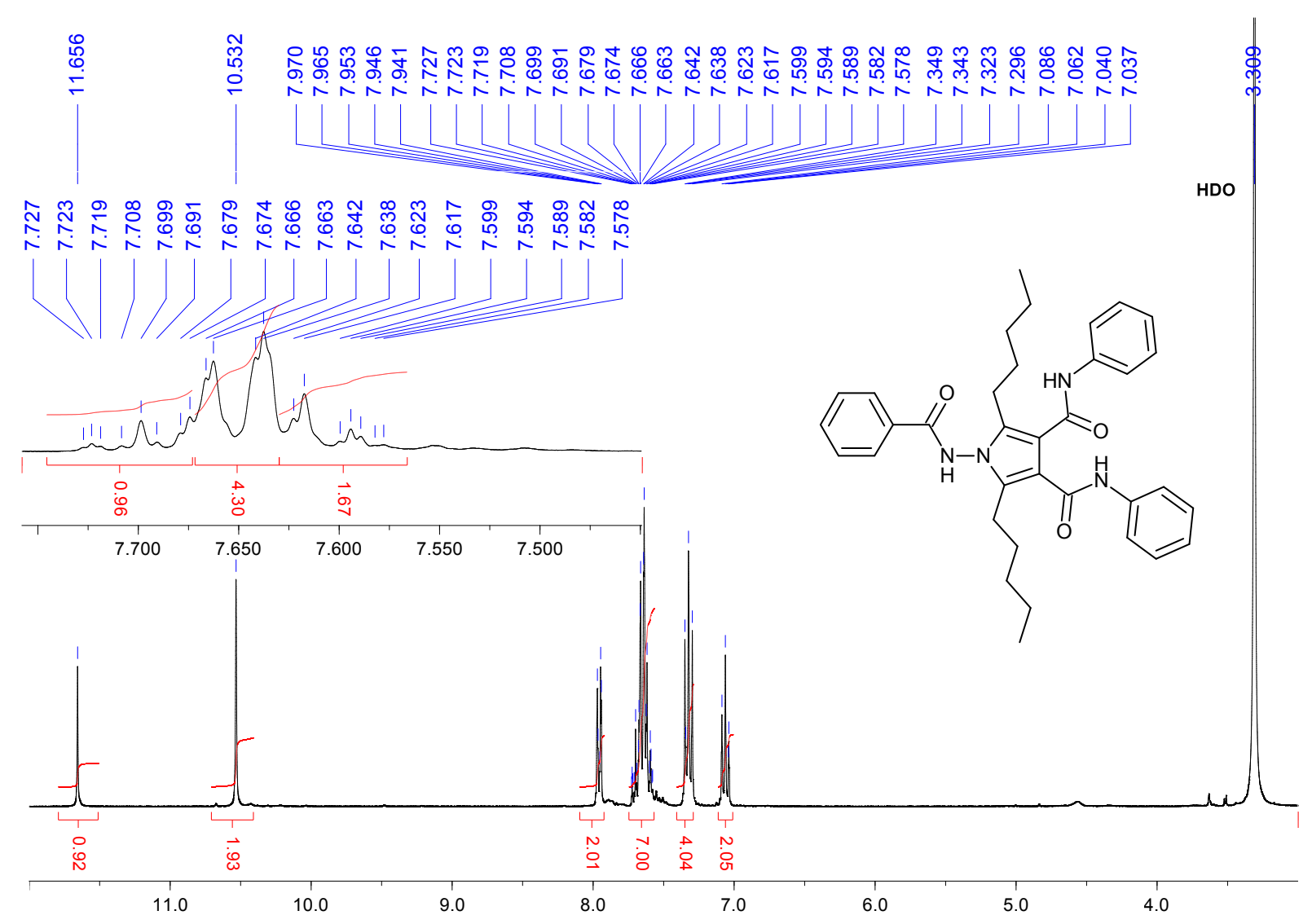

${ }^{1} \mathrm{H}$ NMR $\left(\mathrm{C}_{2} \mathrm{D}_{6} \mathrm{OS}, 300 \mathrm{MHz}\right)$ spectrum of $\mathbf{1 6}$ - part 3 of 3 (expanded) 


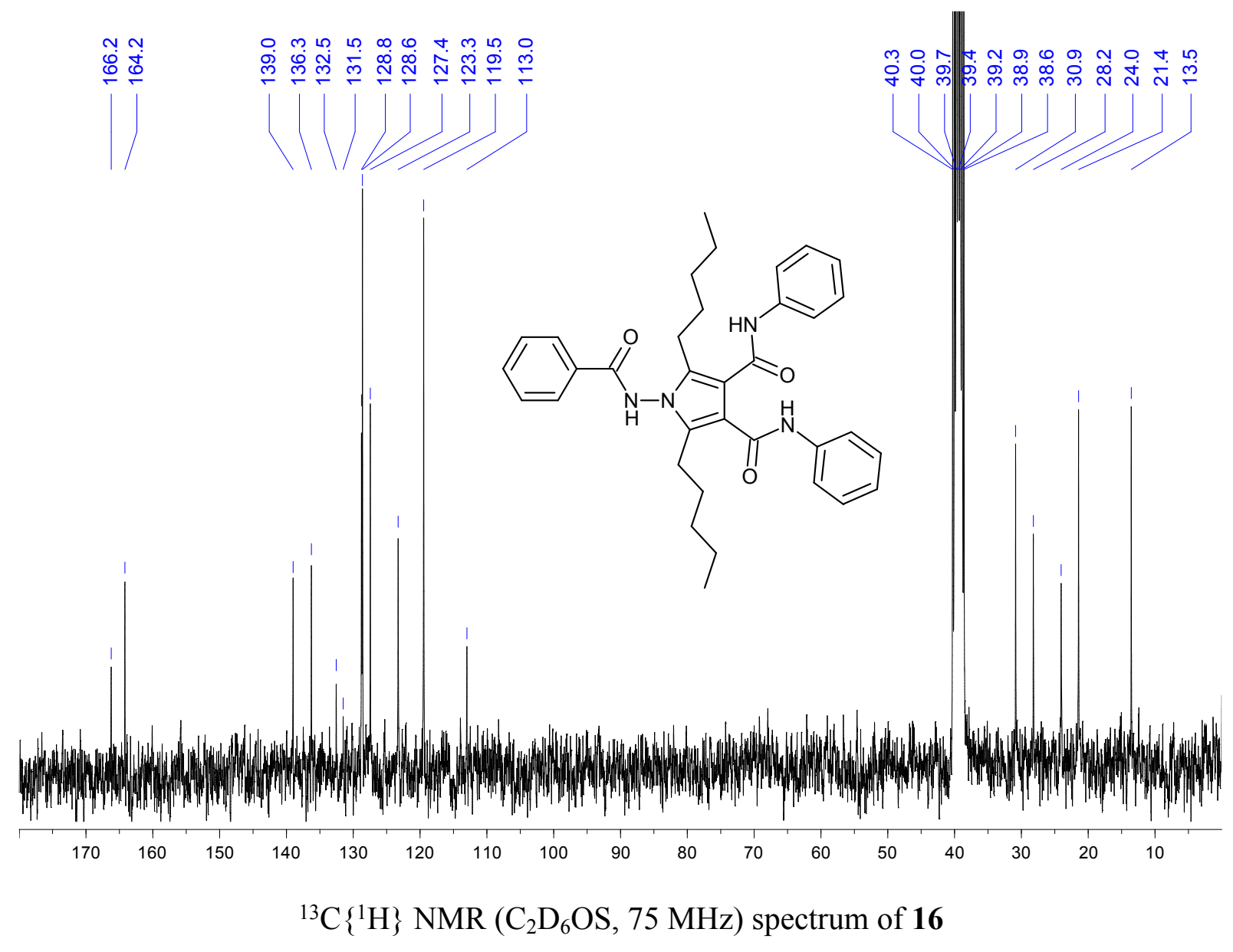




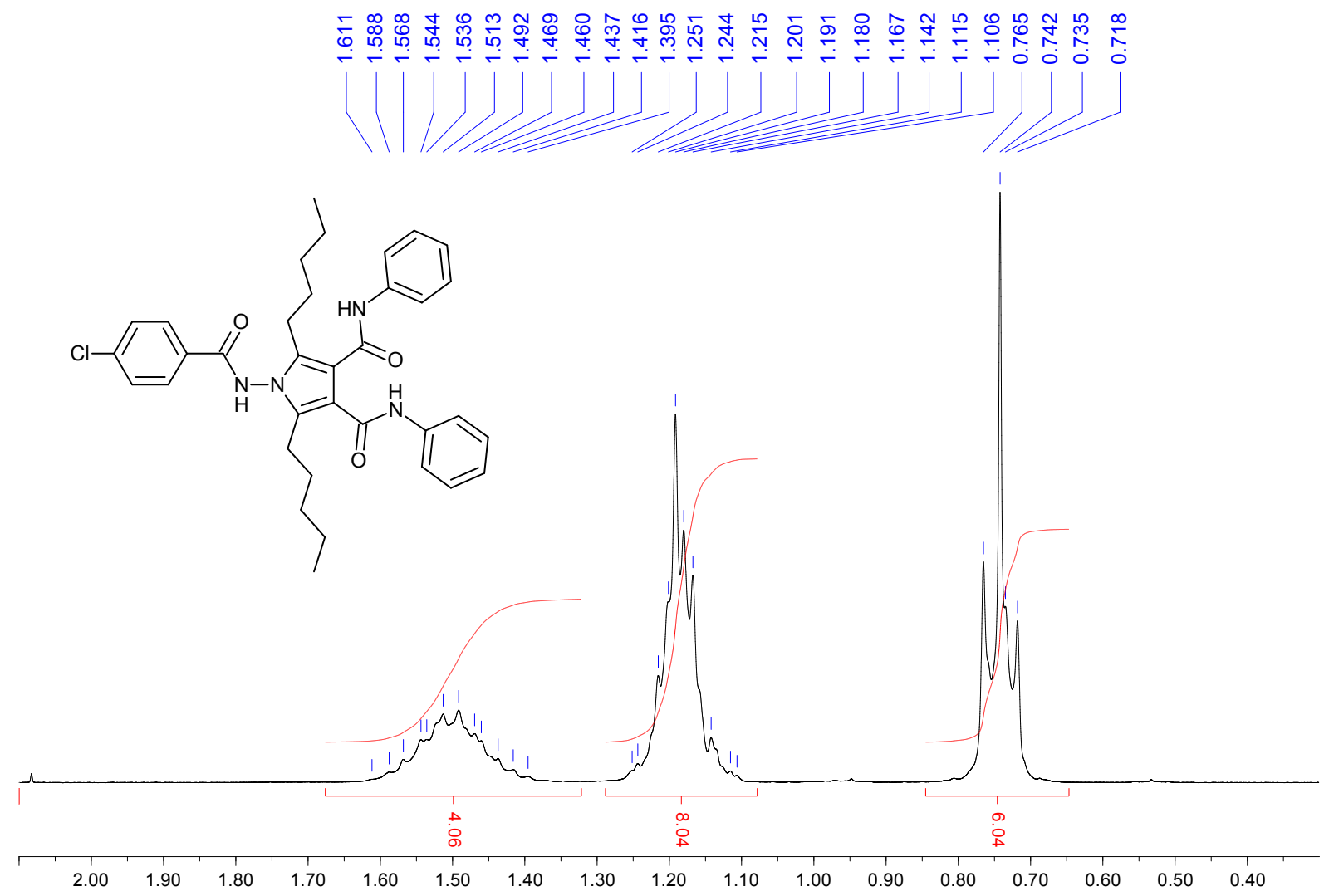

${ }^{1} \mathrm{H}$ NMR $\left(\mathrm{C}_{2} \mathrm{D}_{6} \mathrm{OS}, 300 \mathrm{MHz}\right)$ spectrum of 17 - part 1 of 3 (expanded) 


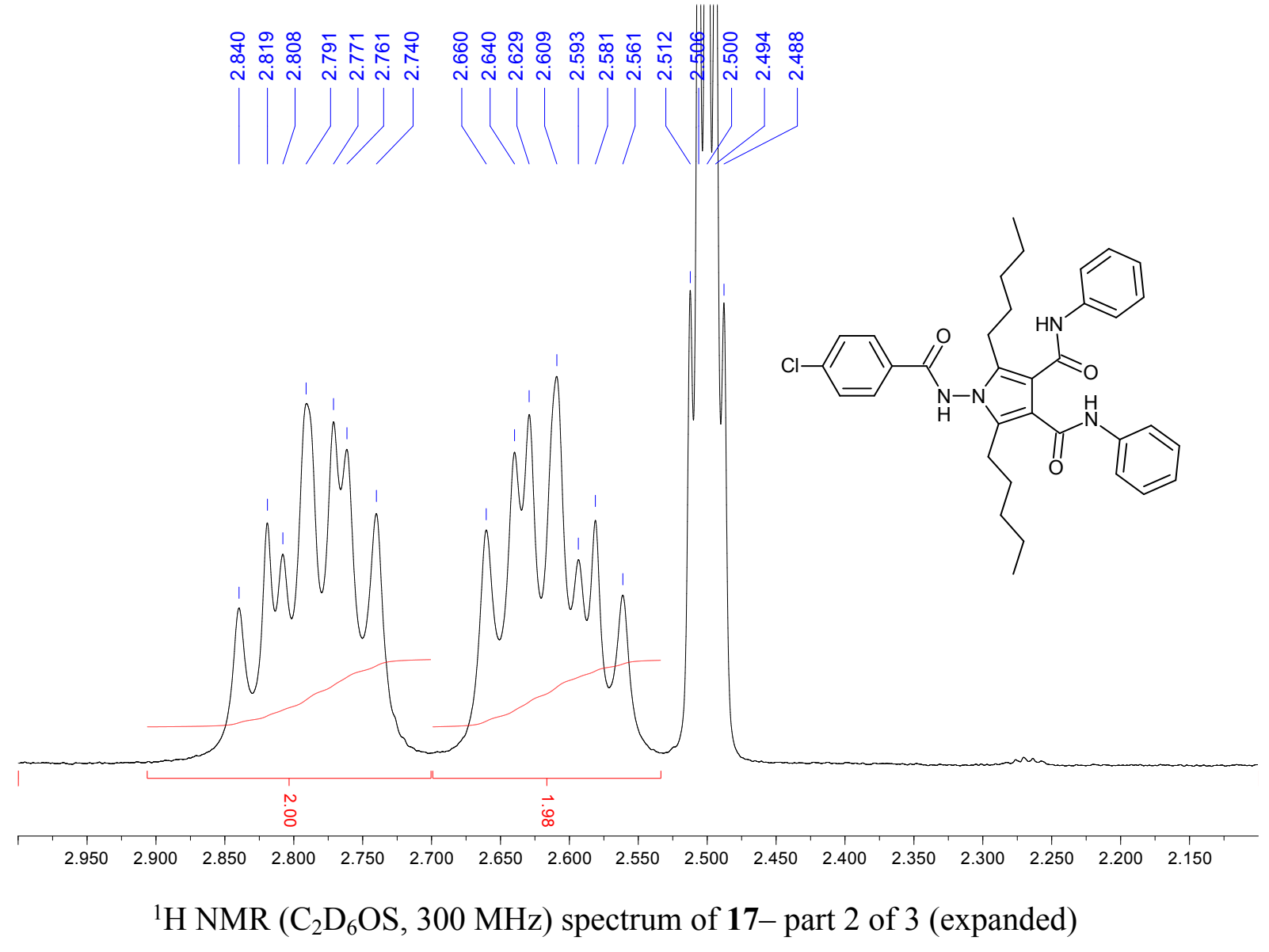



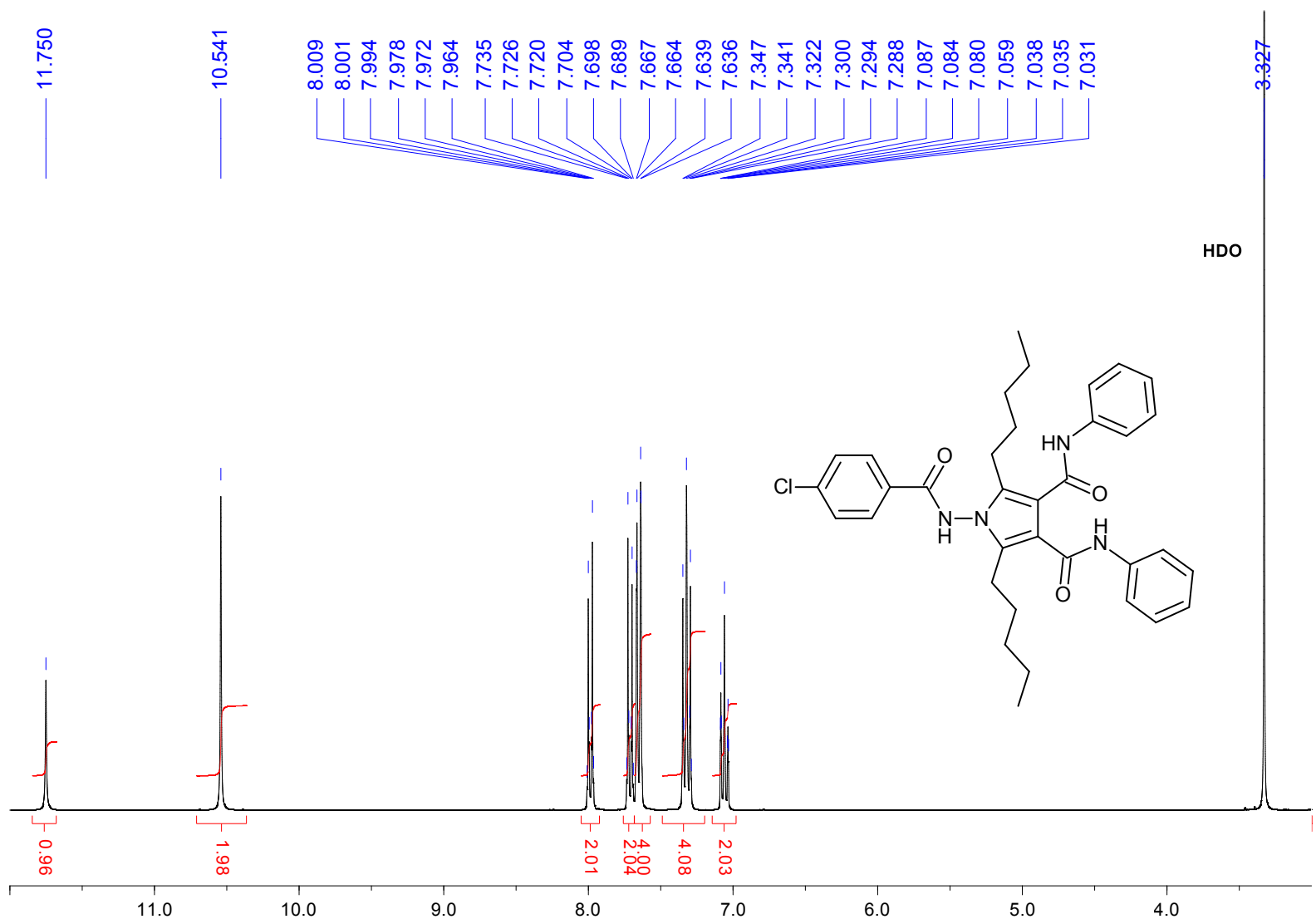

${ }^{1} \mathrm{H}$ NMR $\left(\mathrm{C}_{2} \mathrm{D}_{6} \mathrm{OS}, 300 \mathrm{MHz}\right)$ spectrum of 17 - part 3 of 3 (expanded) 


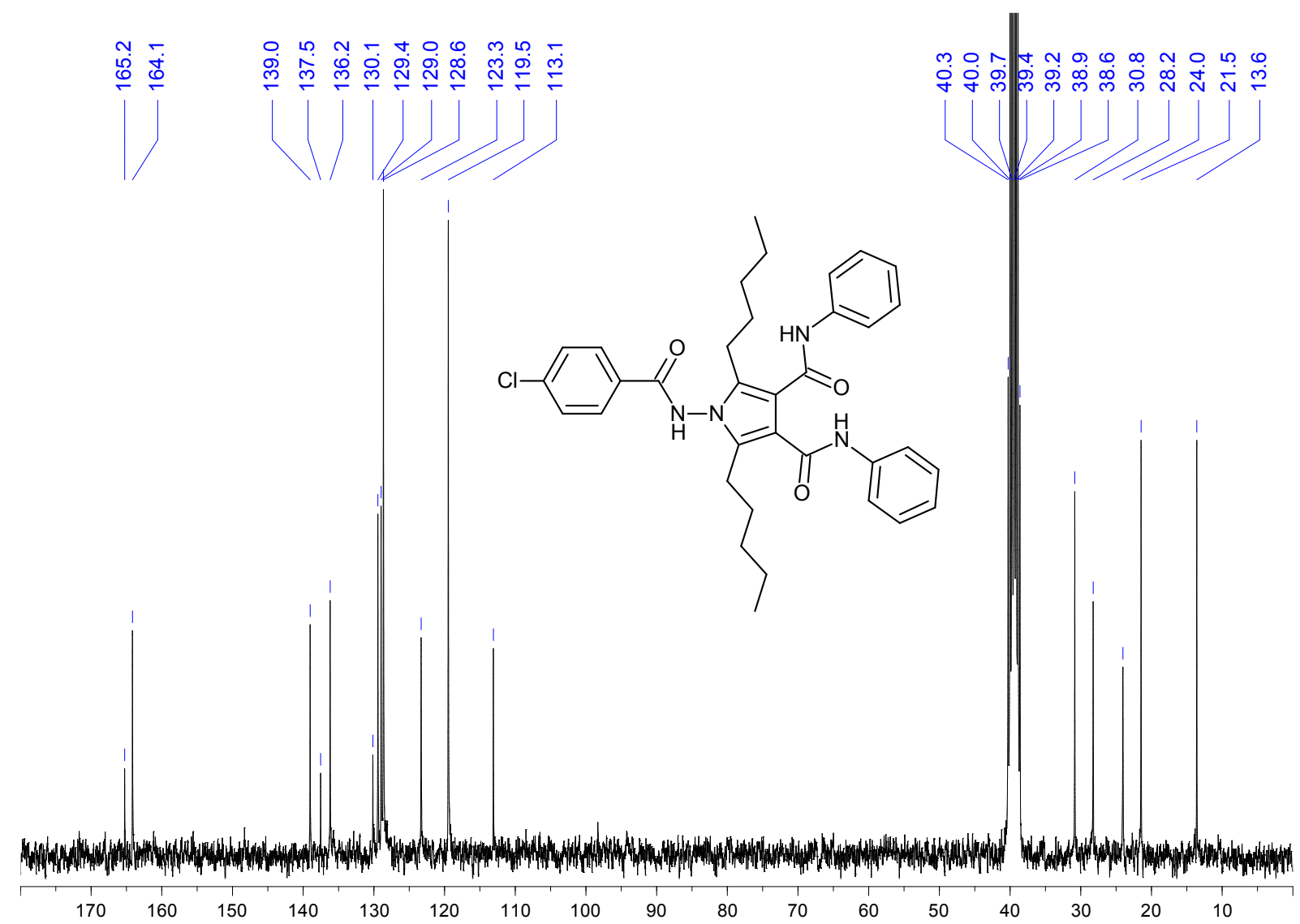

${ }^{13} \mathrm{C}\left\{{ }^{1} \mathrm{H}\right\}$ NMR $\left(\mathrm{C}_{2} \mathrm{D}_{6} \mathrm{OS}, 75 \mathrm{MHz}\right)$ spectrum of $\mathbf{1 7}$ 


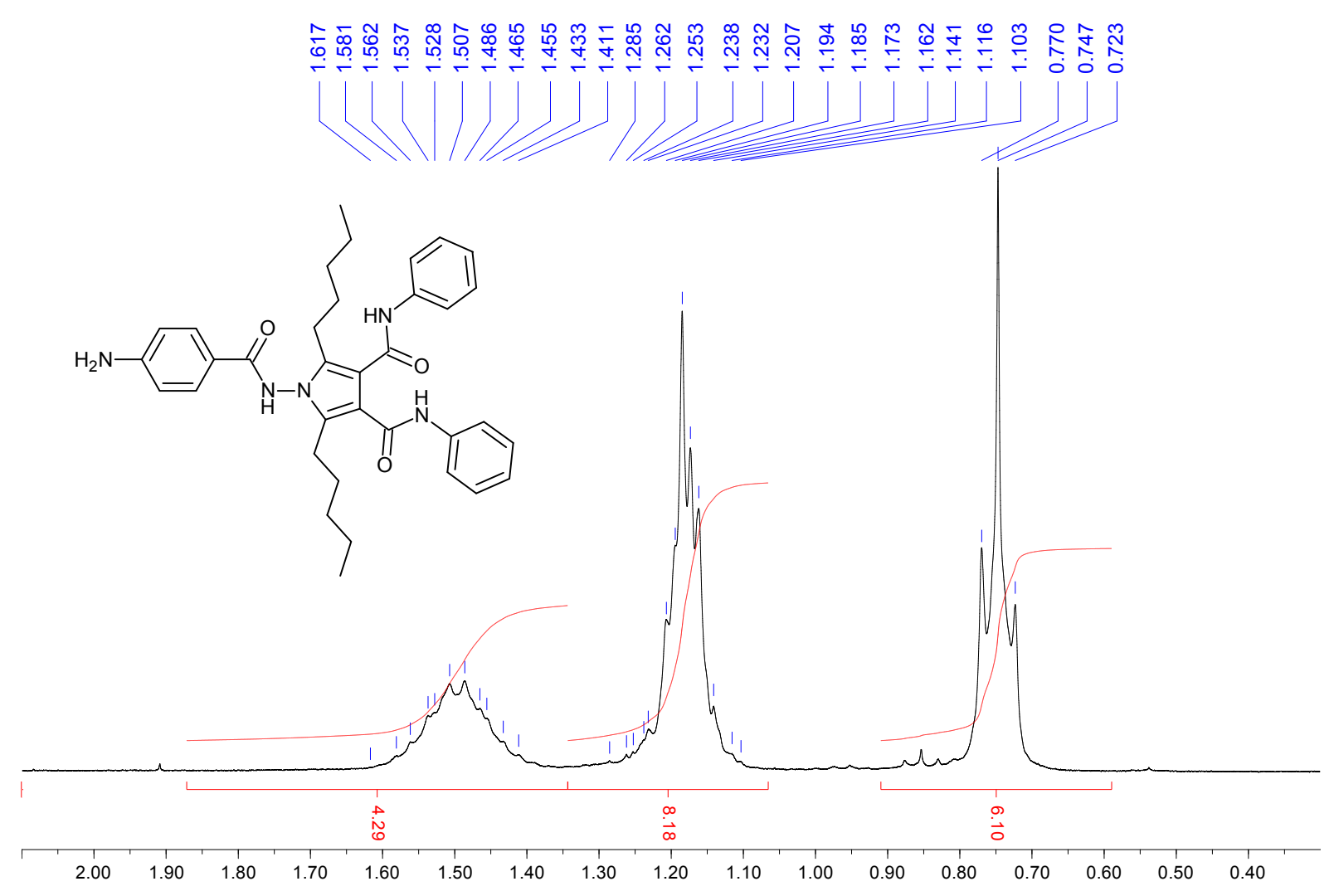

${ }^{1} \mathrm{H}$ NMR $\left(\mathrm{C}_{2} \mathrm{D}_{6} \mathrm{OS}, 300 \mathrm{MHz}\right)$ spectrum of 18 - part 1 of 3 (expanded) 


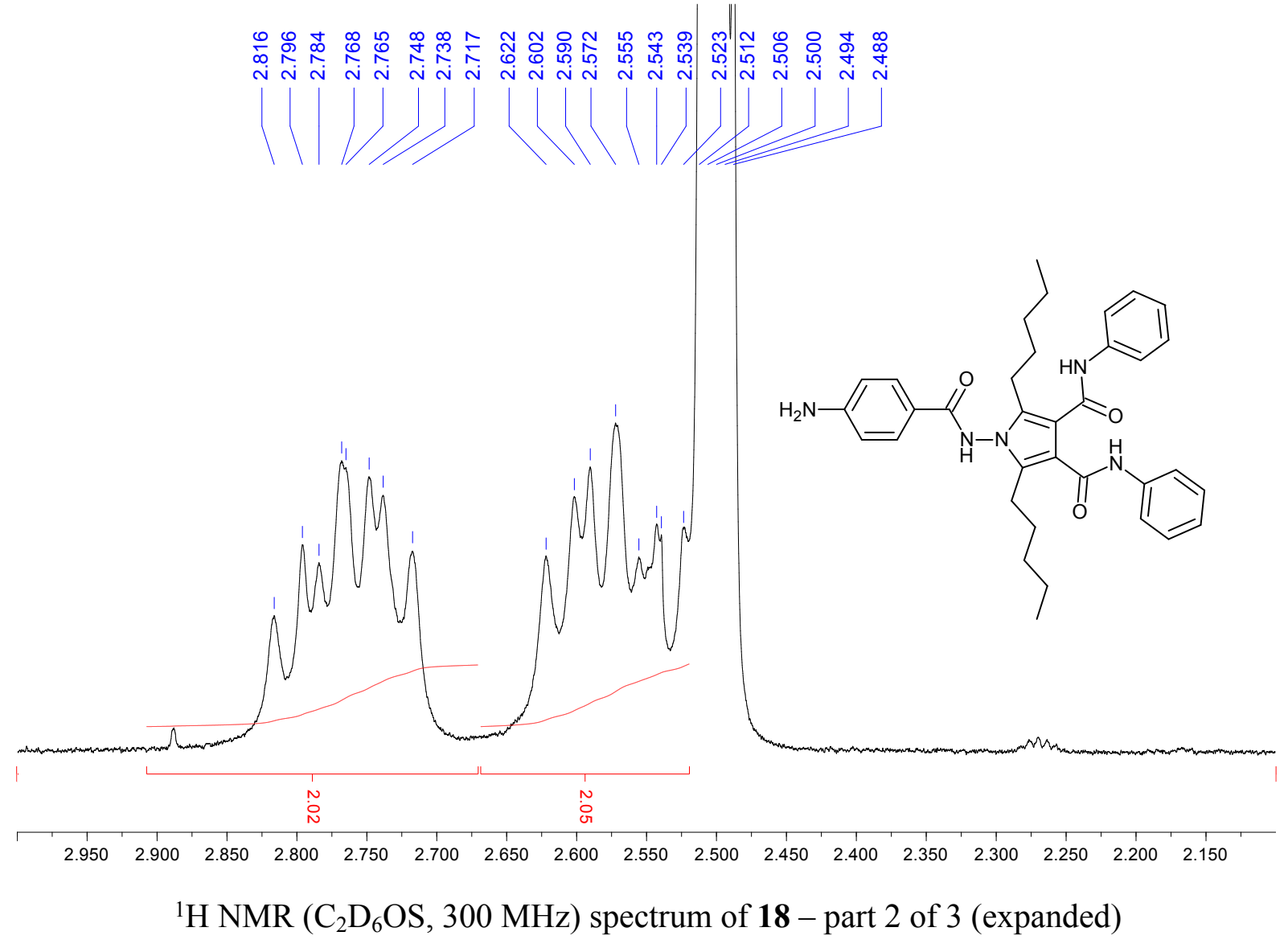




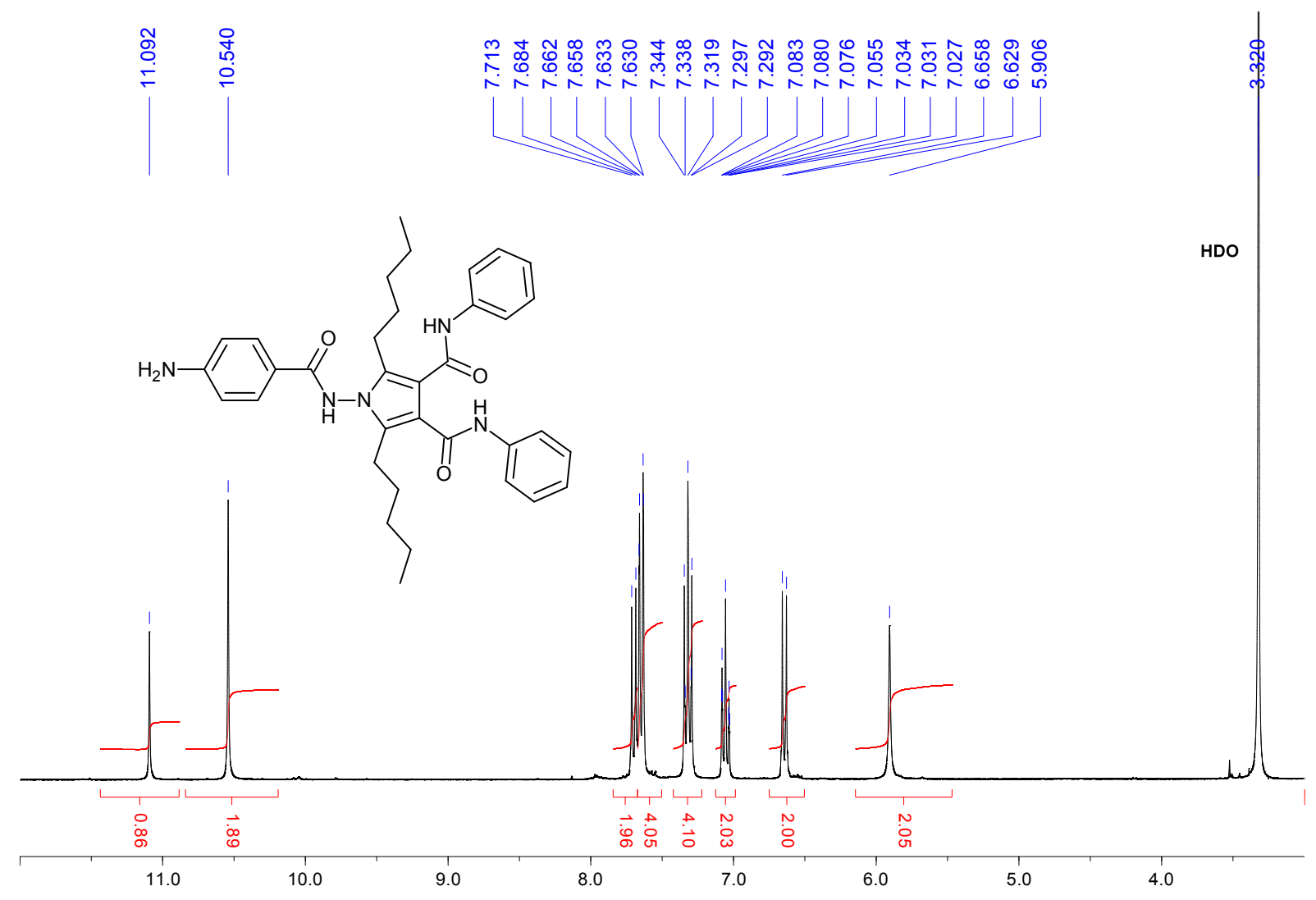

${ }^{1} \mathrm{H}$ NMR $\left(\mathrm{C}_{2} \mathrm{D}_{6} \mathrm{OS}, 300 \mathrm{MHz}\right)$ spectrum of 18 - part 3 of 3 (expanded) 


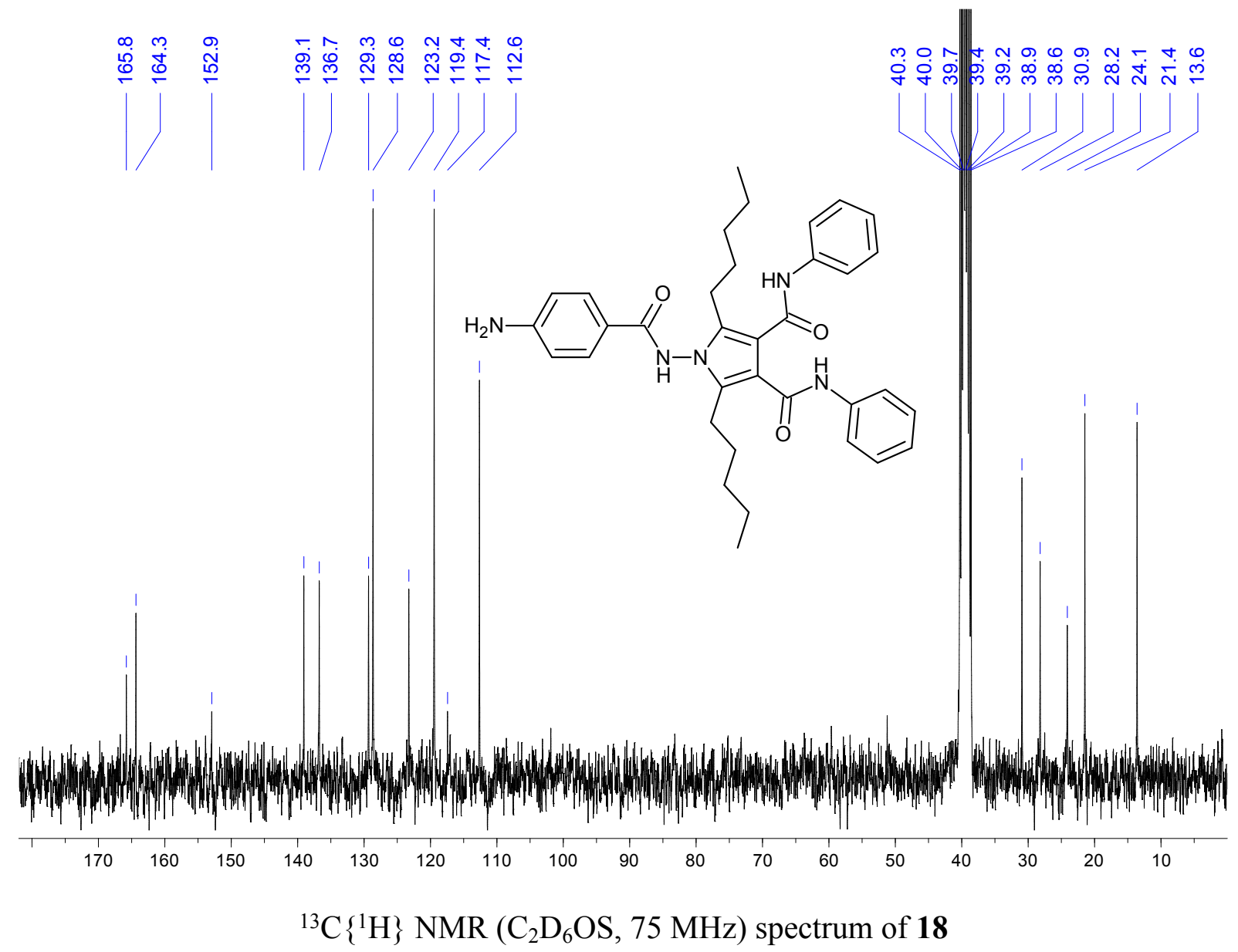




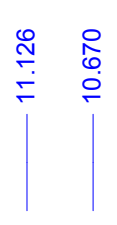

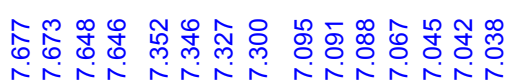

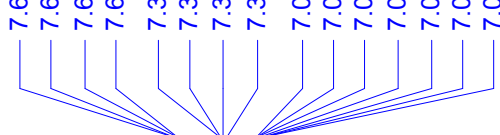

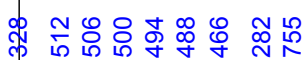

管

in

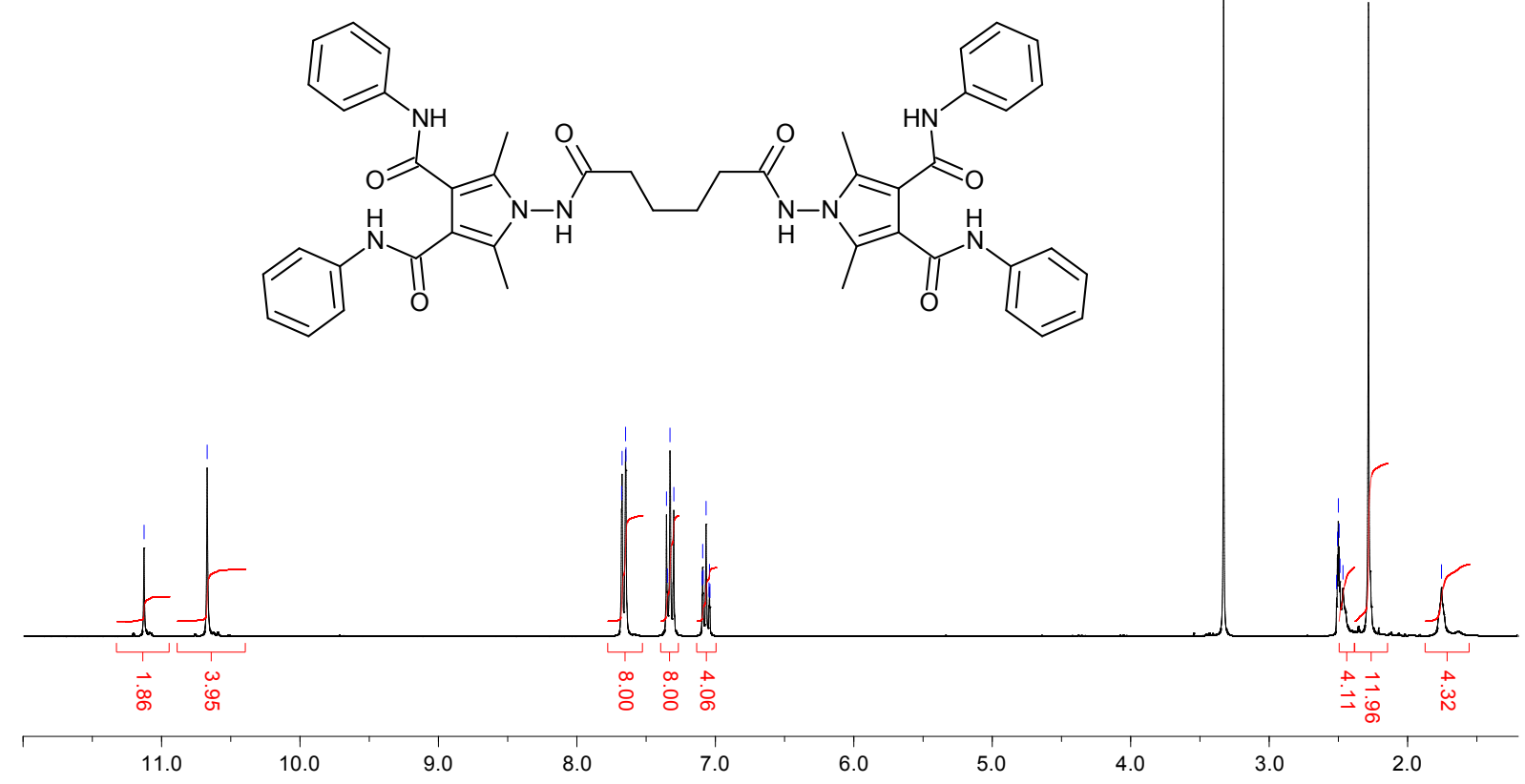

HDO

${ }^{1} \mathrm{H}$ NMR $\left(\mathrm{C}_{2} \mathrm{D}_{6} \mathrm{OS}, 300 \mathrm{MHz}\right)$ spectrum of $\mathbf{1 9}$ 


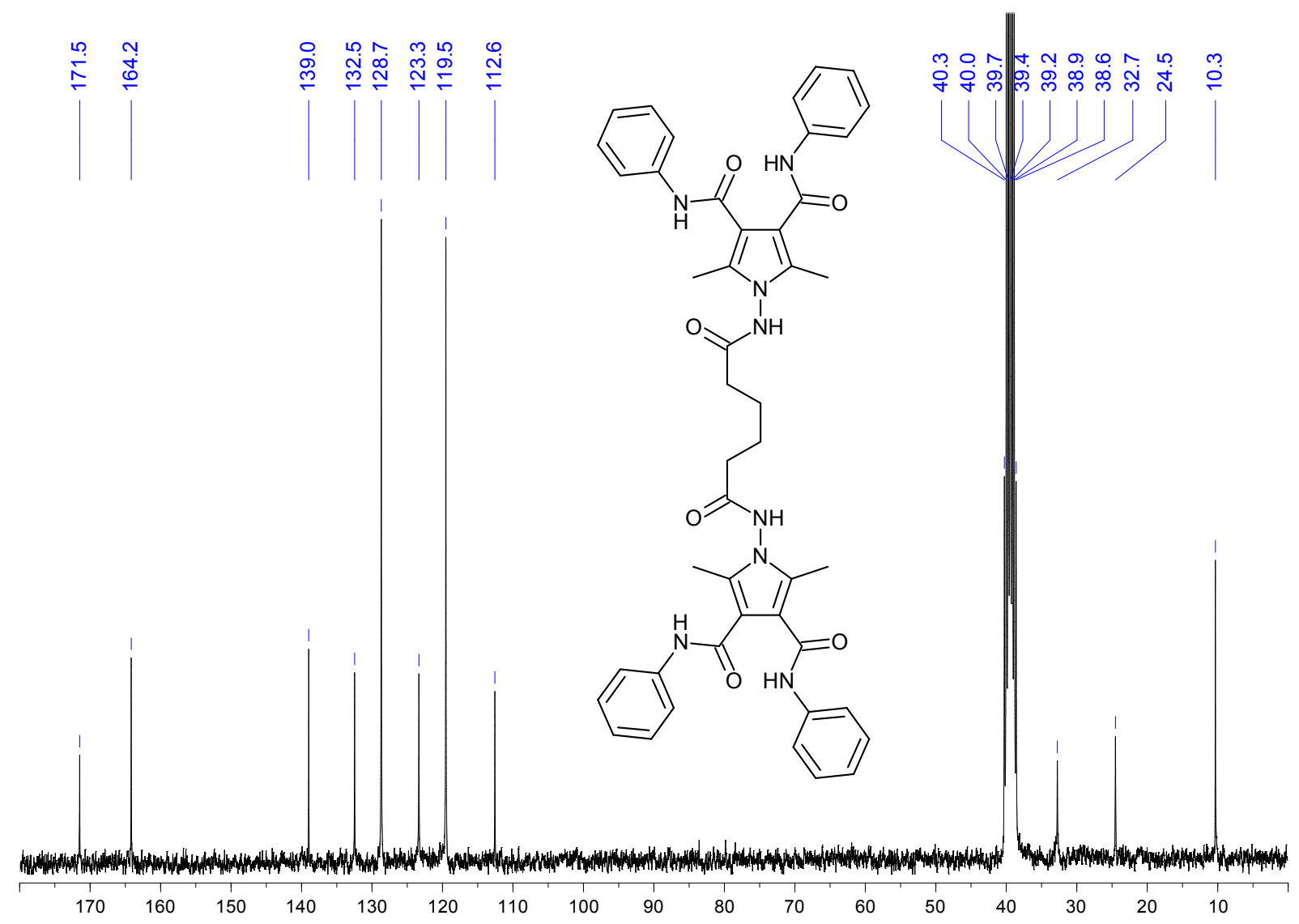

${ }^{13} \mathrm{C}\left\{{ }^{1} \mathrm{H}\right\}$ NMR $\left(\mathrm{C}_{2} \mathrm{D}_{6} \mathrm{OS}, 75 \mathrm{MHz}\right)$ spectrum of $\mathbf{1 9}$ 


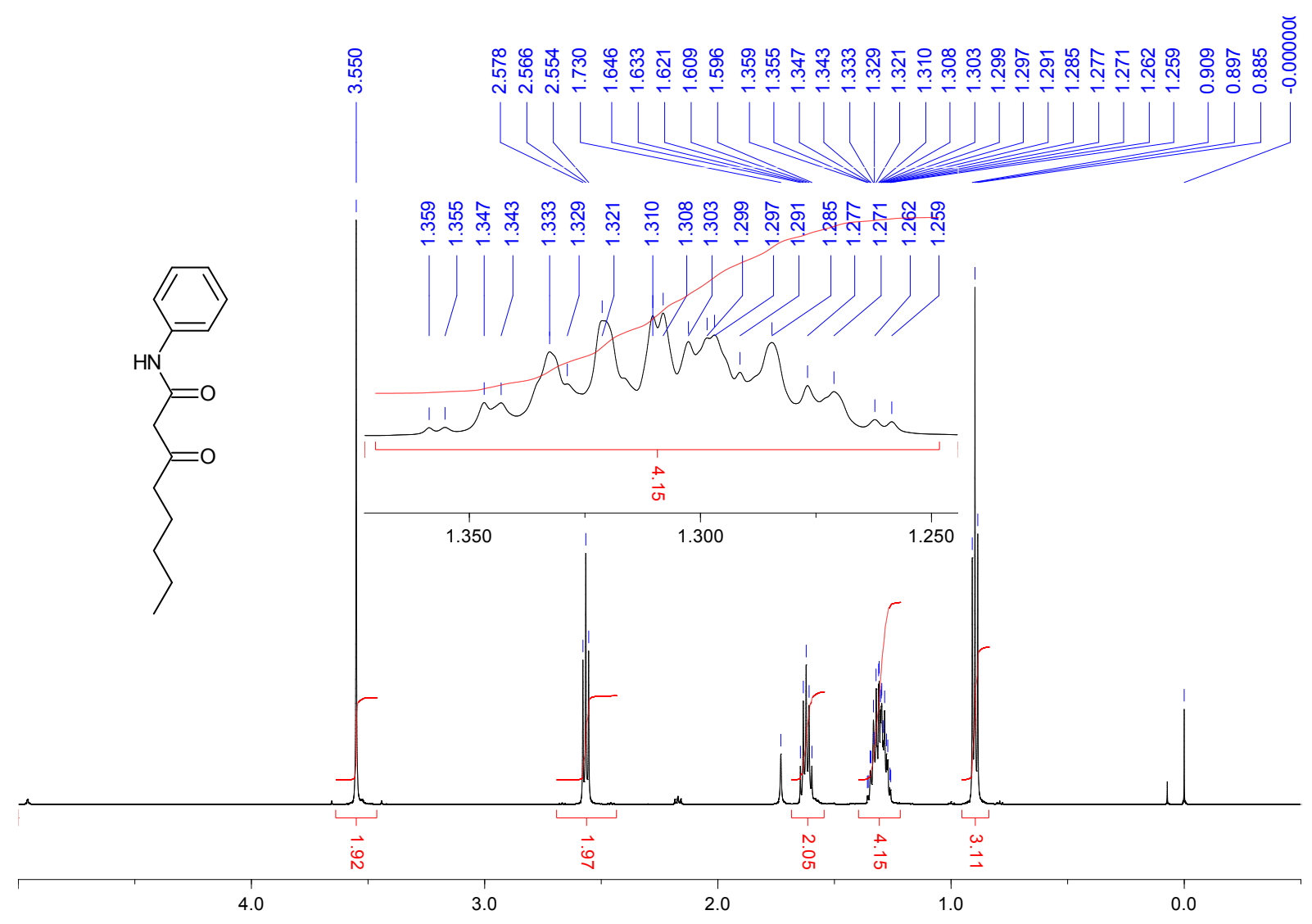

${ }^{1} \mathrm{H}$ NMR $\left(\mathrm{C}_{2} \mathrm{D}_{6} \mathrm{OS}, 300 \mathrm{MHz}\right)$ spectrum of $\mathbf{A 3}$ - part 1 of 2 (expanded) 


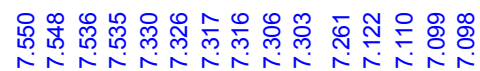
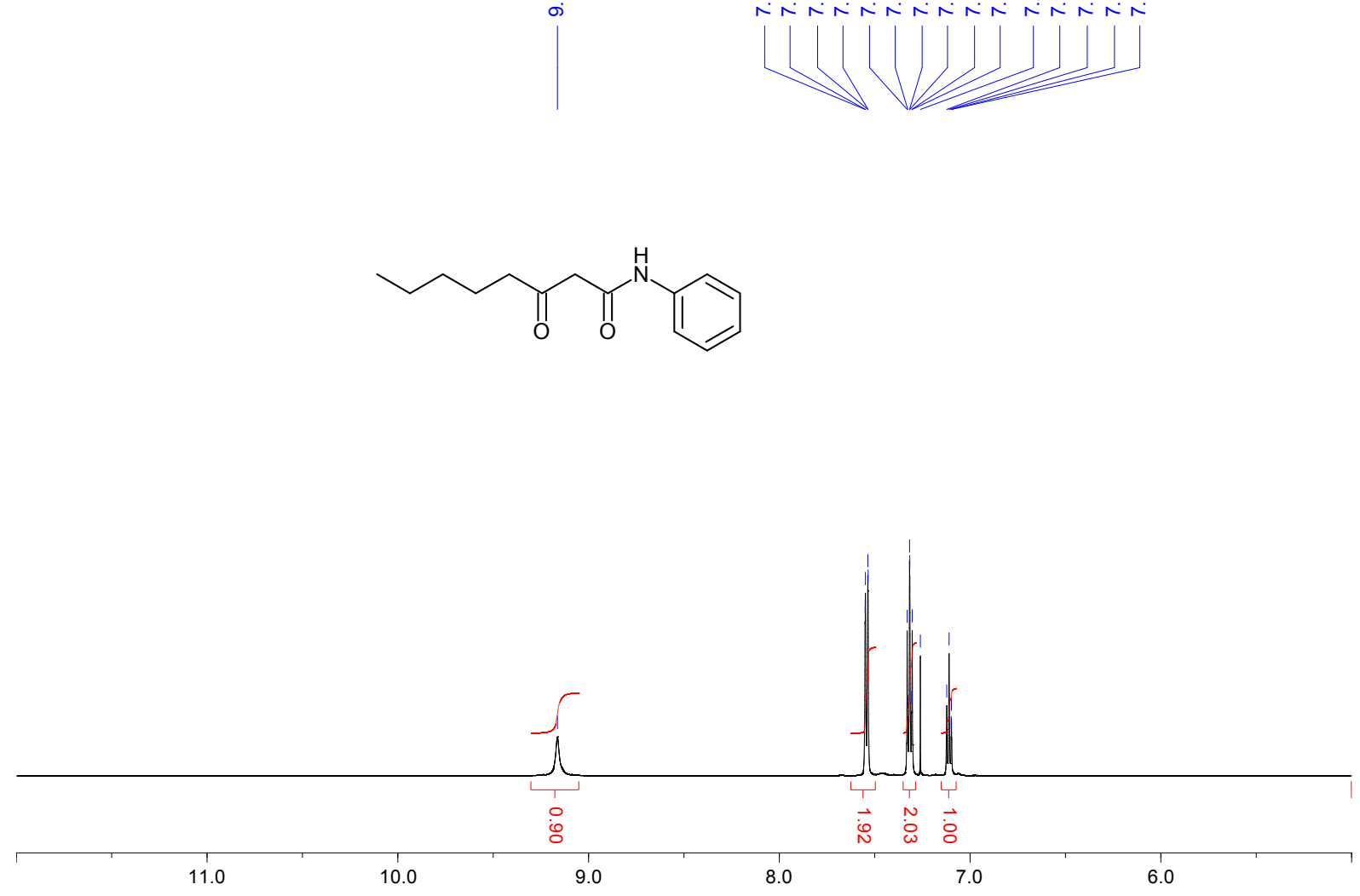

${ }^{1} \mathrm{H}$ NMR $\left(\mathrm{C}_{2} \mathrm{D}_{6} \mathrm{OS}, 300 \mathrm{MHz}\right)$ spectrum of $\mathbf{A 3}$ - part 2 of 2 (expanded) 


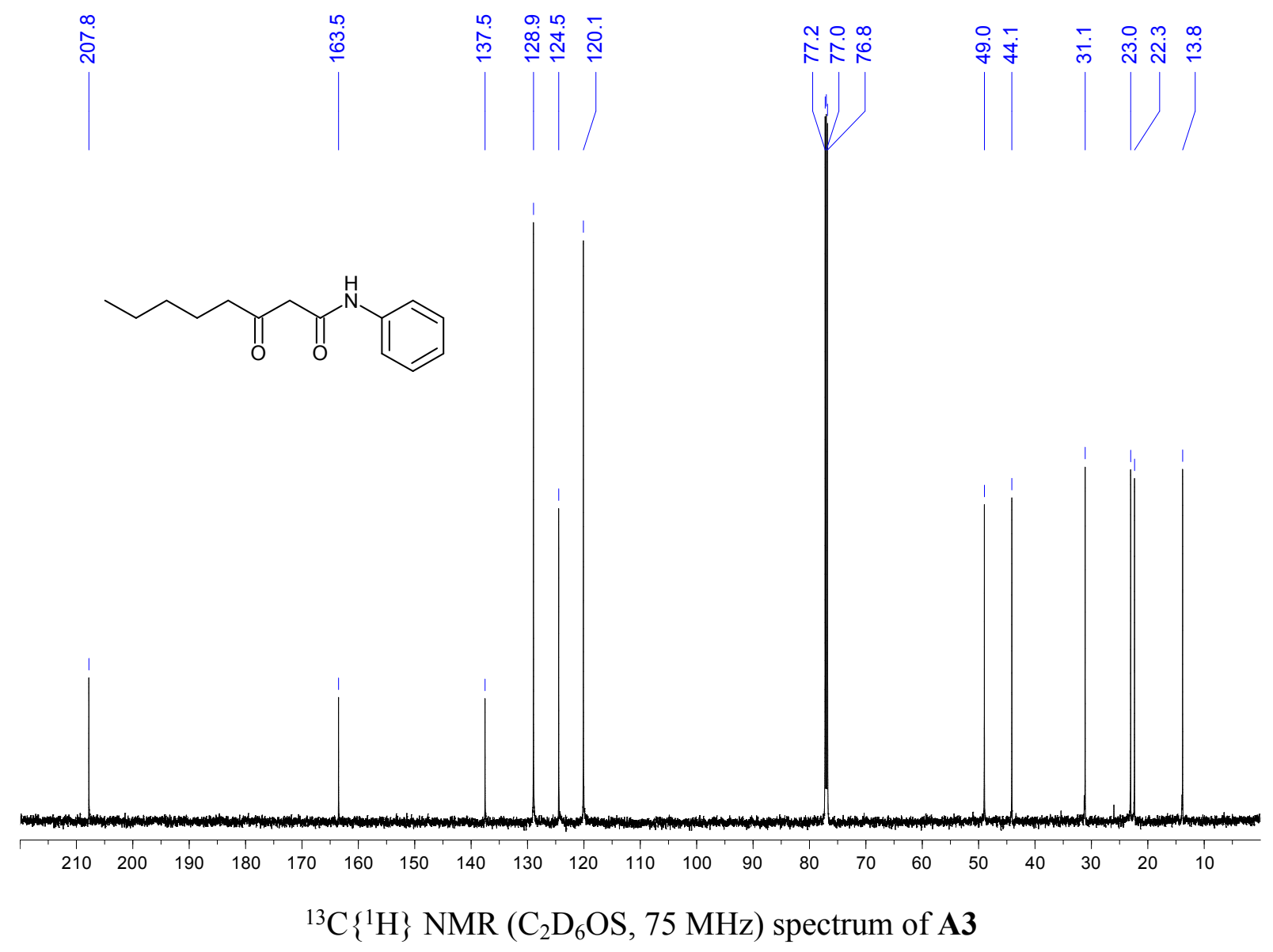




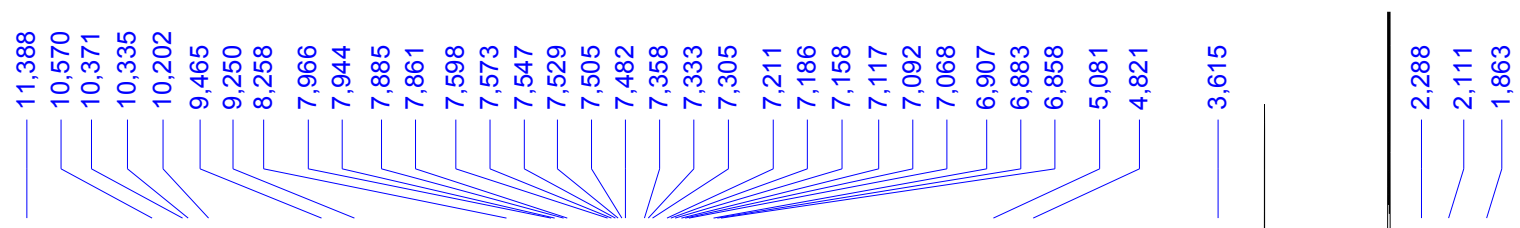

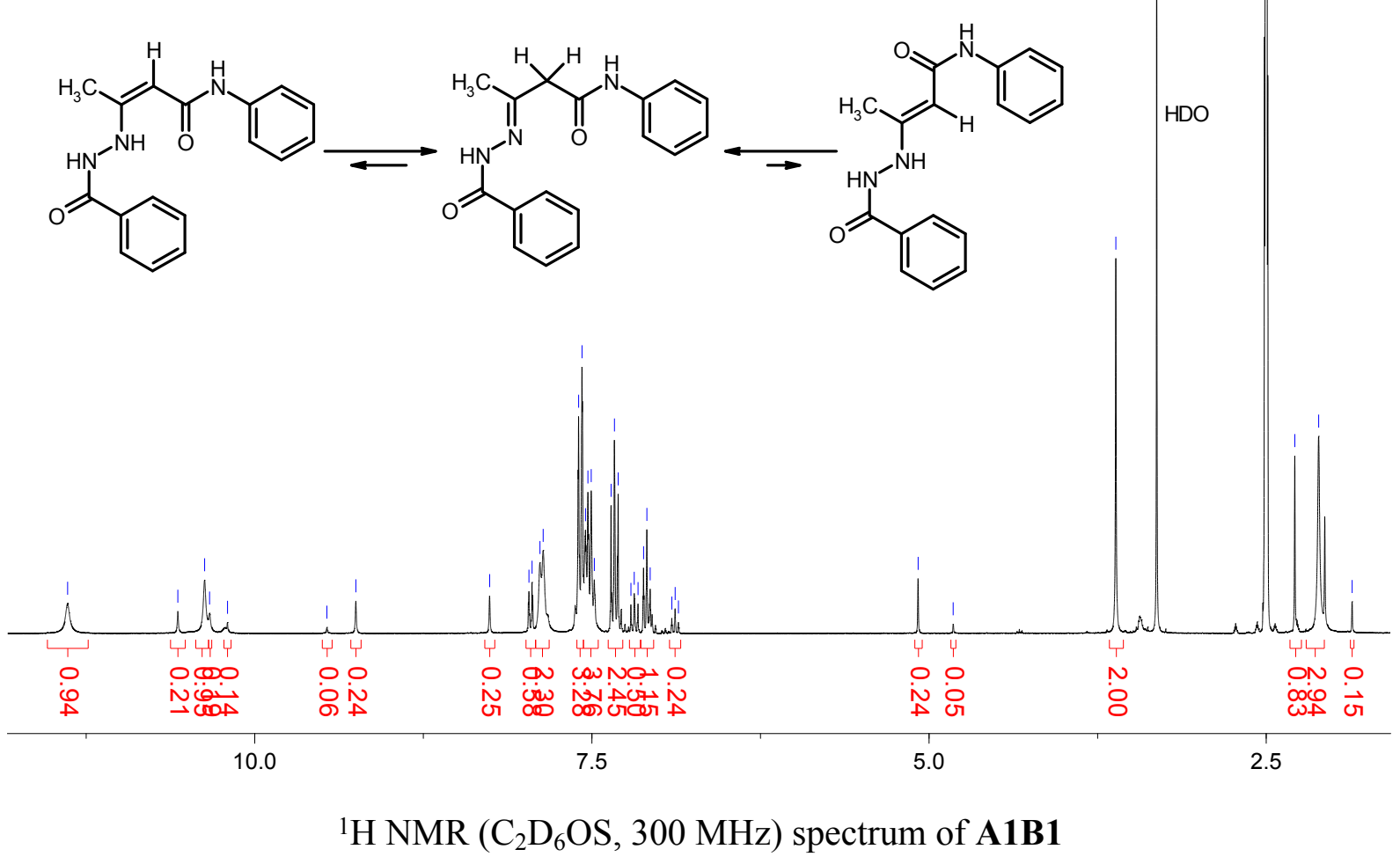



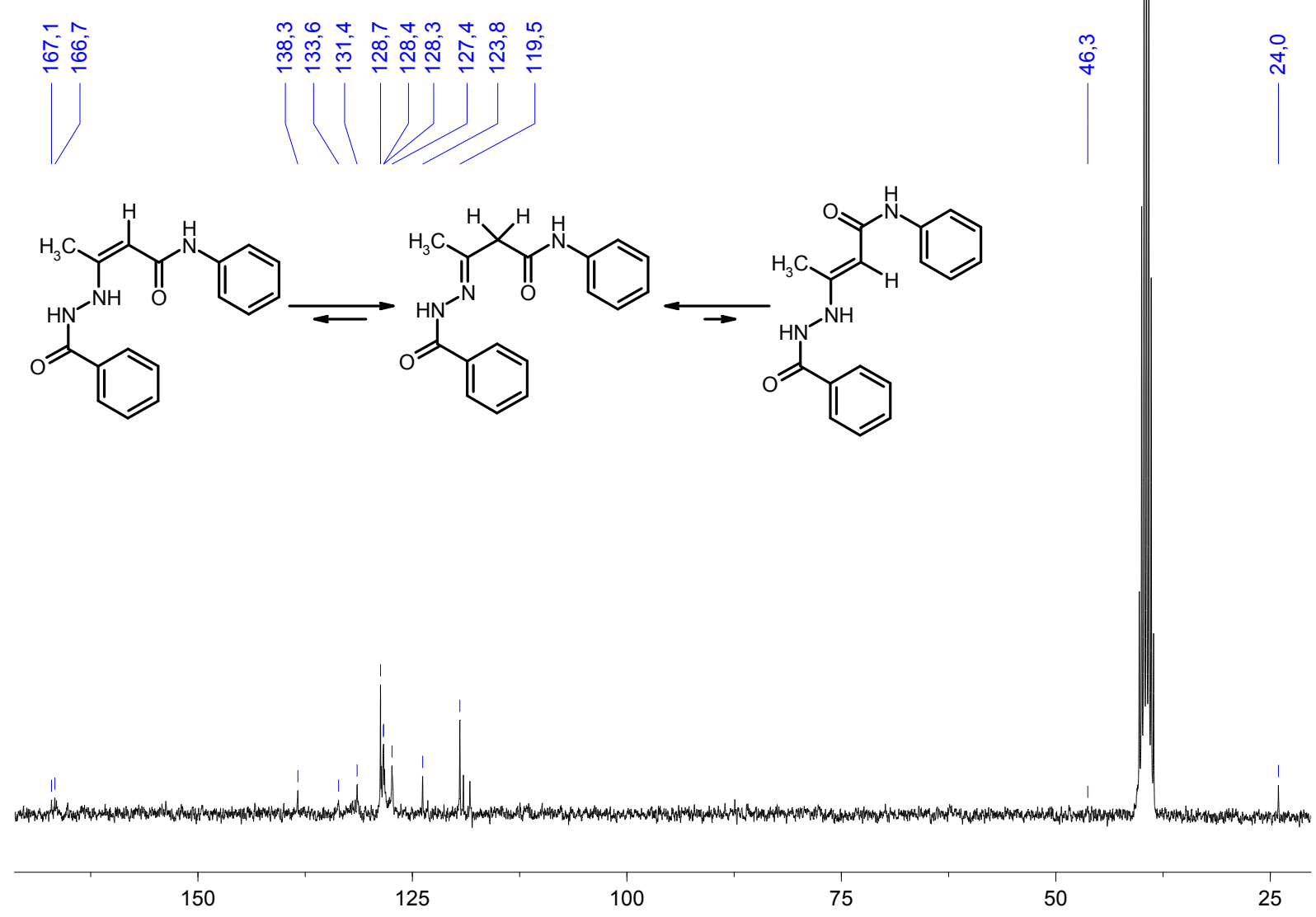

${ }^{13} \mathrm{C}\left\{{ }^{1} \mathrm{H}\right\}$ NMR $\left(\mathrm{C}_{2} \mathrm{D}_{6} \mathrm{OS}, 75 \mathrm{MHz}\right)$ spectrum of A1B1 


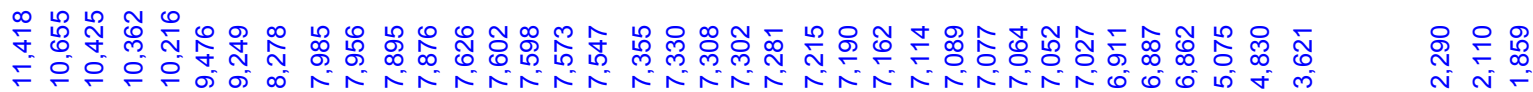

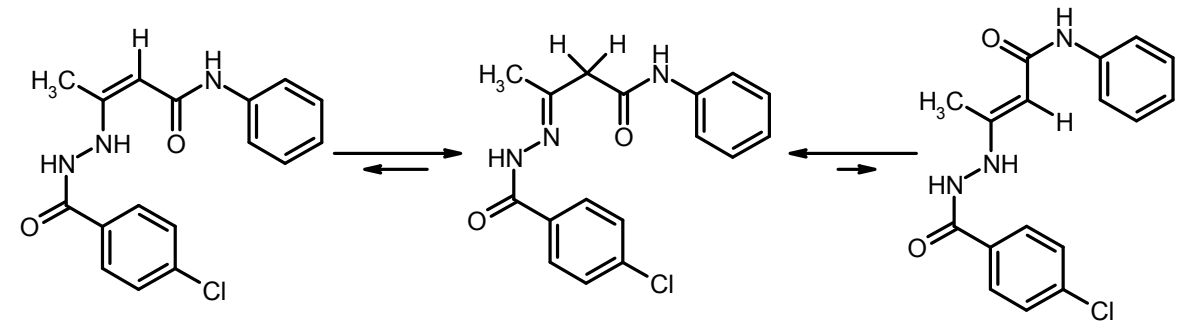

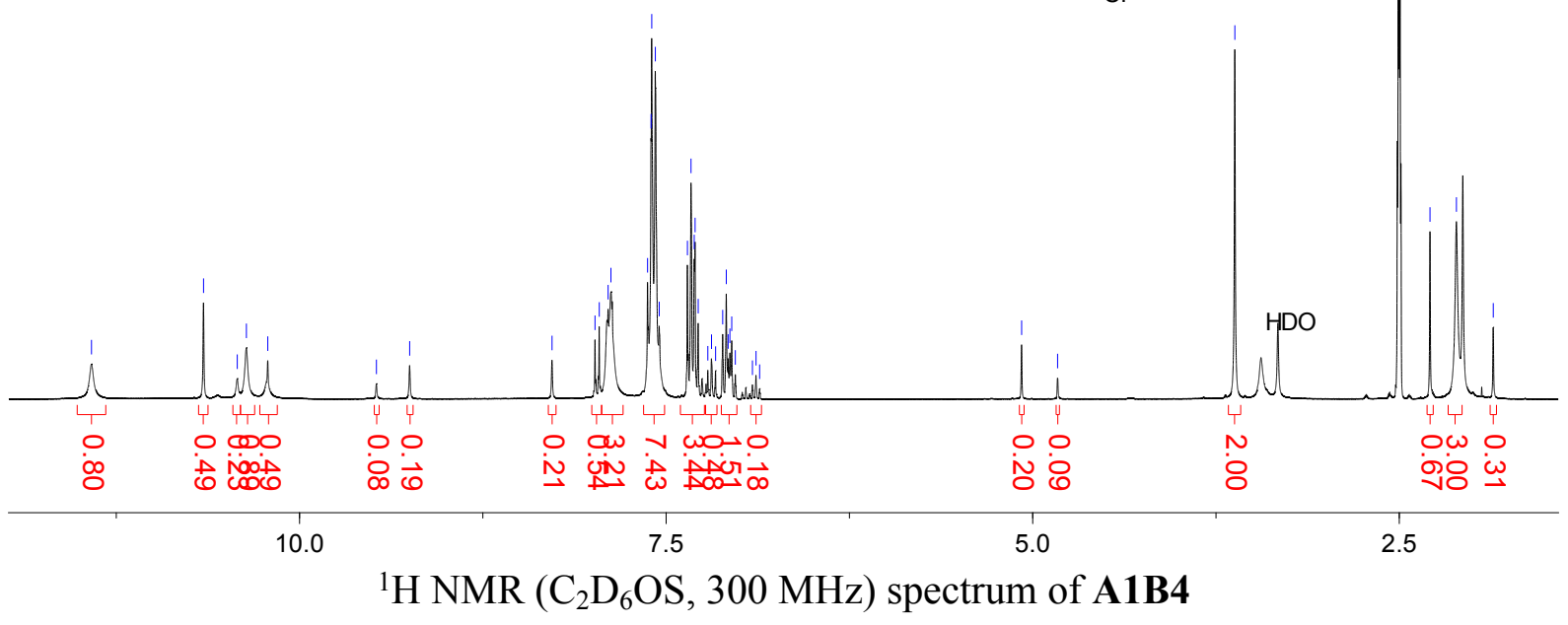




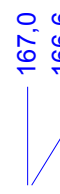

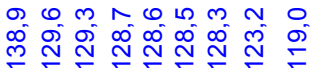

送
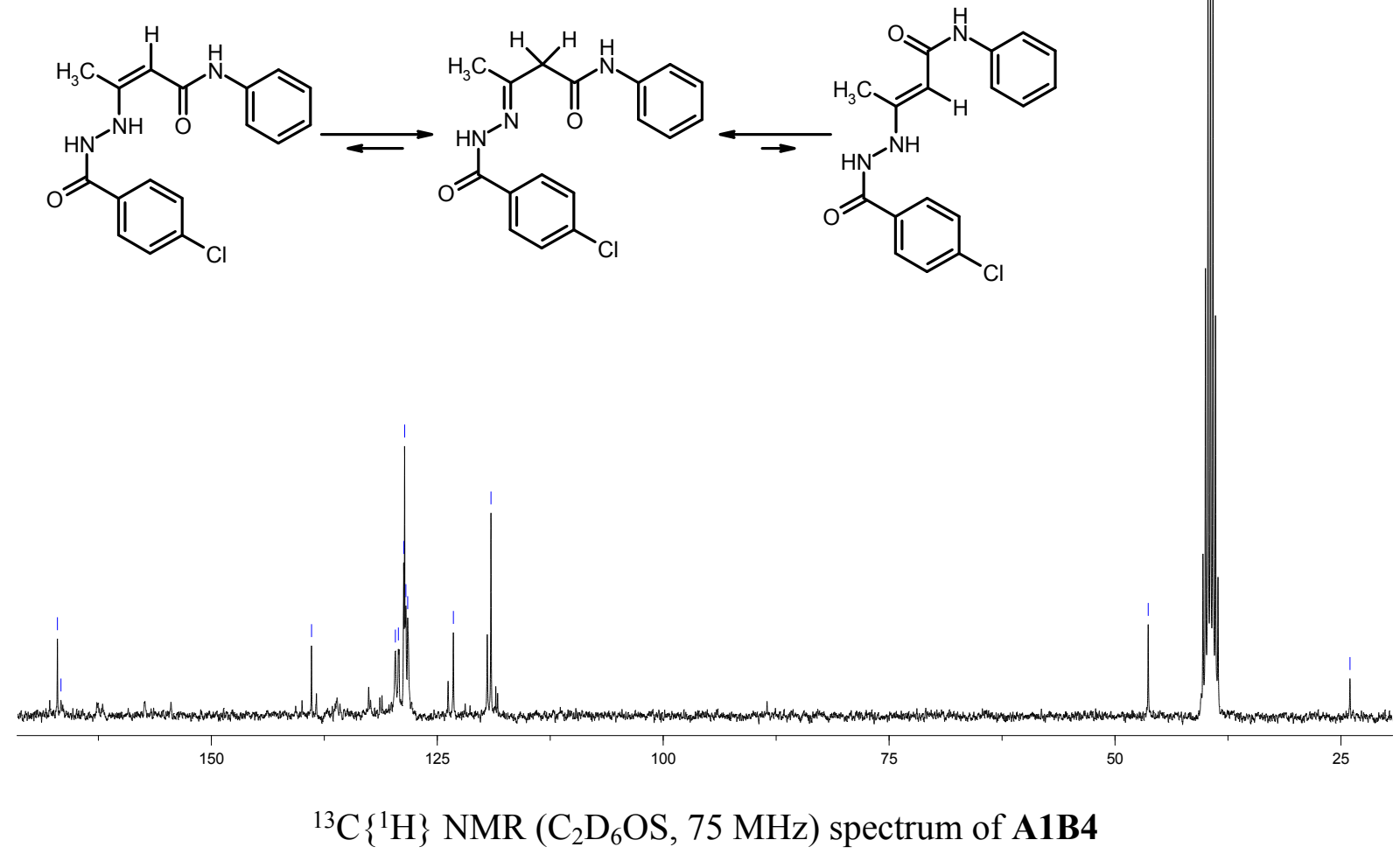
The main imine forms of A1B1 and A1B4 exist in DMSO- $\mathrm{d}_{6}$ solution in equilibrium with two tautomeric enamine forms: geometric isomers $\mathrm{Z}$ and $\mathrm{E}$ (cis and trans). As a consequence NMR spectra of A1B1 and A1B4 exhibit a mixture of three different species. Poor solubility of A1B1 and A1B4 in deuterated solvents allowed us to analyze only signals assigned to main imine forms. According to the ${ }^{1} \mathrm{H}$ NMR data we estimated isomers ratio for A1B1 to $5: 1$ : 0.4 (imine : cis enamine : trans enamine) and for A1B4 to $5: 1: 0.5$ (imine : cis enamine : trans enamine).

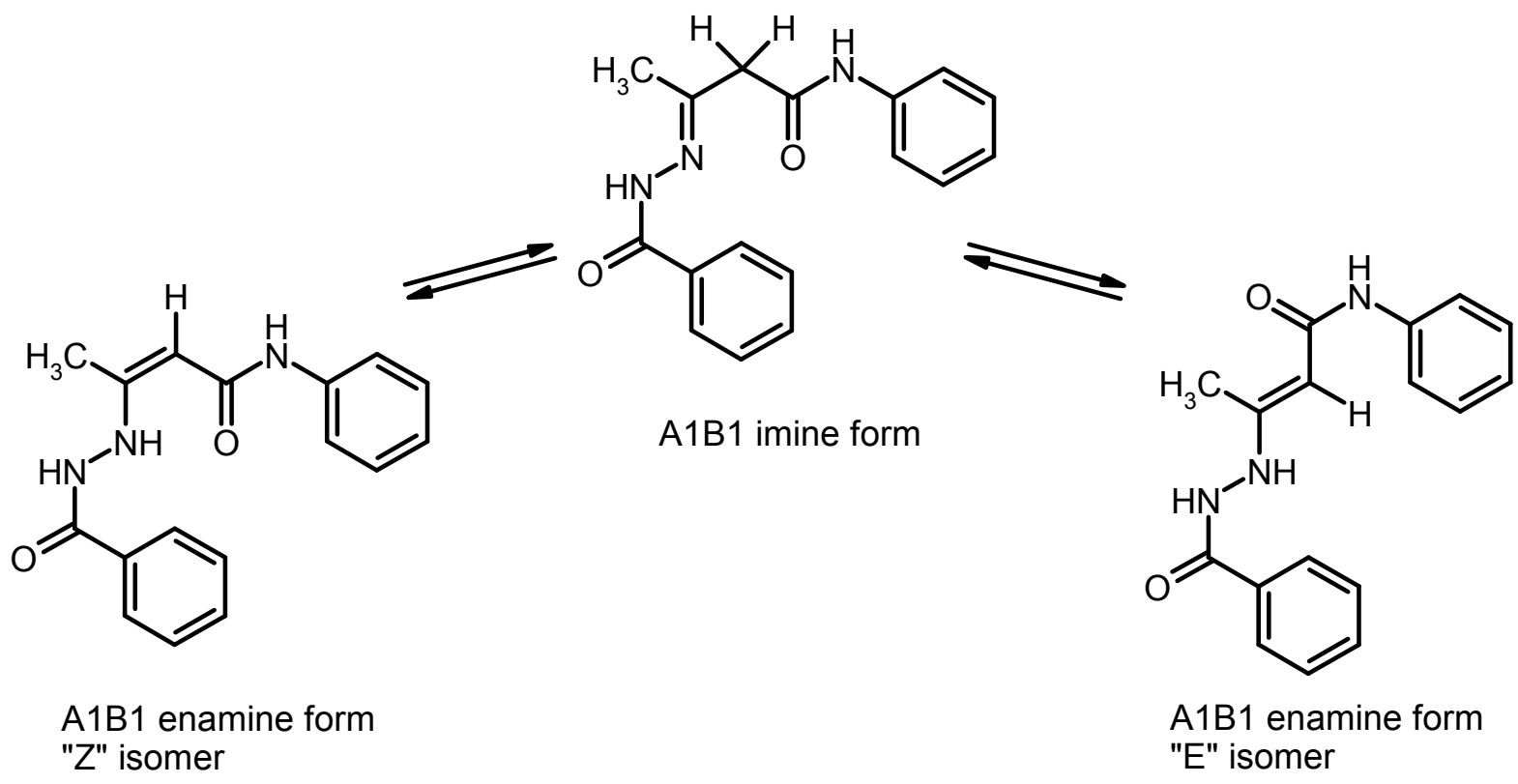

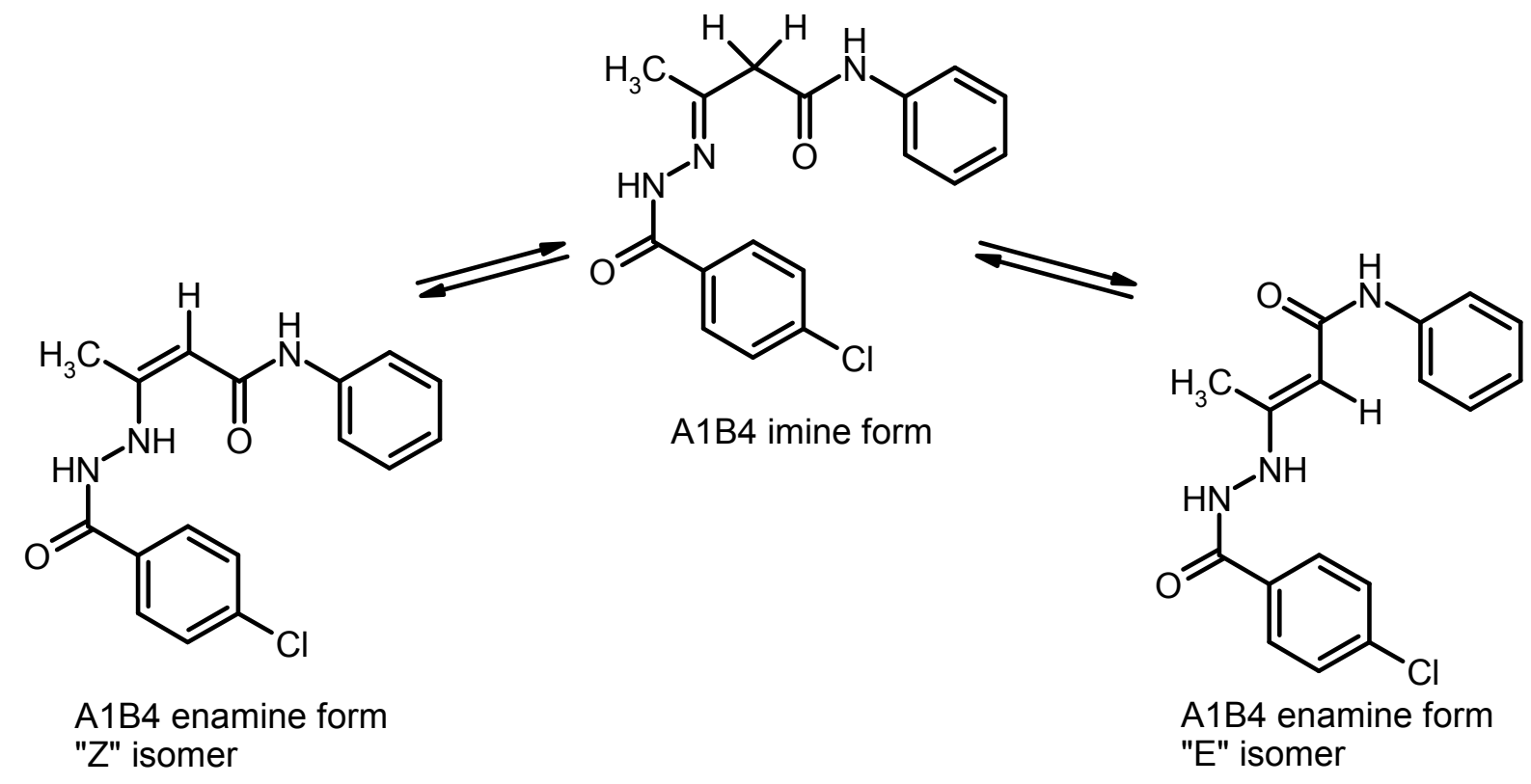


List of signal shifts in the compounds $1-19{ }^{1} \mathrm{H}$ NMR spectra

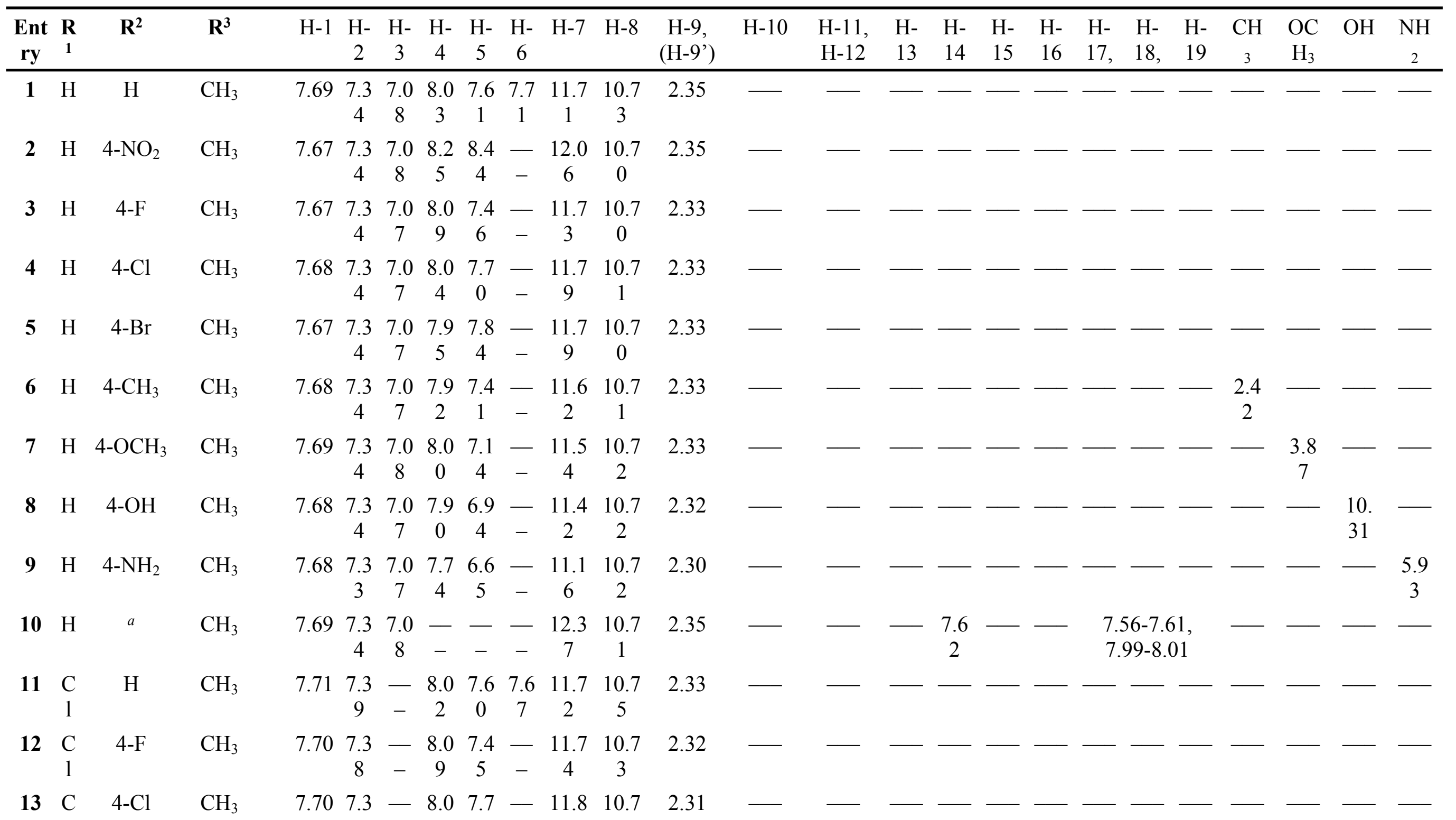




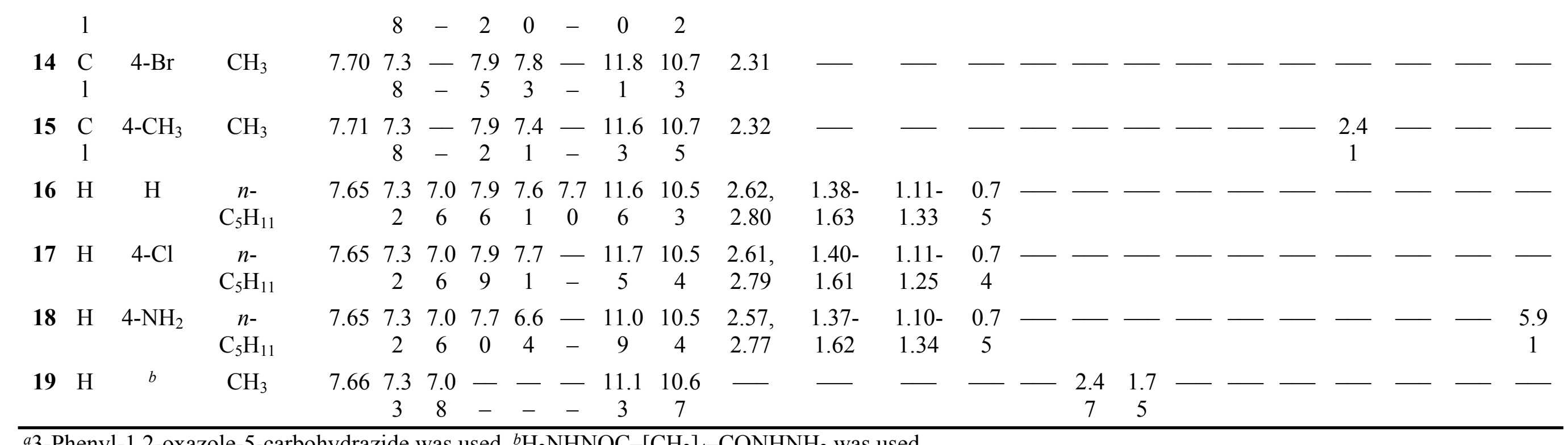

a3-Phenyl-1,2-oxazole-5-carbohydrazide was used. ${ }^{b} \mathrm{H}_{2} \mathrm{NHNOC}-\left[\mathrm{CH}_{2}\right]_{4}-\mathrm{CONHNH}_{2}$ was used.

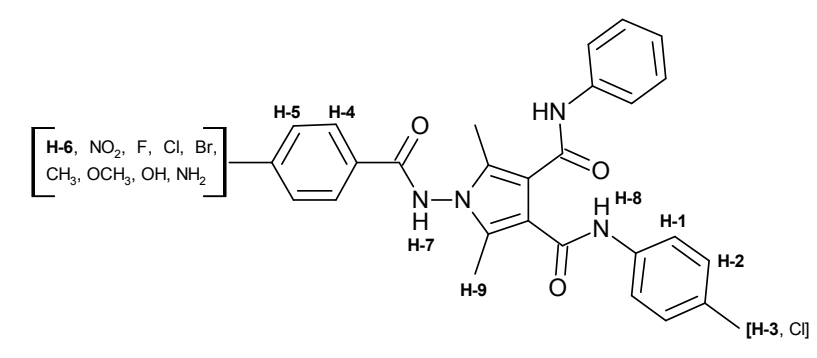

1-9, 11-15

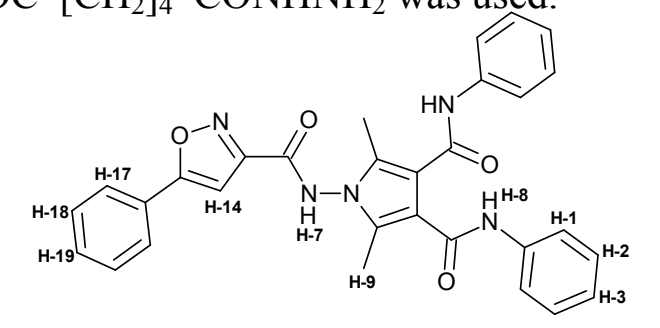

10

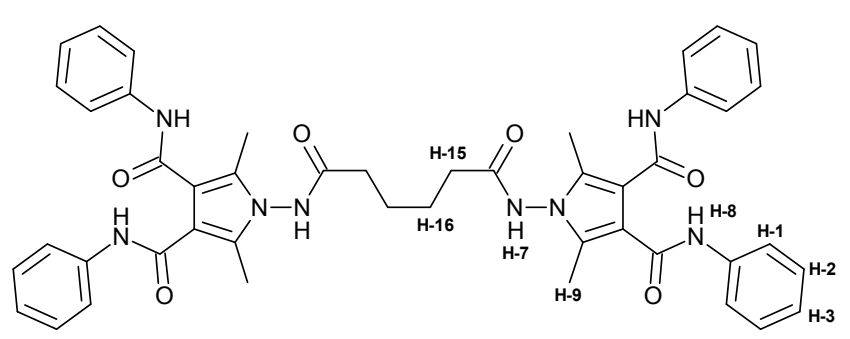

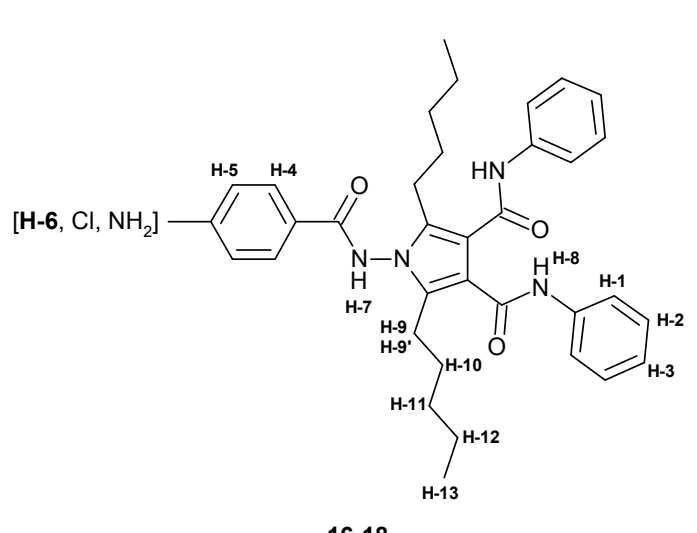

16-18 


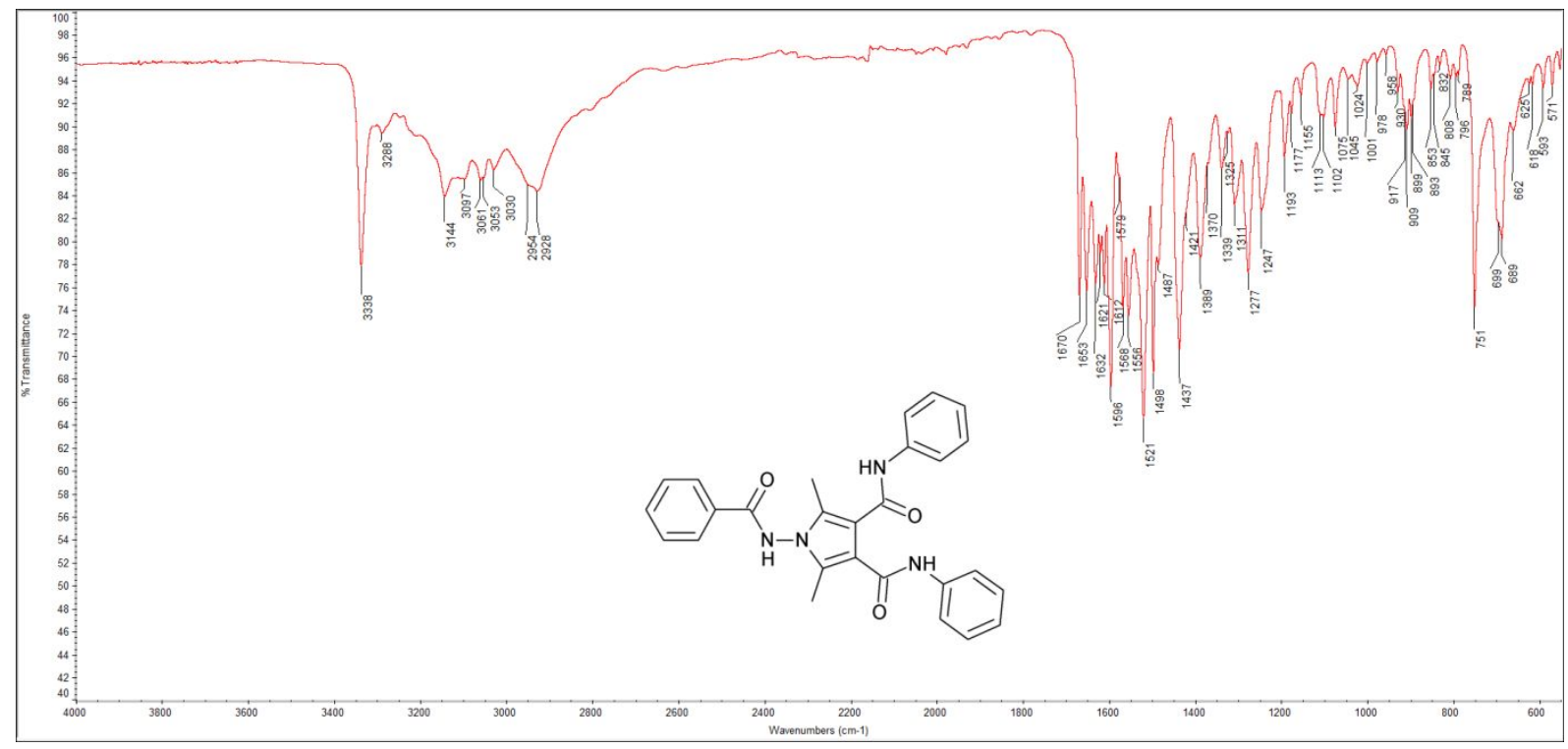

IR spectrum of $1\left(4000-550 \mathrm{~cm}^{-1}\right)$

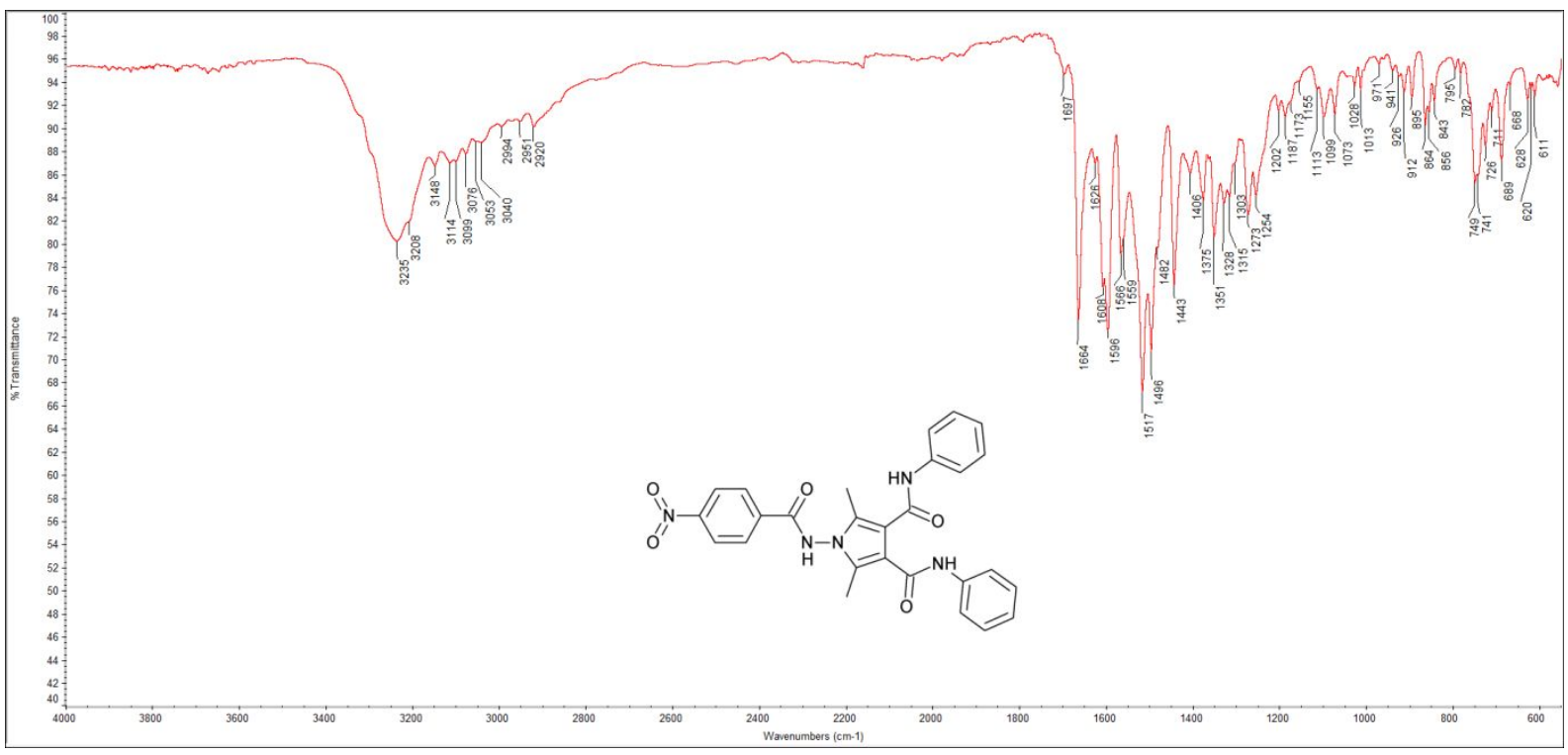

IR spectrum of $2\left(4000-550 \mathrm{~cm}^{-1}\right)$ 


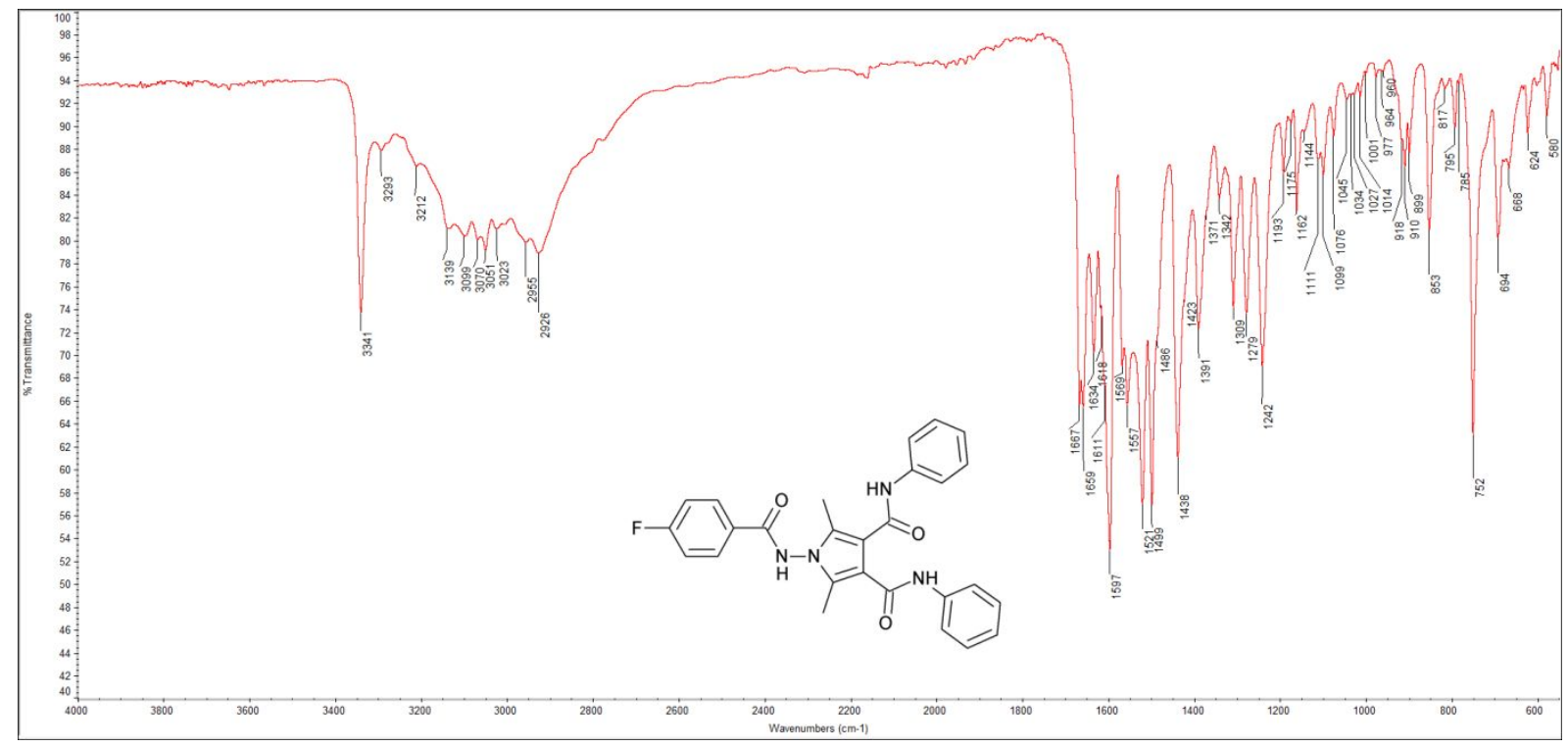

IR spectrum of $3\left(4000-550 \mathrm{~cm}^{-1}\right)$

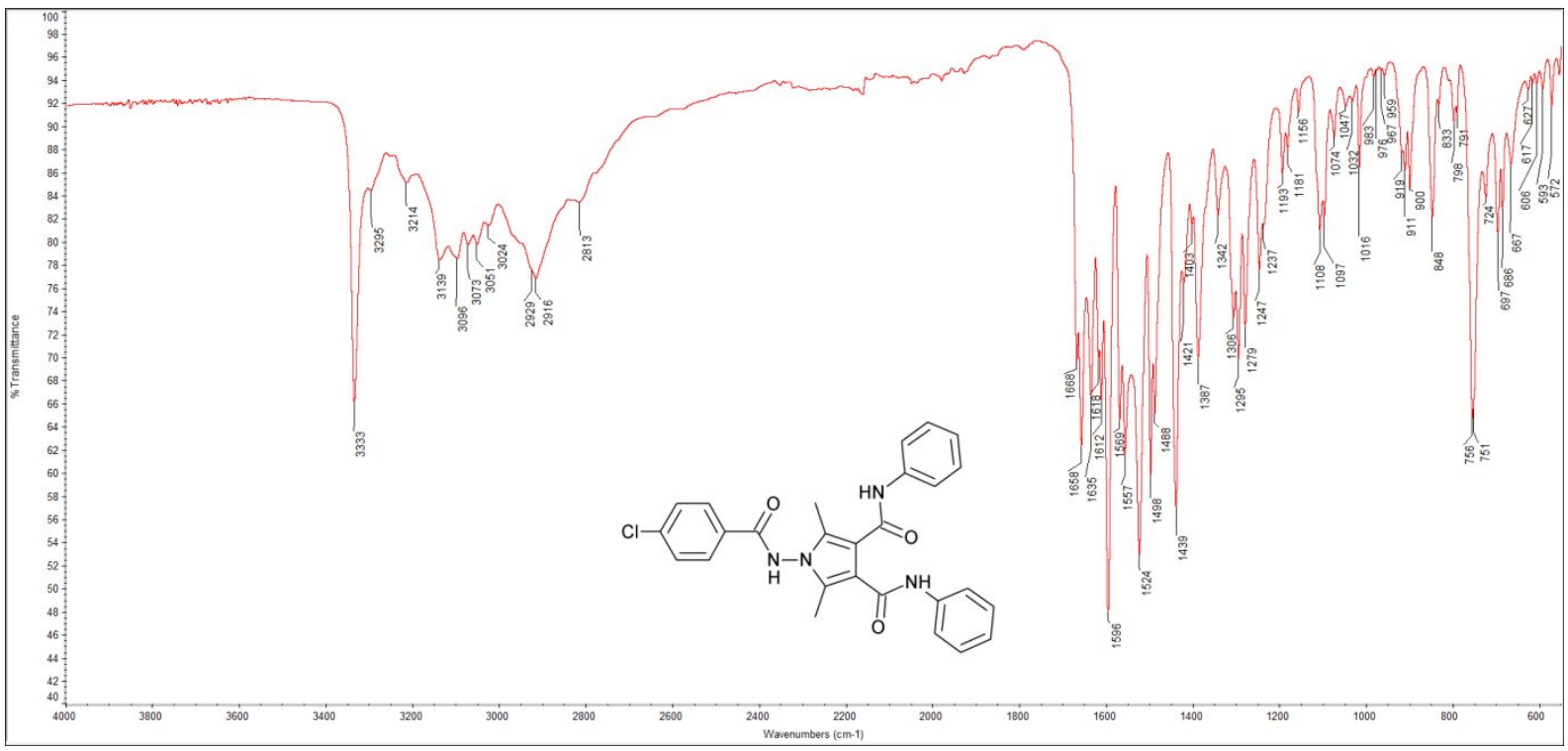

IR spectrum of $4\left(4000-550 \mathrm{~cm}^{-1}\right)$ 


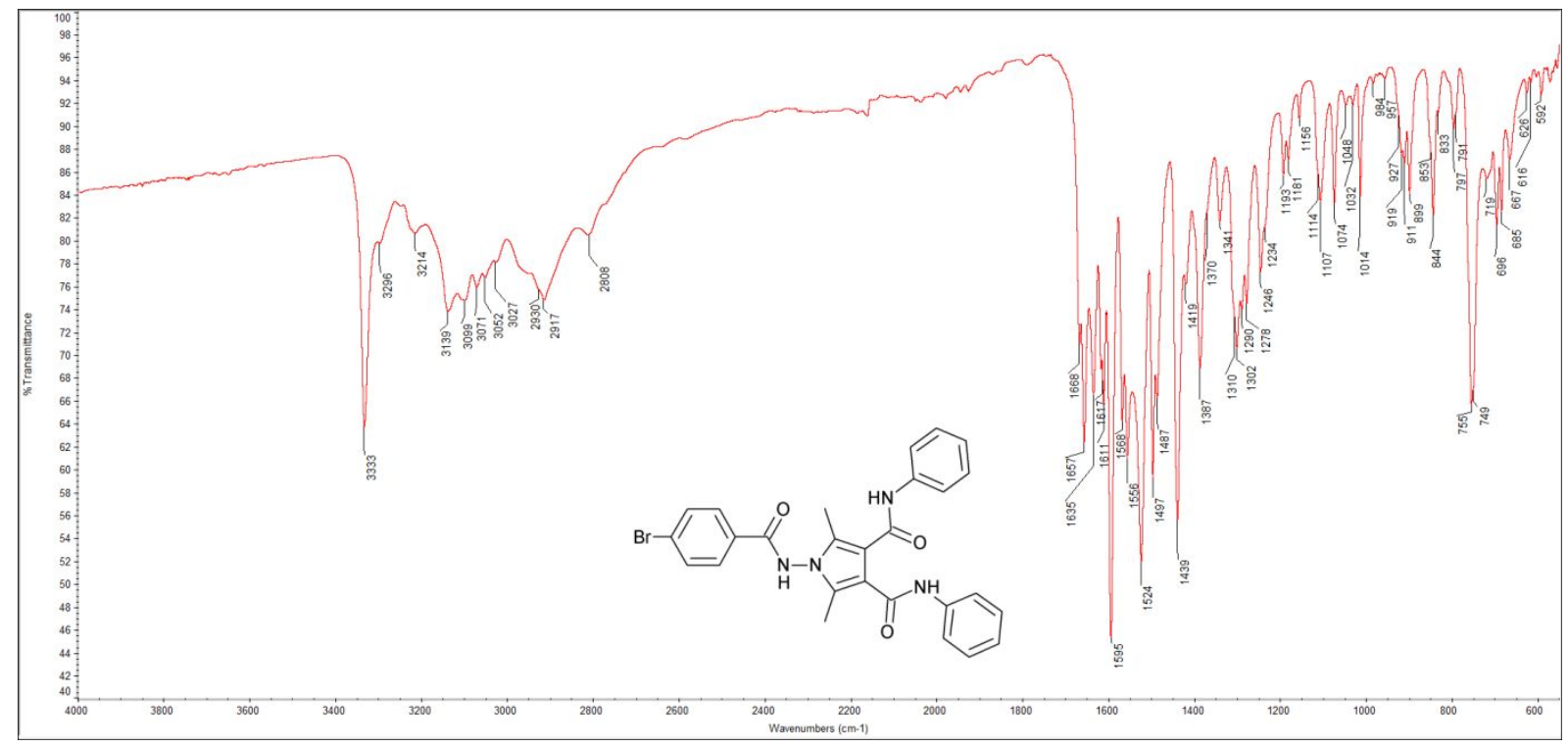

IR spectrum of $5\left(4000-550 \mathrm{~cm}^{-1}\right)$

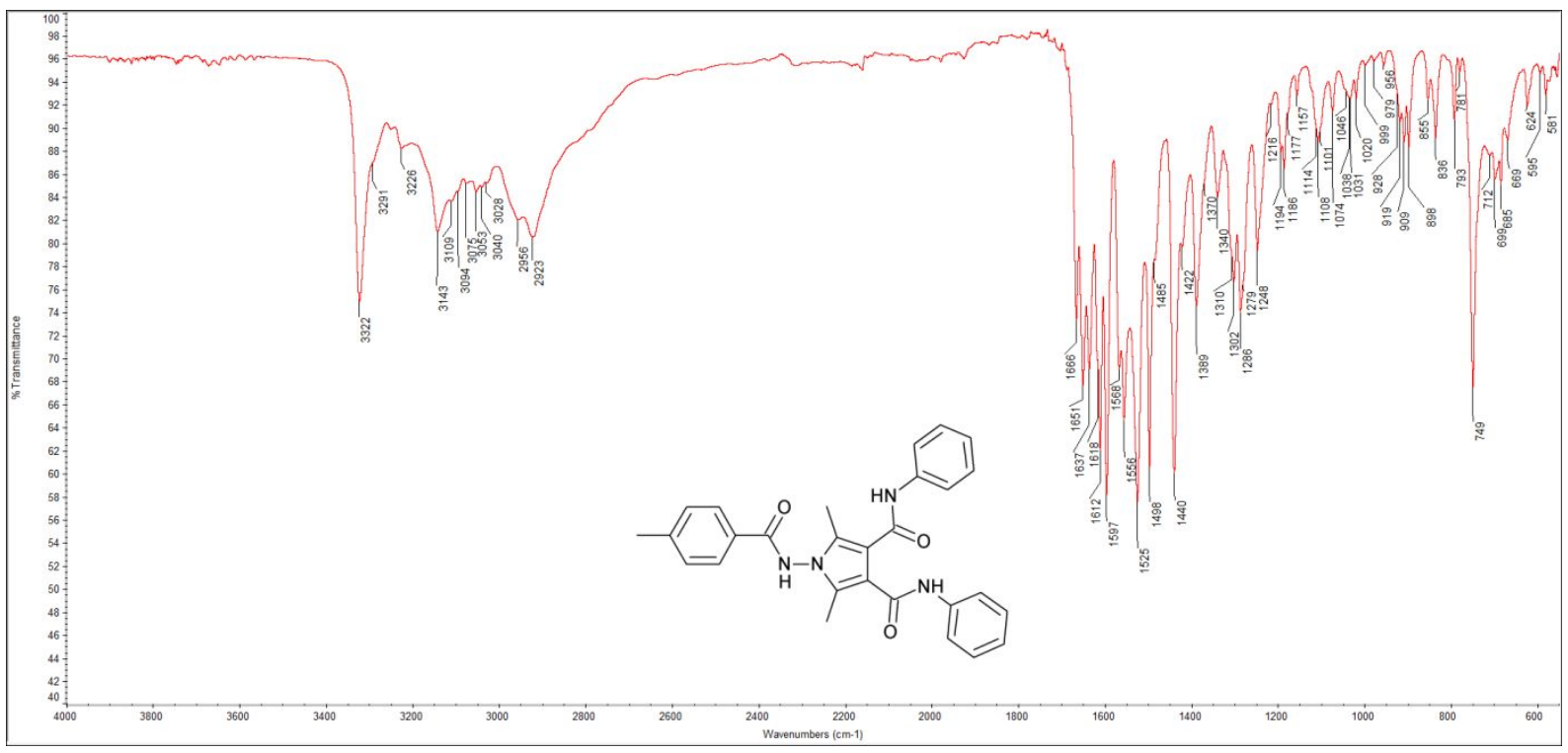

IR spectrum of $6\left(4000-550 \mathrm{~cm}^{-1}\right)$ 


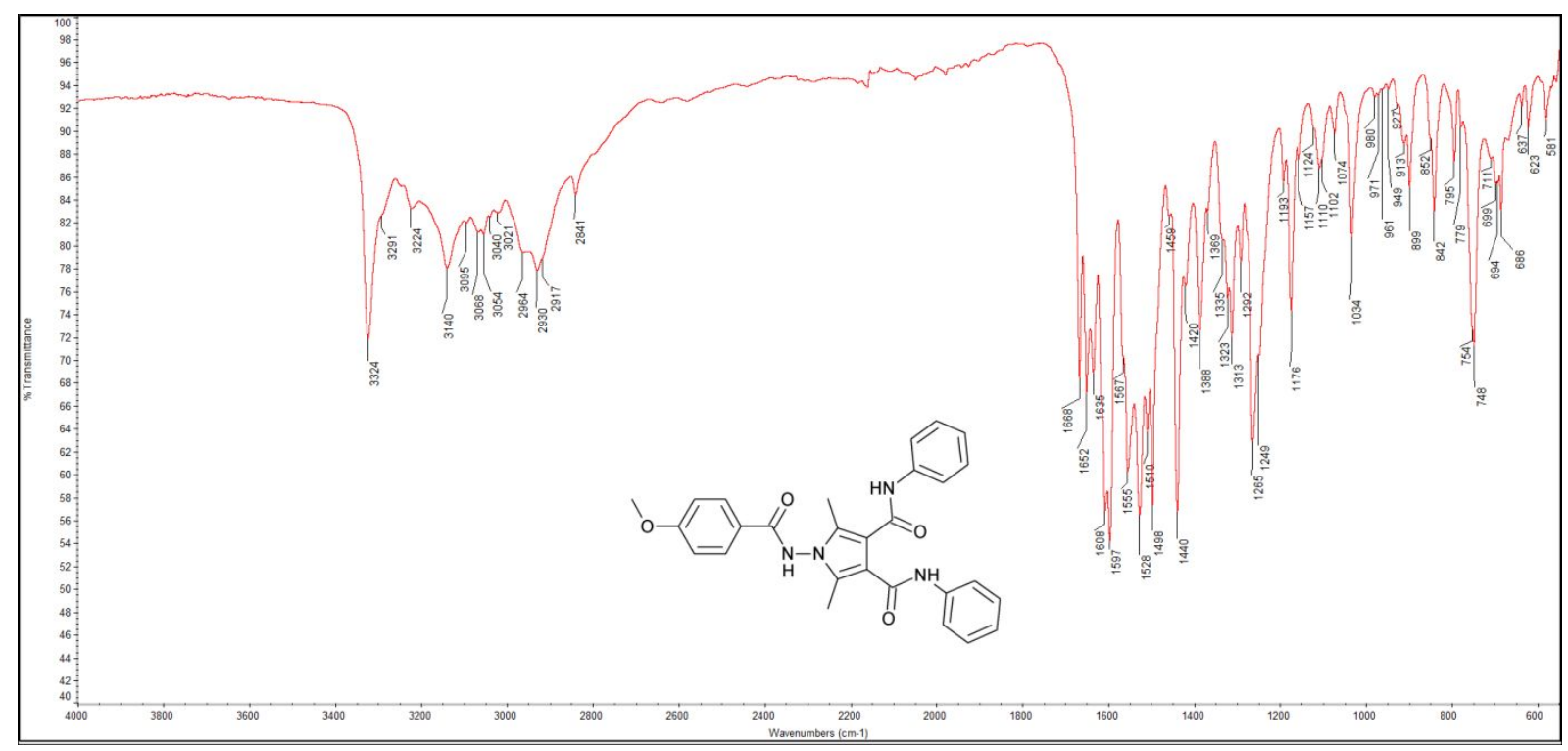

IR spectrum of $7\left(4000-550 \mathrm{~cm}^{-1}\right)$

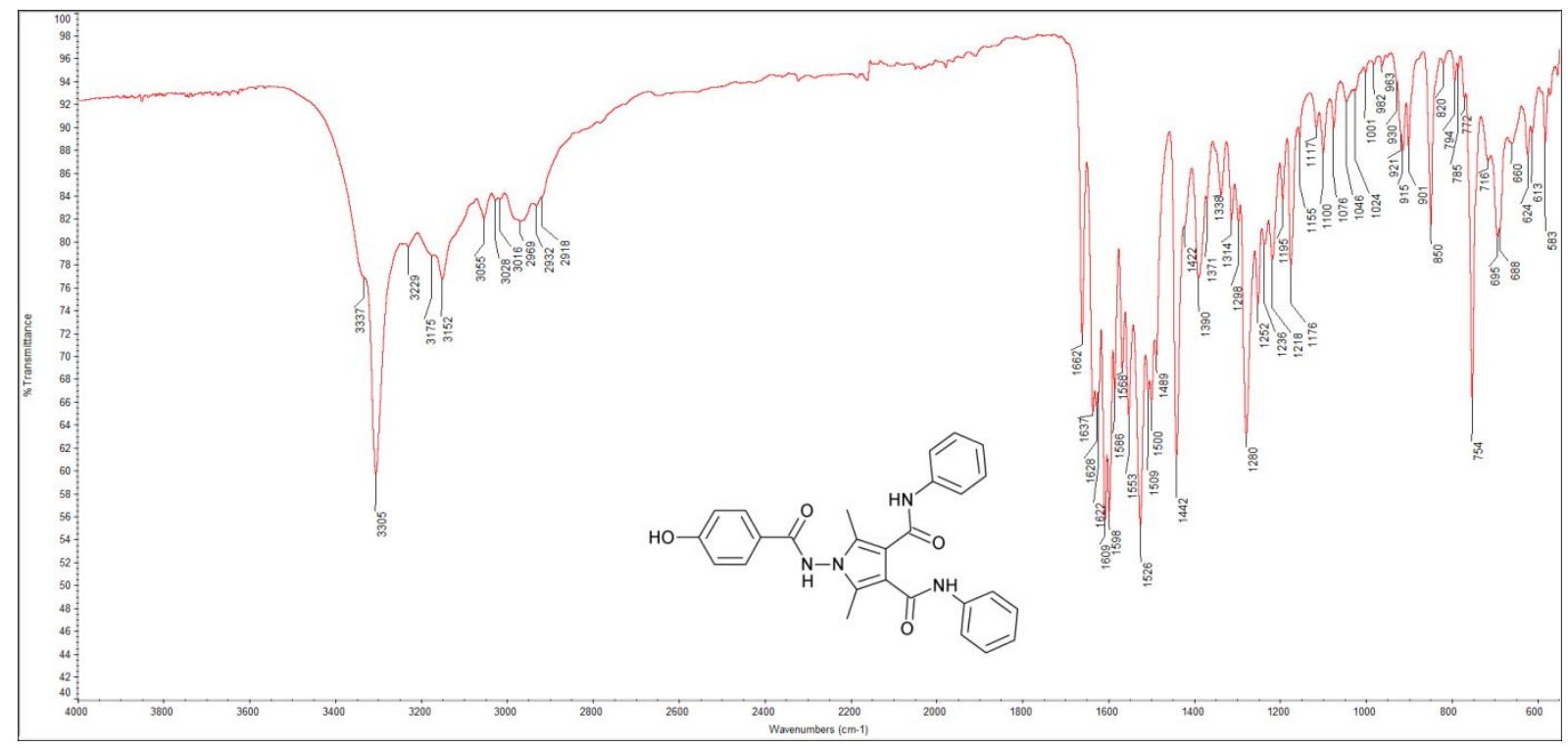

IR spectrum of $8\left(4000-550 \mathrm{~cm}^{-1}\right)$ 


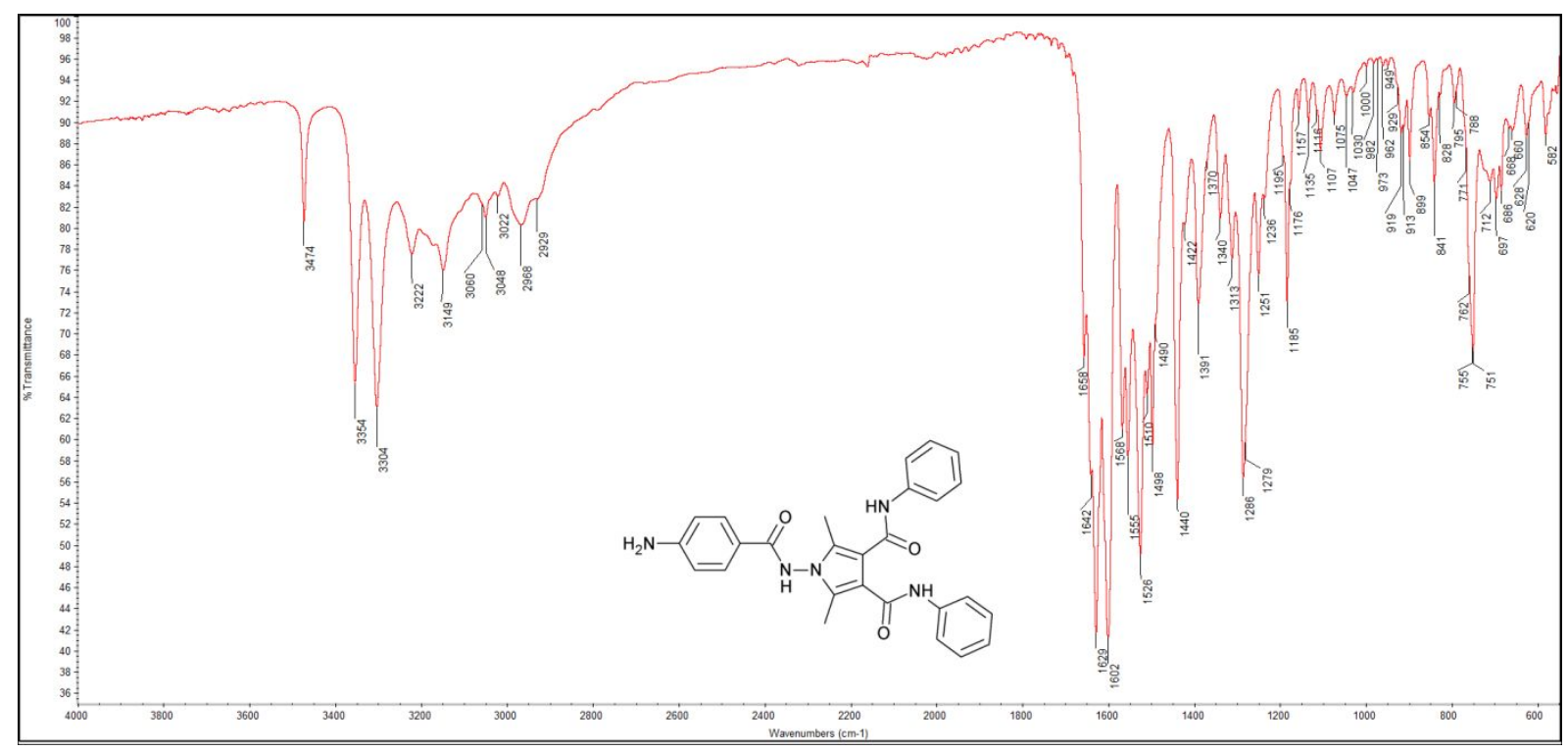

IR spectrum of $9\left(4000-550 \mathrm{~cm}^{-1}\right)$

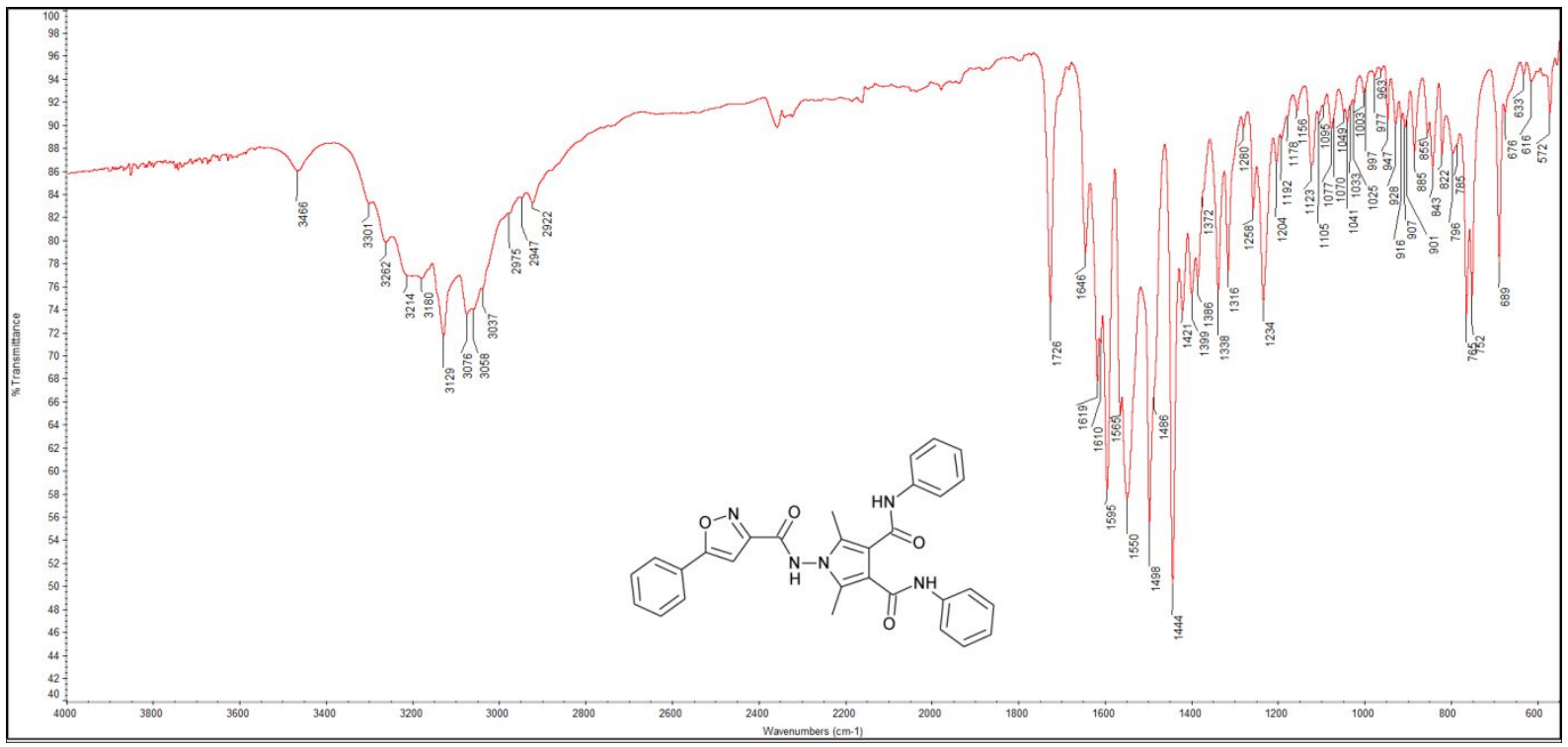

IR spectrum of $10\left(4000-550 \mathrm{~cm}^{-1}\right)$ 


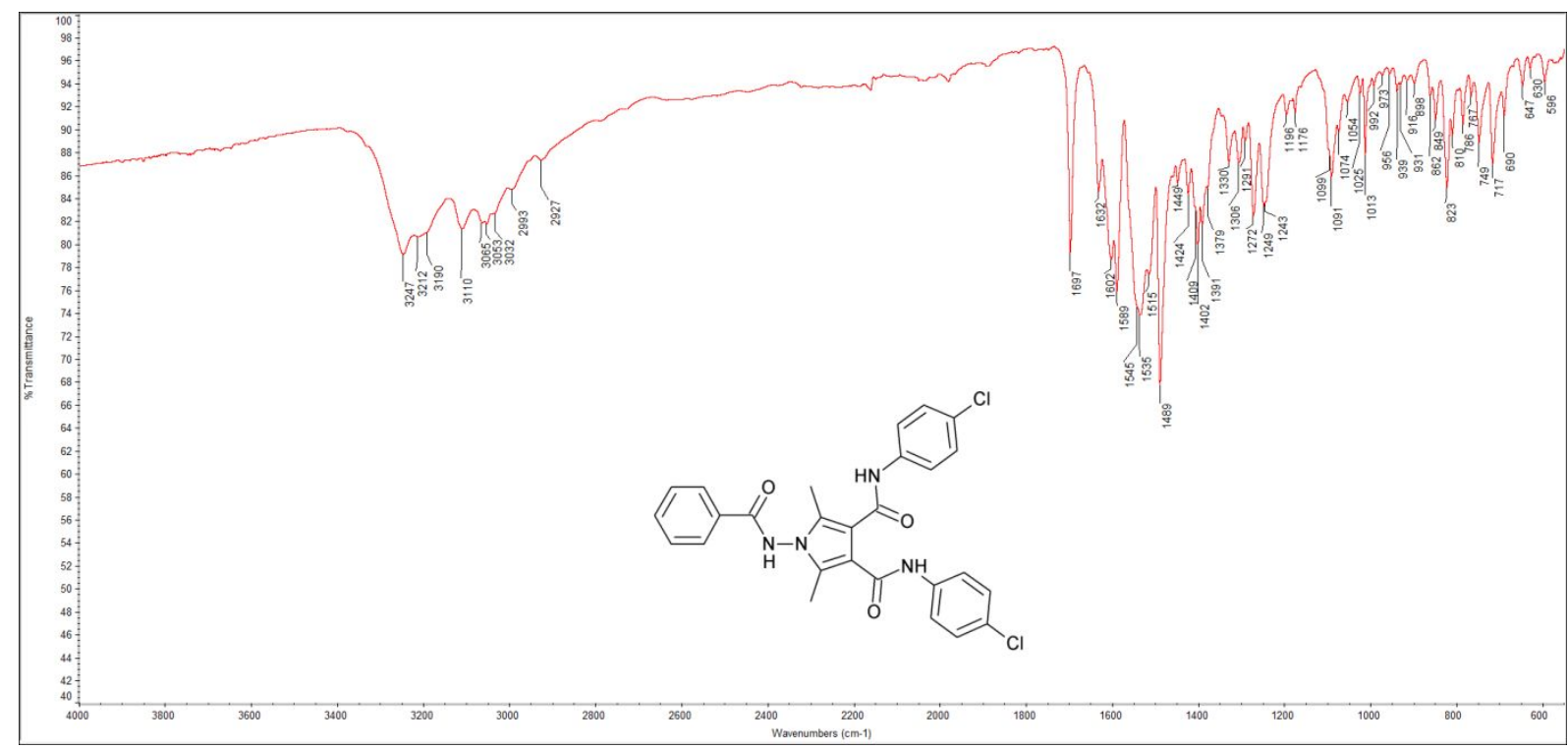

IR spectrum of $11\left(4000-550 \mathrm{~cm}^{-1}\right)$

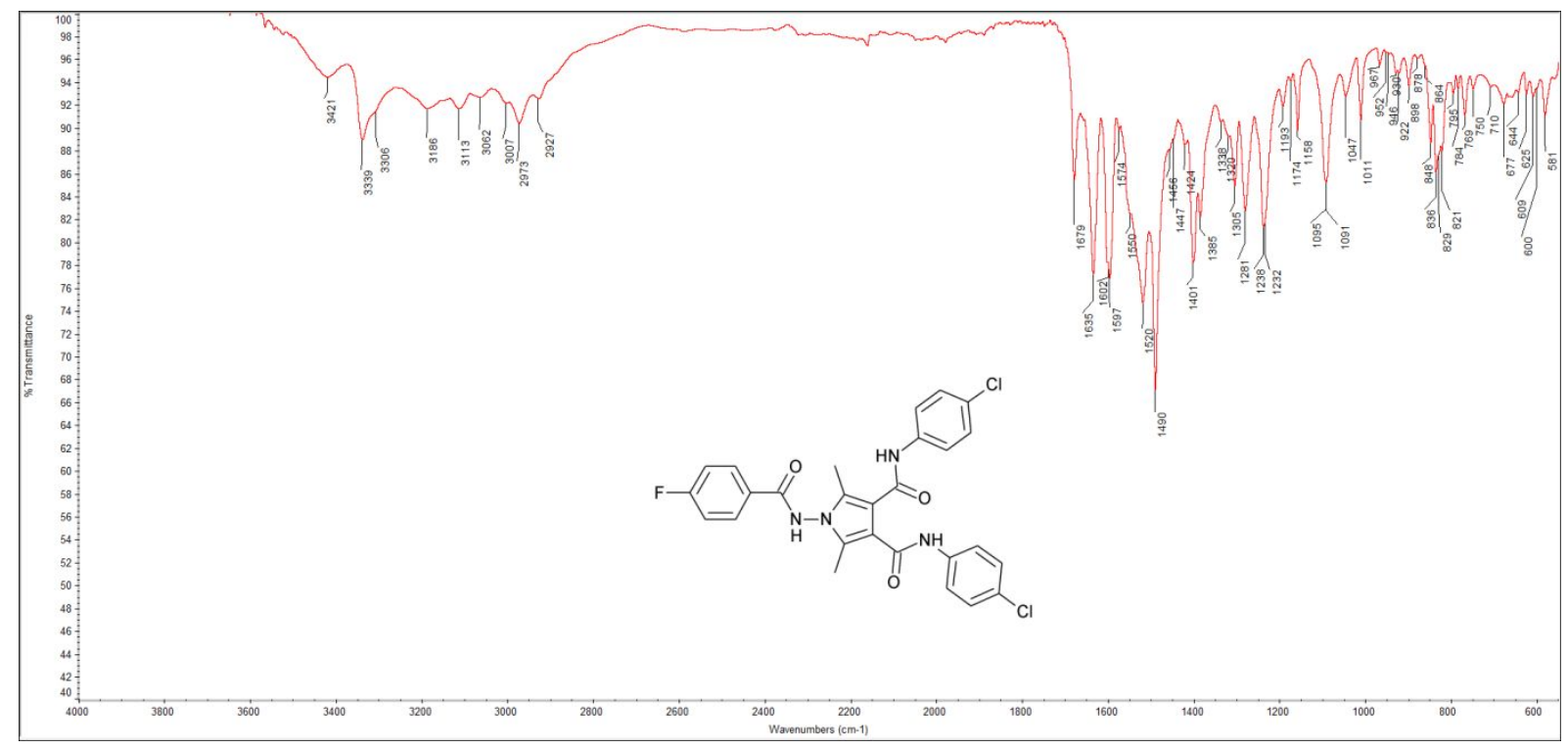

IR spectrum of $12\left(4000-550 \mathrm{~cm}^{-1}\right)$ 


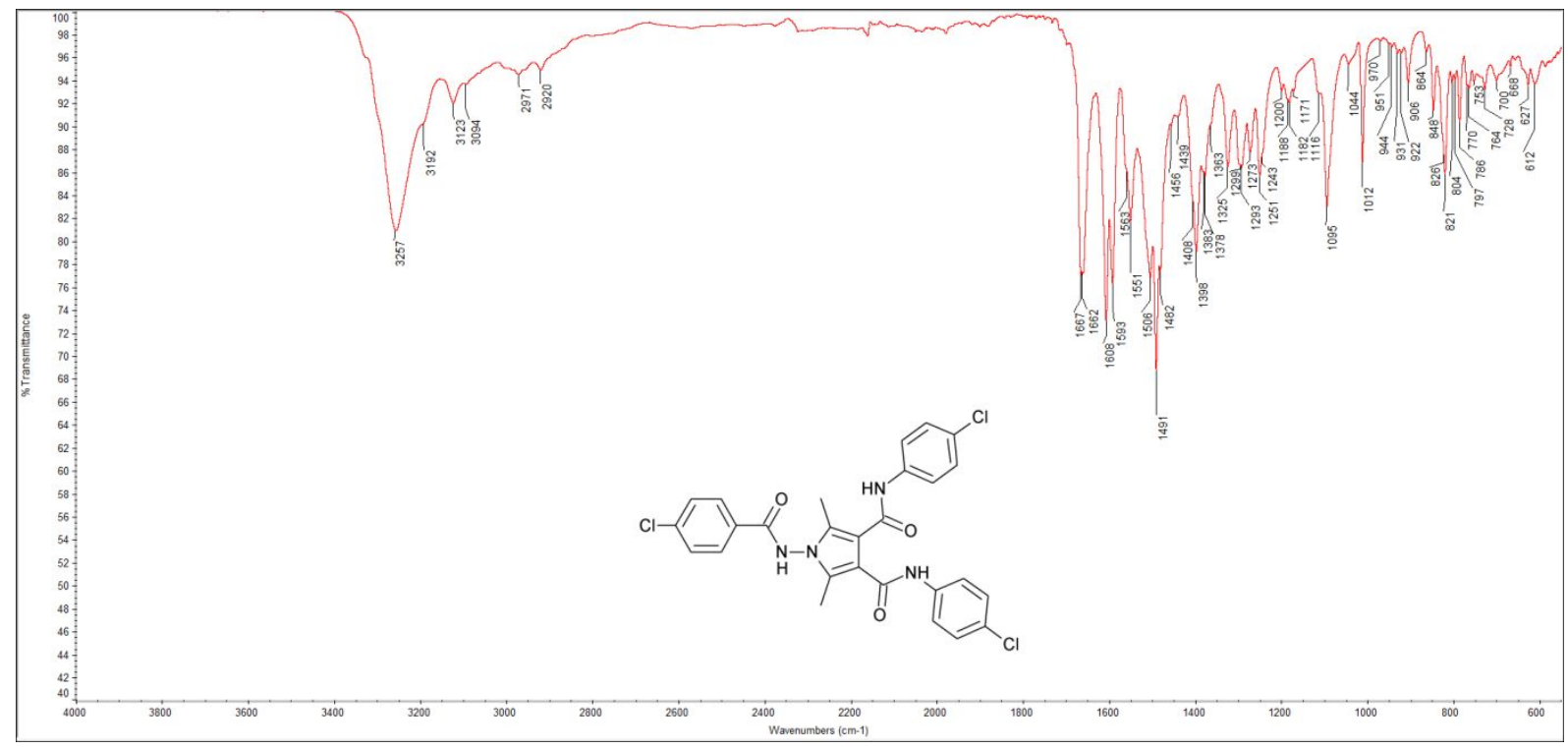

IR spectrum of $13\left(4000-550 \mathrm{~cm}^{-1}\right)$

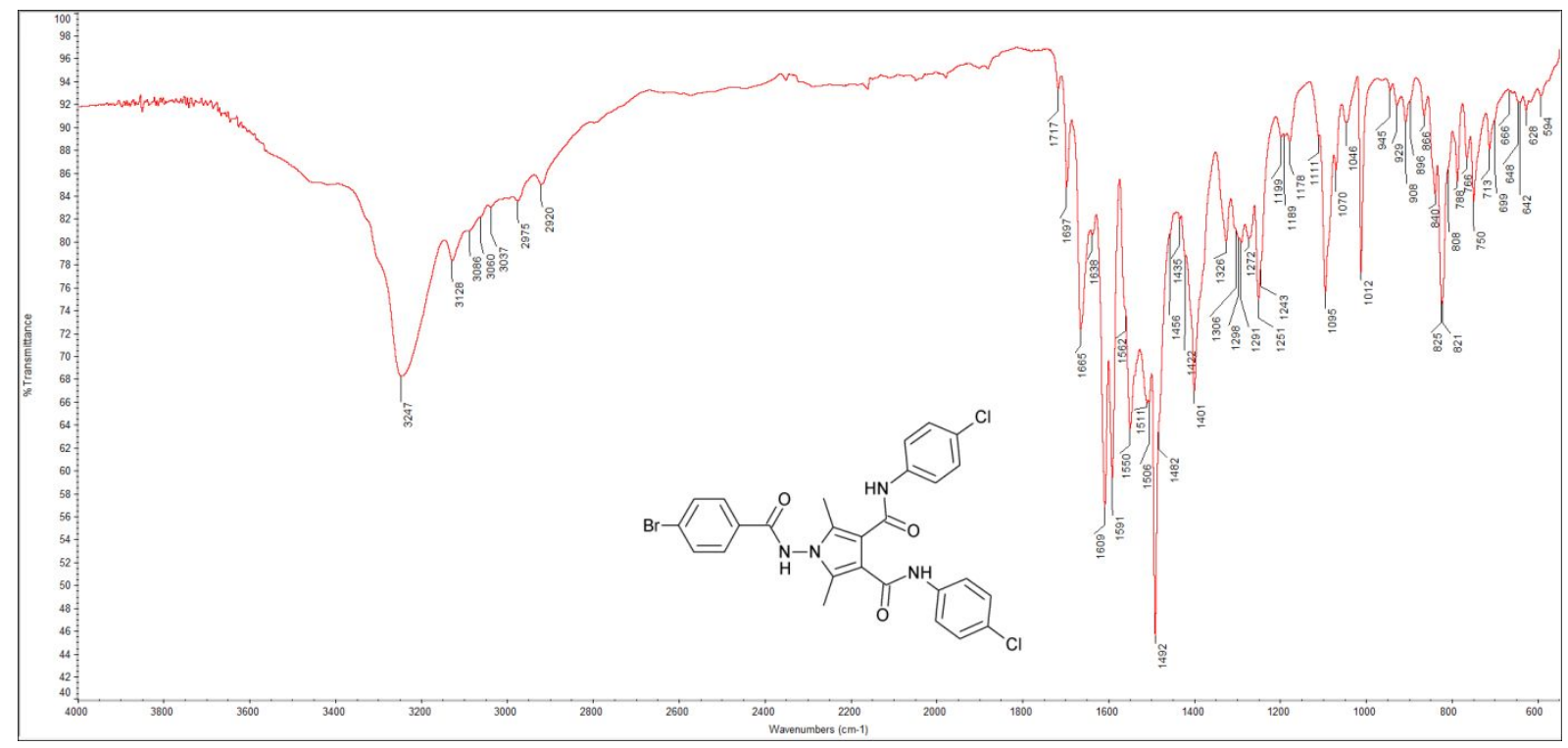

IR spectrum of $14\left(4000-550 \mathrm{~cm}^{-1}\right)$ 


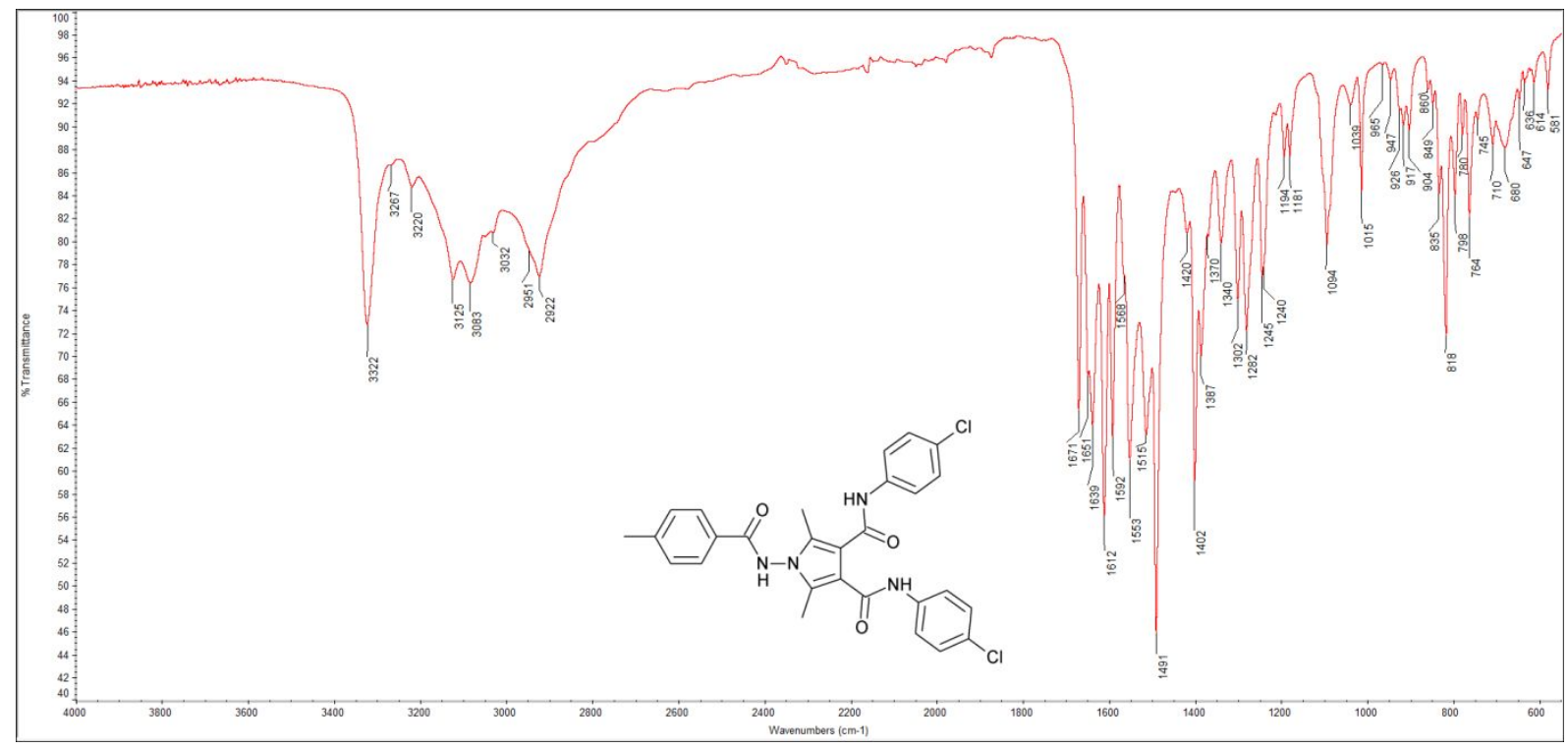

IR spectrum of $15\left(4000-550 \mathrm{~cm}^{-1}\right)$

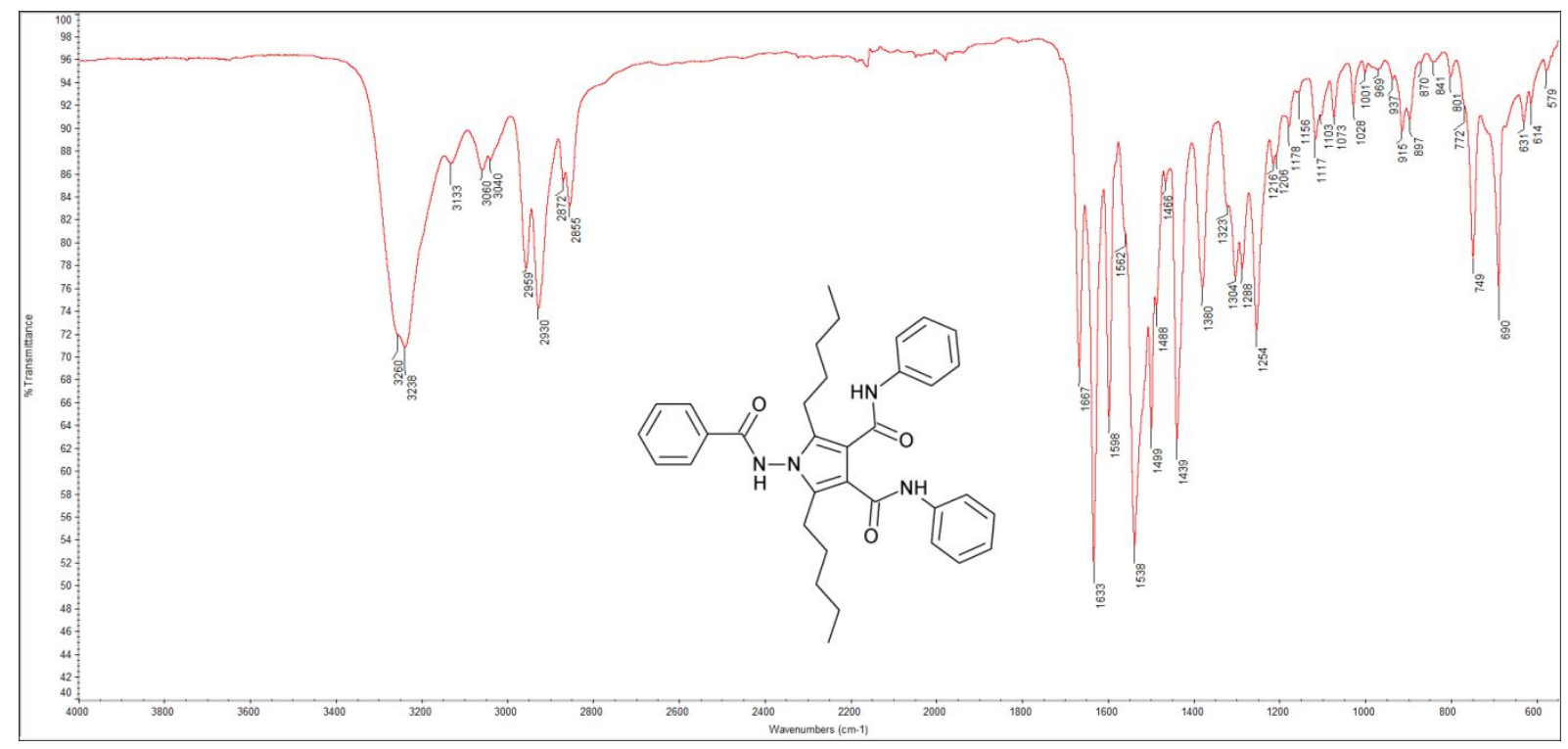

IR spectrum of $16\left(4000-550 \mathrm{~cm}^{-1}\right)$ 


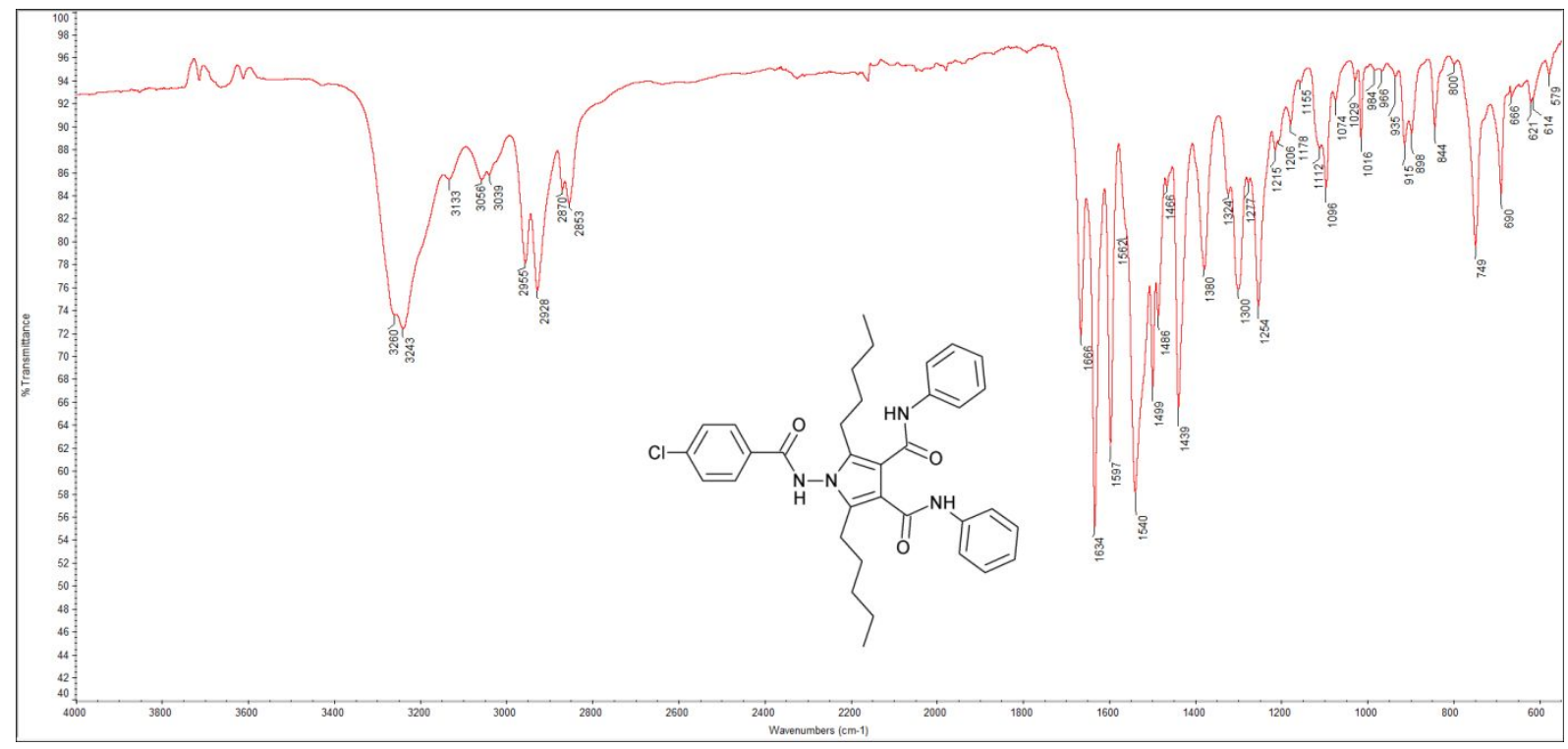

IR spectrum of $17\left(4000-550 \mathrm{~cm}^{-1}\right)$

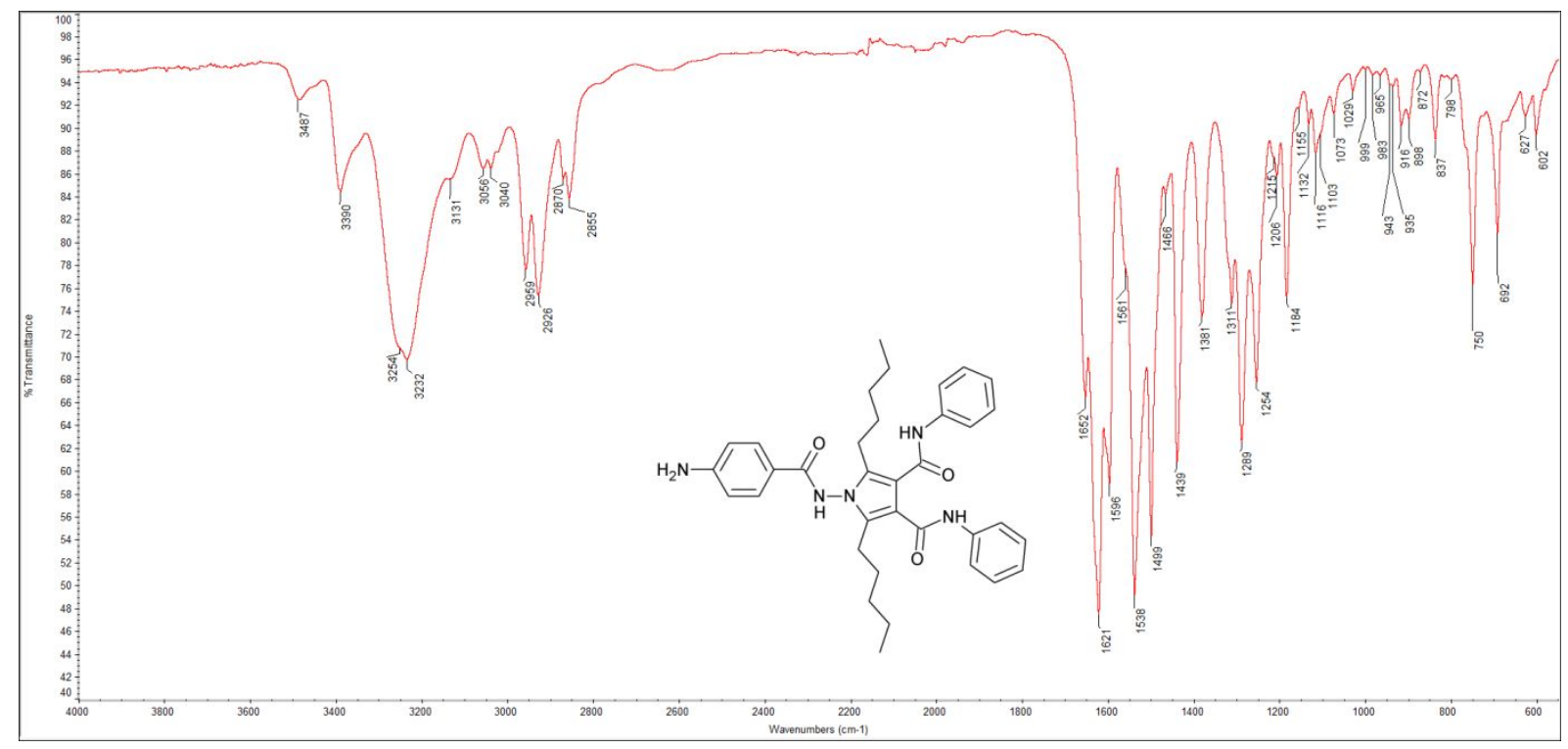

IR spectrum of $18\left(4000-550 \mathrm{~cm}^{-1}\right)$ 


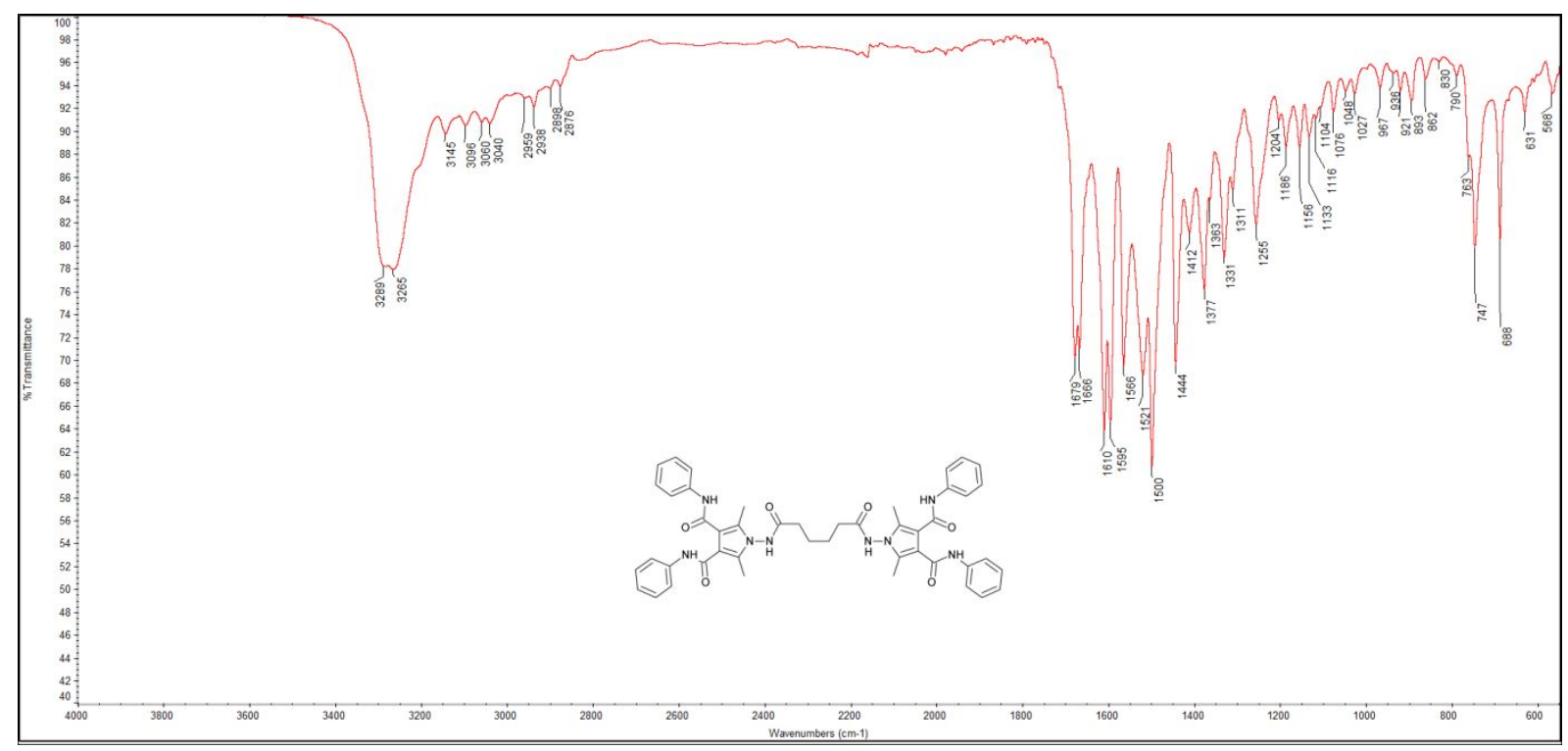

IR spectrum of $19\left(4000-550 \mathrm{~cm}^{-1}\right)$

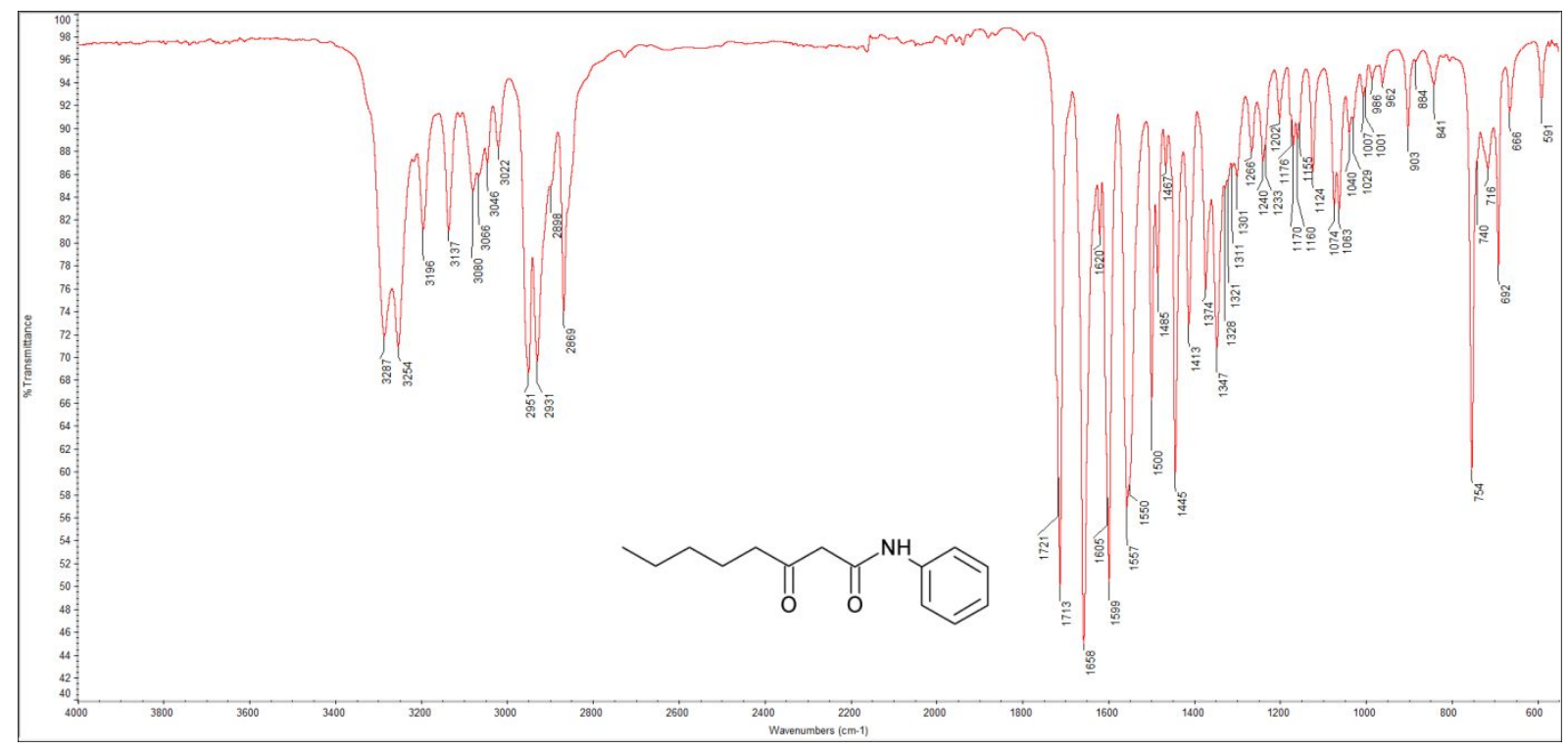

IR spectrum of A3 (4000-550 $\left.\mathrm{cm}^{-1}\right)$ 


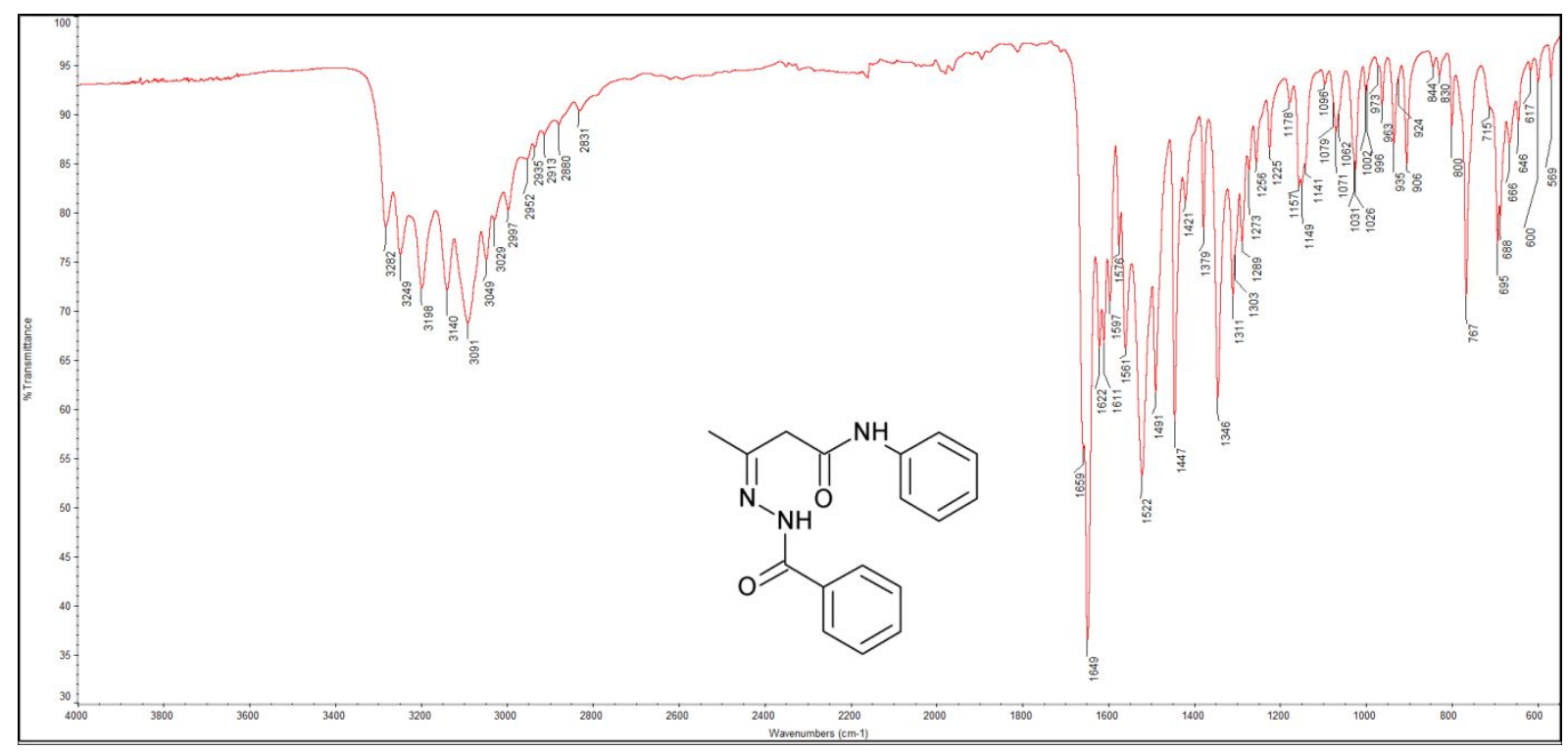

IR spectrum of A1B1 (4000-550 $\left.\mathrm{cm}^{-1}\right)$

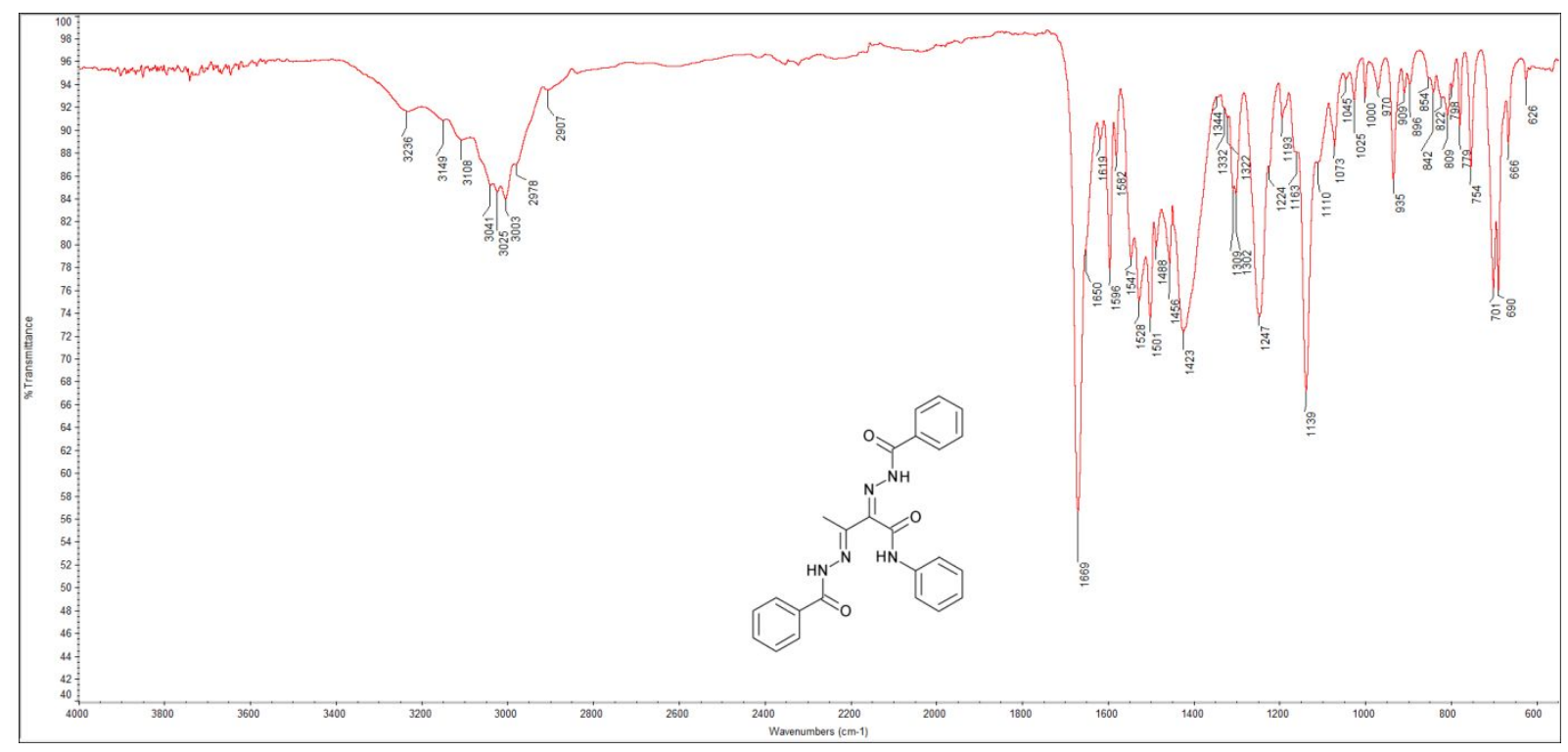

IR spectrum of $\mathbf{C 1}\left(4000-550 \mathrm{~cm}^{-1}\right)$ 


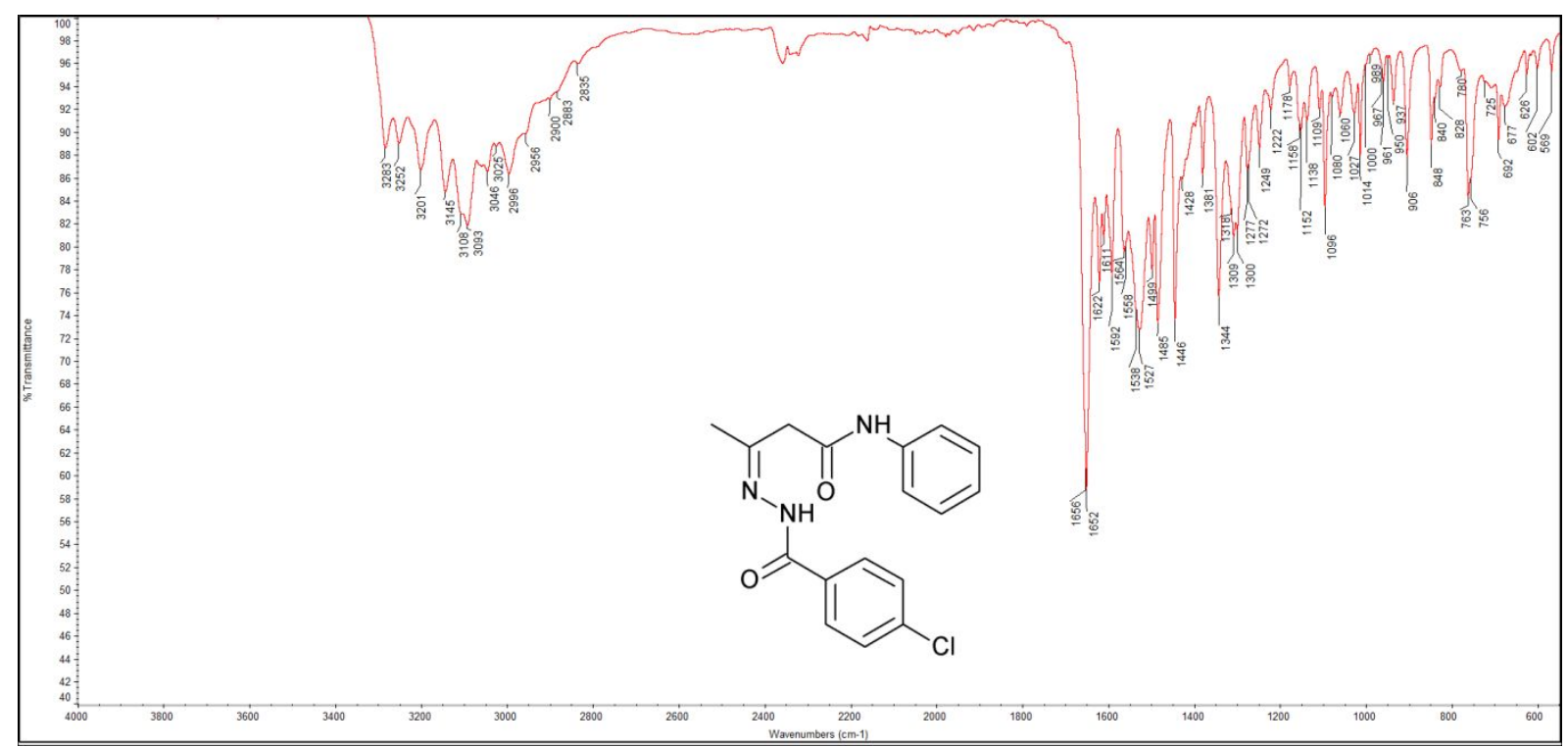

IR spectrum of A1B4 (4000-550 $\left.\mathrm{cm}^{-1}\right)$

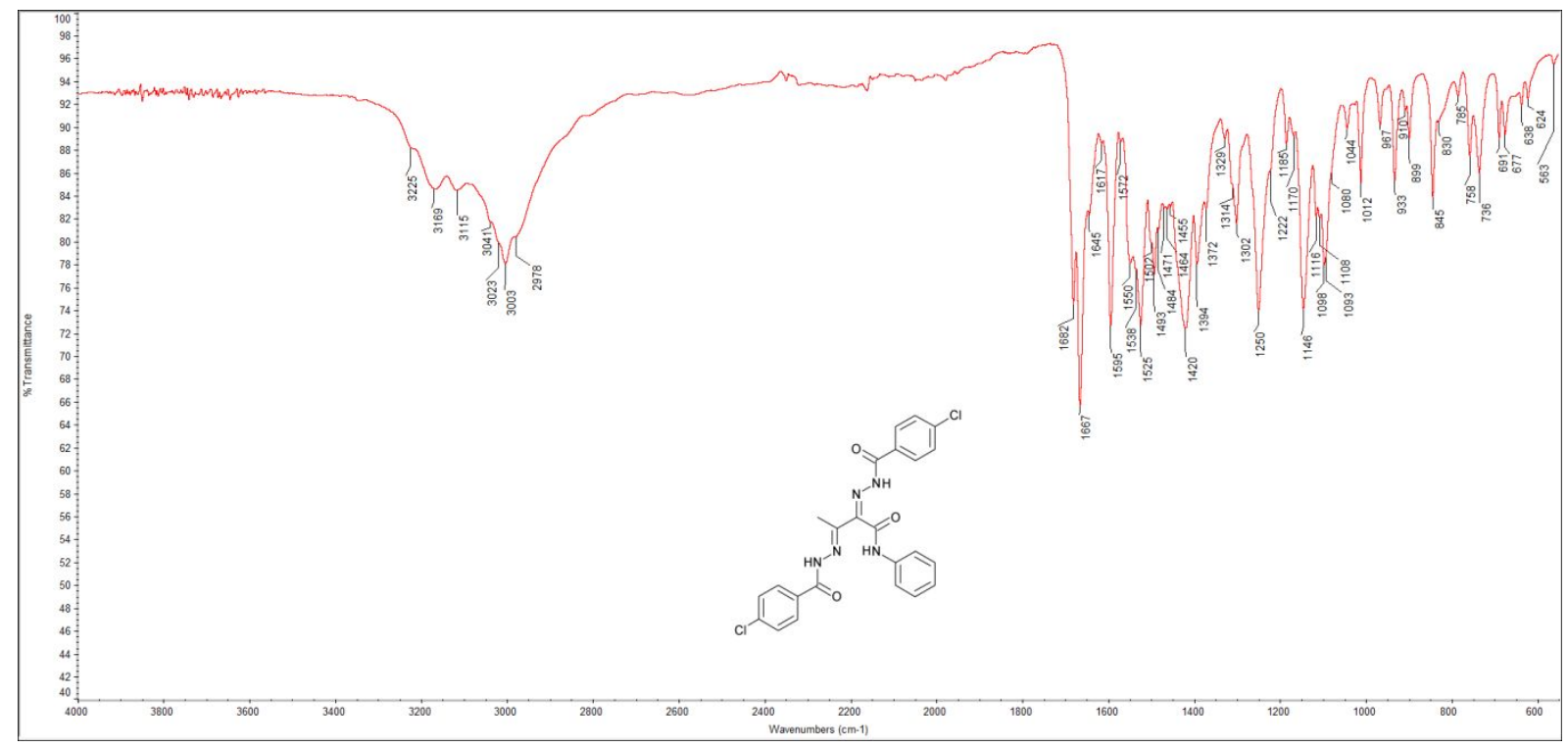

IR spectrum of $\mathbf{C 4}\left(4000-550 \mathrm{~cm}^{-1}\right)$ 


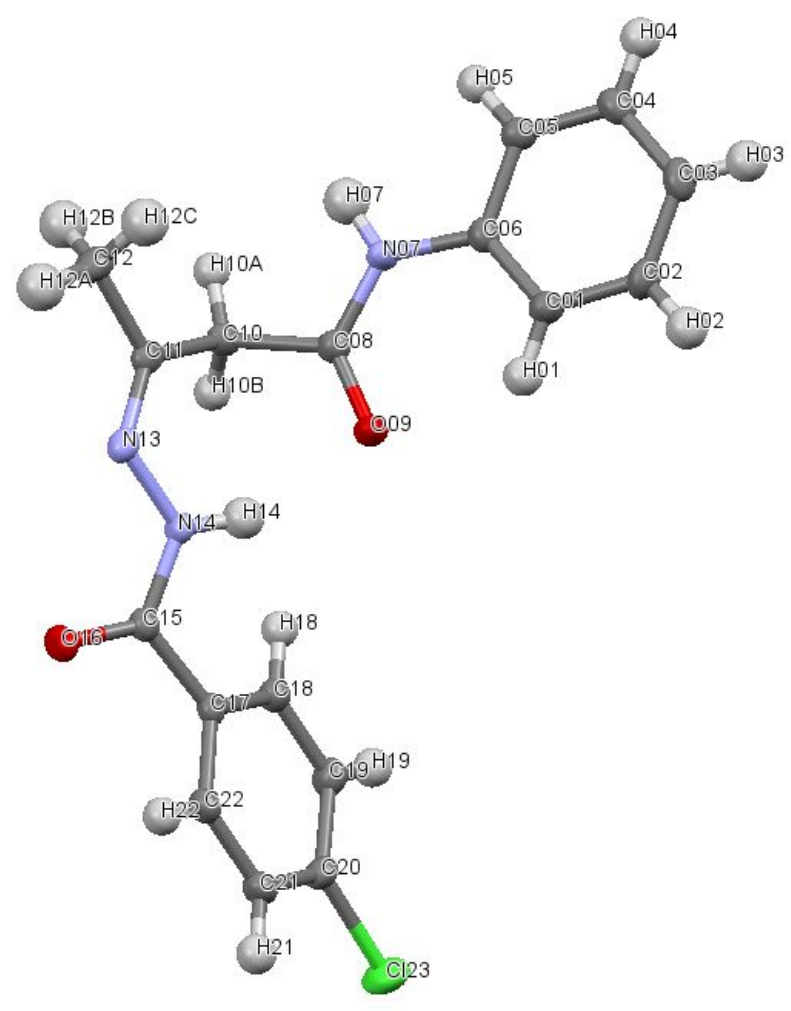

General view of A1B4 molecule. Thermal ellipsoids were set at $50 \%$ probability level. 


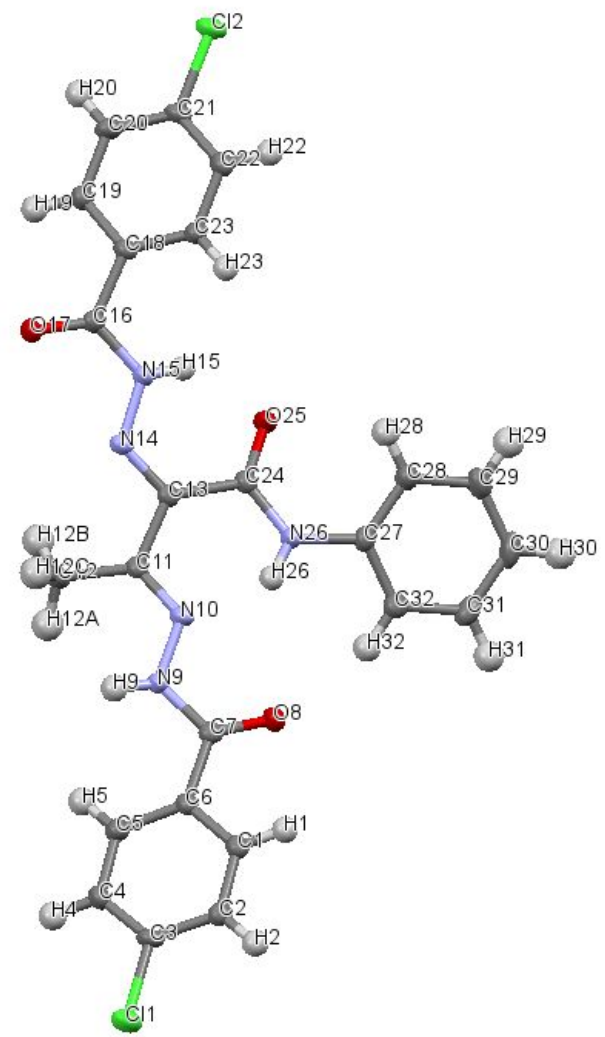

General view of $\mathbf{C 4}$ molecule. Thermal ellipsoids were set at $50 \%$ probability level. 


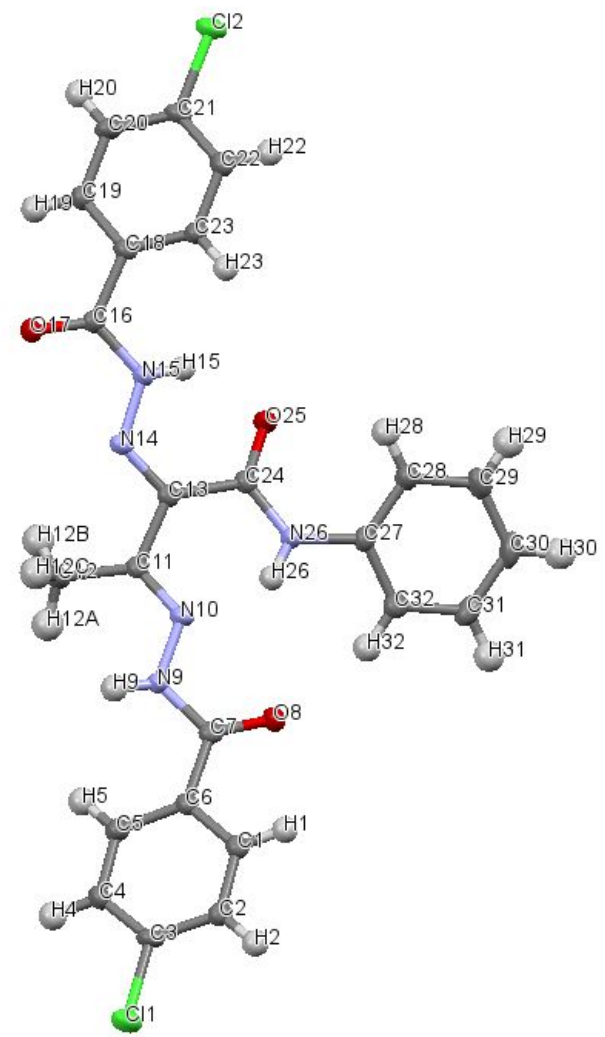

General view of $\mathbf{4}$ molecule. Thermal ellipsoids were set at $50 \%$ probability level. 